
Digitized by the Internet Archive in 2007 with funding from Microsoft Corporation 
$\ln 4$ /913 



\section{GREATER ROME AND \\ GREATER BRITAIN}


HENRY FROWDE, M. $\Lambda$.

TUBLISHEE TO THE UNIVERSITY OF OXFORD LONDON, EDINEURGH, NEW YORK, TORONTO MELBOURNE AND BOMBAY 
GREATER ROME

AND

\section{GREATER BRITAIN}

I)

SIR C. P. LUCAS

k.C.P., K.C.M.G.

OXFORI

A'T 'THE CLARENDON PRESS

1919 



\section{PREFACE}

This book is intended to illustrate, hy comparison with the Roman Empire, some features of the British Empire ats they have appeared to me.

I have to thank Mr. P. E. Matheson, Fellow of New College, for some viluable suggestions and corrections.

$$
\text { (.. P. I. }
$$

Norember, 191:. 



\section{CONTENTS}

CHAPTER I

PIIF:

Romas Temss .

CHAPTER 11

SPACE

CHAPTER III

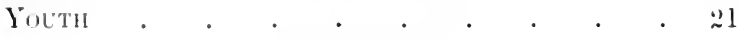

CHAPTER IV

Schesce aNd EMphe: I. Dratace. . . . 32

CHAPTER $P$

Sciesce AND Emptre: II. Whter aNd Medich Scinace . . . . . . . . . 49

CHAPTER VI

The Ispmidal, the Compary, and the State . 72

CHAPTER VII

Class, Colock, and liace . . . . . . 91

CHAPTER VIII

The Natulal and the Artificial . . . 112

CHAPTER IA

The Two Enpres . . . . . . . . . 131

CHAPTER X

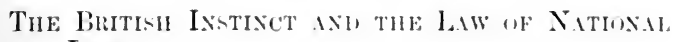
LIYE . . . . . . . . . 156

INDEX . . . . . . . . . 179 



\section{CHAP'TER I}

\section{ROMAN TERIS}

Whex we speak of British latuds and peoples beyond the seas, and of their relation to the Motherland, we nearly alwatys use words which atre of Roman origin. Colon!y, drpentency, pluntetion, prorinere, stute, prossession, dominion, cmpire, all directly or indirectly come from the Romans. (Ine Saxon word, settle with its derivatives, holds a prominent platee in reference to the beginnings of colonies; and, in taking the name of commomerelth, Australlia has in part borrowed from the saxons. But all or nearly all the terms which indicate the political status of Greater Britain and its component parts are a legacy from Rome.

What did the Romans mean by their terms, and what do we mean by them? It will be enough to take the four words, colomy, prorince, dominim, and ('mpire, leaving ont dependency, plantution, and stute, and only noting of possession that possessio in Roman law indicated actual oecupation with intent to retain -for small populations in large lands at useful and suggestive word, and that by the Interpretation Act of 1859 "the expression British possession shill mean any part of Her Majesty's dominions exclusive of the United Kingdom : 
In its etymology the Roman word colonia was equivalent to plantation. The root-meaning of the word was cultivation of the land, and in the later Roman Empire the coloni were a class of smallholders, free men but bound to the soil. ${ }^{1}$ Starting from this root-meaning, colonia like plantation came to indicate in some sort a colony. But, as compared with the English word colony in its ordinary sense, the Roman word colonia implied rather the body of men and women who went out to settle than the place in which they settled; and, so far as place was indicated, it was a town rather than a country, and not so much a new town or settlement as an existing community, into which Roman citizens were drafted, and where in many cases they were allotted lands which had already been in use and of which the former holders were dispossessed. Thus the word colonia implied removal of citizens from an old home to a new, and the derivation of the word indicated agricultural settlement. But otherwise there was no similarity between a Roman colonia and a British colony. There was no dispersion of Romans over a new and wide area, no squatting, no winning of backwood, prairie, or bush. The Roman colonia more often than not contained the element of military occupation. It was rather a permanently established garrison of Romans in the midst of a conquered

1 For the coloni see Pelham's Essays on Roman History (1911), chap. xiii, pp. 275, \&c., The Imperial Domains and the Colonate. 
commmnty than at eolony or settlement in the modern sense.

The etymology of the werel provinein has always been disputed. If the old account of it holds groul, the word implied conquest. But its original meaning was not geographical, for the word implied at charge of business, the duties allotted to ono Roman official or another. I'rovine in, howerer, som came to be applied to the area within which those duties were performed, and to denote this or that district of the Roman Empire ontside Italy. Amonerst the Romans it was used for al country without the limits of Italy, gained to their subjection by conquest.' ' The Roman Empire wis almost entirely the result of conquest, and in 110 sense the outcome of discovery and settlement. Its component parts were dependencies, and those dependencies outside Italy were called provincine.

Dominium in Roman law denoted ownership in its fullest sense; the sum total of rights over property, including slaves. It implied despotism pure and simple. This despotism was openly arowed, when Diocletian took the title of domimus, which carlier Roman emperors had rejected. But the word dominim wats never given, ats the English word dominion has been given, and als protinciu wats given, a geographical meaning. It always indicated purely personal rights.

1 Stokes, Constitution of the British Culonie's in North America and the West Inties, 1783, chap. i, p. 2. 
Imperium denoted the full authority of the State entrusted to an individual. It included all the powers of the State, military, administrative, and judicial, and was limited only by the time for which, and the area within which, those powers could be exercised. The word, therefore, had by no means a purely military connotation, though armed force was never far from Roman hands or Roman minds. The pages of the classics, especially those of post-Augustan writers, show that imperium, like provincia, acquired a geographical as well as a personal meaning, and was often used as equivalent to our English word empire.

The English word colony, like the Latin word colonia, originally indicated the people who emigrated rather than the place to which they emigrated. The place to which they emigrated was rather known as a plantation, and the first beginning of a Colonial Office was a Committee of the Privy Council for the Plantations. 'In strict propriety of speech, colony denotes the people emigrated, and plantation the place in which they are settled.' 1 The word, however, soon came to have a territorial meaning, and the Interpretation Act of 1889 defines a colony as 'any part of Her Majesty's dominions, exclusive of the British islands and of British India'. The modern history of the term colony is interesting. Writing in 1783, Stokes tells us that 'For some time before the Civil War broke

1 Stokes, p. 2. 
out in America, the popular leaters there affected to call the Provincial Establishments, of King's Governments on the eontinent, colonies, instean of provinees, from an opinion they had concerved, that the word province meant a conquered country '. In other words, the Americans were still thinking of colony in the sense of the people rather thim the land, and elid not wish its meaning to be confounded with that of dependeney. But the term colony wass taken to inelude both colonies proper and dependencies, which were the result of ennuest rather than of settlement; and the latest phase is that the colonies proper have rejected the word colomy as implying youth, tuteliges, and dependence, and, with the exception of Newfommlland, have adopted or been given the title of dominions, leaving colonies to indieate the Crown Colonies or semi-Crown Colonies, which are in fact dependencies rather than colonies in the true sense.

The term province, as hats been seen, was, in the earlier days of North American eolonization, often applied to those of the colonies now inchuded in the United States of Americar which hat governors appointed by the Crown, whereas 'a plintation, in which the governor was elected by the inhahi. tants, was ustually ealled a colony, as the colony of Connectient'; but the word has, as a rule, been used without any very speceitic signifieation, with the exception that it has never been 'applied to an

1 Stokes, 1. 3. 
insular government '. ${ }^{1}$ In Canada province is roughly equivalent to state in Australia. In other words it means one or other of the units which form the confederation or Dominion; and, inasmuch as the units which make up the Dominion of Canada are or were more restricted in their powers than those of which the Commonwealth of Australia is composed, the term province may be said to imply less freedom than the term state, although this meaning or implication is, perhaps, more a matter of accident than a suggestion of the original derivation of the Roman provincia.

Dominion, used geographically, may be said to have a double sense. We speak of the whole British Empire as the King's Dominions, the lands which own His Majesty as their lord and master. It is also used in these latter days to denote the groups of self-governing colonies, which seems to involve the paradox that the name which of all others most implies despotism has been given to the most independent parts of the Empire. The origin of the paradox is in Canada. The founders of Canadian confederation, or one of them, Sir John Macdonald, wished to christen the new confederation the Kingdom of Canada; and, when that term was rejected as not being in harmony with American surroundings, the name of dominion was chosen, which seemed nearest akin to Kingdom, and which had previously been given to the colony of Virginia, 
styled the 'Old Dominion'.' Aceordingly the British North Ameriea Aet of 1867 preseribed that the confederating provinces shall form and be one Dominion under the name of Canadat'. The application of the term dominion to a group of selfgoverning colonies maly be defended at follows. The term implies a sovereign lord, and brings the territory in question into direct relation to the sovereign lord. It implies subordination to the Crown, but to the Crown alone, and thereby it climinates subordination to any one or anything else. Thus it maly be construed as at declanation that the self-governing territory is not subordinate to the United Kingdom, but exually with the United Kingdom subordinate to the sovereign lord of both. In other words it mily be held to imply unity of headship, and equality of partuers under the one heall.

It will be noted that dominion in modern piallituee hats more especially come to be used ats the name for a confederation of self-governing colonies, that it grew up side by side with the confederation movement in North Americal and Australasial. But New Zealind, though originally the result of confederiation, was, by Royal l'roclamation of 1907 , formally given the title of dominim, long after it hatd been

1 When King Charles I was executed, the governor of Virminia

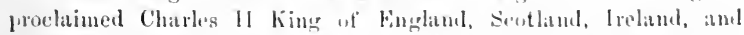
Virginia, and for a time the ams of Virginit were puatereel with those of Fingland, scotland, and l relatud. Hence the title. "The Old Dominions ' arose. Virginia was in litet the first Dominion in the sense in which the torm dominion is now used in the British Fupire. 
unified, and without any further change in its status or composition. Newfoundland, on the other hand, though it takes rank among the self-governing Dominions, still keeps, as a single entity, the name of colony, and is not known as the Dominion of Newfoundland. It is the oldest British colony, and adheres to the name.

Lastly, the term empire is used to include the whole of the British possessions at home and abroad. It is a term which has aroused much prejudice, because it has come to imply military rule to a greater extent than the Roman word imperium, from which it is derived. The King is Emperor of India, but of no other part of his dominions; and when the title of Empress of India was first conferred upon Queen Victoria, there were some in Parliament who raised their voices against it. Those who object to the use of the word empire forget that in past times it was valuable to England, as implying her independence of foreign rulers and not her possession of foreign dependencies. 'The meaning, therefore, of the Legislature, when it uses these terms of Empire and Imperial, and applies them to the realm and Crown of England, is only to assert that our King is equally sovereign and independent within these his dominions, as any emperor is in his empire.' 1 In this sense a statute

1 Blackstone's Commentaries, 1800 ed., Bk. I, cap. 7, vol. i, p. 242. The statute referred to is 24 Henry VIII, cap. 12. See the Oxford English Dictionary, s.v. 
of Henry VIII dechares that 'This realme of England is an Empire'. Even taking empire in its molern and popular sense, there is 110 other single worl which so well covers the immensem improii rompus: it is strictly ateenrate, ats applied to one half of the British possessions; and, if it is less appropriate, ats applied to the other hall, it at least serves to remind us of the complex nature of Greater Britain, and of the historical truth that the present sistem is not the result of peaceful growth alone, but of peace maintinined by adequate protection.

Having thus illustrated the debt which we owe to the Romans for our terminology in regarel to the British possessions overseats and their relations to Great Britain, it is proposed in the following pages to examine some of the leating leatures of the British Empire, and to compare and contratst them with the ehatracteristics of the Rommon Empire, which was the greatest political system of the ancient world. 


\section{CHAPTER II}

\section{SPACE}

Cumate, race, many other factors contribute to the actual present and the coming future of the British Empire; but there is one element in it which, in the sense in which it will be noticed in this chapter, does not often receive as much notice as it deserves. That element is space. What part has space played, and what part is it still playing, in the moulding of the Empire? The question is important in regard to that half of the Empire which contains the self-governing Dominions. If we consider the relations of those Dominions to the United Kingdom, one aspect of the question, as it stands at the present day, is that we have large areas with small populations linked to a small area with a large population.

Assuming for the sake of the argument two countries; one small, the other large; one full, the other empty; and assuming further that all the population of the empty land comes from the well filled small area, then, even if the climate, soil, and general conditions of the two countries are much the same, the mere fact that men and women who have previously lived closely packed together 
are transplanted into great spaces, and that their children are born and bred in great spaces, will produce a somewhat lifferent type of people. The great spatees of the British Empire alrealy have hat much and will have more to sily to its history.

'This element of sparce loses not appeatl to have hat any very appreciable effeet in the Romman Empire. We ane not now eonsidering the total area of that Empire as compraterl with the British Empire, nor the size of any one province ats compared with one of the British overseats Dominions. We are considering the nature of the settement in either case. A large number of Roman men and Roman fimilies emigrated to and settled in the Provinces; their children grew up amid new surromelings and raried aceording to the surromelings; but their lives, chatracters, and physinge do not seem to have been influeneed by spalce to the same extent as those of British emigrants to the self-governing Dominions. The tratition, instinet, and policy of the Romans wats, so fill ats they colonized with their own citizens, rather to fommel new or to reinforee old town eommmities than to settle loosely lange aleas of comntryside; and, wide as was the field in whieh Romin colonies were planted, it consisted entirely of eompluened lanels, the natives of wheh wore eompanatively mumeroms and strong, so that, especially ats they lived in days when fire-arms hat not been invented, even if the homans hat wished to disperse in their settlement, it 
would not have been safe for them to do so. 'A purely rural region, where the people live in villages only, was contrary to Roman interests and traditions.' ${ }^{1}$ This does not mean that there was no country life among the Romans in the provinces. There was country life there, as in Italy, as is shown by Roman villas unearthed on English soil; and the Stateplanted colonies seem in all or most of the provinces to have been supplemented by groups of Roman or Italian traders and farmers, who made their homes among the provincials outside as well as inside existing towns. But the broad fact remains that in Adam Smith's words the Roman colonies 'were all established in conquered provinces, which, in most cases, had been fully inhabited before' ${ }^{2}$; that therefore the Roman Empire was a sphere of rule rather than a sphere of settlement; that the leading feature of Roman colonization was that it consisted in the main of towns and military stations on great highways; and that a large proportion of Roman settlers were soldiers accustomed, as soldiers and ex-soldiers always are, to live in company. Thus it appears that Roman colonization and modern British colonization differed wholly in kind, and that it was not characteristic of Roman colonization to make new homes in large spaces.

${ }^{1}$ Rome, in the Home University Library Series, by W. Warde Fowler, p. 214.

${ }^{2}$ Wealth of Nations, chap. vii, pt. ii : Causes of the prosperity of New Colonies. 
The self-governing Dominions of the British Empire include in their populations other riaces thin the British. This element of spare has, perhaps more than any other, made the Dutch rater in south Africa what it is at the present diay. At home, in the Netherlinds, the Dutch lived elose together in a very small area; and, as their land was straitened and confined, Dutely enterprise found its outlet on the sea. The Dutch went to South Afriea, the Netherlands East India C'ompany" founded a tradding-station at the Calpe, a few Duteh settlers made their permanent homes in South Afriea, some fow of them beeame Boers or farmer, and very gradually settlement straggled inland. Then political canses made for dispersion. Even before the English took the Cape, the Dutch firmers of Grataf Reinet were up in arms against the restrictive rule of the Netherlands East Indial Company, while, after the Cape became a British possession, the Great Trek took plice, and South African Dutchmen went out more and more into space, though it was not empty space, but wilderness tenanted by wild men and wild beasts. Thus, while the story of the Duteh in Holland was a story of towns and ships and seal, the story of the Dutch in South Africal was one of pastomal and hunting life, from which the towns and the sea were eliminated, and where watgons took the place of ships. (ireat spaces have made the Boers, alike in charater and in physique, a distinet type of Dutehmen. 
The case of the French in Canada was not parallel to that of the Dutch in South Africa. France is a much more spacious land than Holland, and on the other hand, French colonization in Canada was so directed and regulated by the government as to keep French settlement continuous on seigniories along the banks of the St. Lawrence, and more especially at or near the three centres of Quebec, Three Rivers, and Montreal. 'The inhabitants of French origin are chiefly distributed along the banks of the St. Lawrence, as far up as Montreal. The land adjacent to this magnificent river exhibits the appearance of a continuous line of villages-a military mode of settlement.' ${ }^{2}$ The French colonization of Canada had in it a touch of Roman settlement. It was in its essence largely military colonization. It was despotically arranged, organized, and held together, in order to keep the land against notable Indian fighters with hostile British colonies behind them. It is true that there were outlying forts and fur stations further west; and, as against the habitants attached to the soil on the seigniories, there grew up a race of wandering voyageurs and coureurs de bois, who were always on the move. But, though explorers and hunters and traders were constantly in evidence, going into and coming back from the wilds, there was no wholesale trekking or dispersion of the population far inland. Moreover,

1 From Appendix C to Lord Durham's Report, 1912 ed., vol. iii, p. 142. 
ats on the one hand the sea diel not dominate the homeland of France and its people to the same extent as it dominated the Netherlands and the Dutch, so, on the other hamel, the Province of Quebec was very fin from being an inland home for the French, such ats Sonth Africal was for the Dutch. Living on the St. Latwrence, the French in Candula always kept in toneh with the seat. In other words, widely different as Camadal was from France, the French settlers in Canaldal were not transported into such wholly different surromelines. as wats the ease with the Duteh in South Africal; and, from the nature and the design of French-Canadian settlement, great spaces did not mould the chatracter of the French-Cinadians, as they moulded the character of the Bocrs in south Africal. It wis when in later times the prairies were reached, and the North-West wats opened for British rather than for French colonists, that space began to tell.

The most purely British of the self-governing Dominions are Newfoundland, Australia, and New Kealand; and of all parts of the British Empire it is in Australia that the effect of space has been most marked. Here, more than anywhere else, the people have been moulded by what the Australian poet has called 'the never ending plains'. At the same time there is this eurions feature in Australian settlement, that a very large proportion of the scanty population of Australia is congregated in towns. Some 35 per cent. of the total population 
is in the six capital cities, all of which are on or near the sea, and more than half the population is in towns of over 5,000 inhabitants. Melbourne and Adelaide account for between 40 and 50 per cent. of the population of Victoria and South Australia respectively. But, over and above the fact that the cities and towns are spread over a very much larger area of ground than is the case in the United Kingdom, it is the country rather than the town which has given and is giving its distinctive character to the coming Australian nation. It is the bush rather than the sea which calls to the Australian, and the future is being fashioned by the back blocks with their widely dispersed and much isolated stations. Those who wish to account for any difference between the English in the United Kingdom and the English in Australia must set it down largely to the influence of space, and those who want to find the exact antipodes to Roman colonization will find it in the story of Australia. Merivale writes that 'the latest conquests of Rome annexed the backwoods of Gaul and Germany in great masses', but he adds that 'even here the colonization of the Romans, and even the occupation of the natives, was confined to certain narrow tracks of internal communication '. 1 What did not exist in the Roman Empire and what does exist in the British Empire is a steady stream of citizens going out from the

${ }^{1}$ History of the Romans under the Empire, 1865 ed., vol. iv, chap. xxxix, pp. 389-90. 
homeland into what the Romans would have ealled the provinces, and there making their new homes on their own lines, scattered and isolated in great spaces.

This element of spatce makes for diversity. There is infinite diversity in the British Empire. Even in that part of it which is comprised in the selfgoverning Dominions, there is the greatest variety of race, language and so forth. In the present connexion we are dealing only with diversity ats the result of space, and the question arises, How far is the Empire likely to lose or to gain in unity aml strength from the filct that great spaces tend to produee different types of the same race?

At first sight it would seem that the more miform in type communities are, the more likely they are to cohere. But, julging from private ats well ats from national life, it maly be questioned whether cohesion is not more likely to arise from supplementing than from duplicating. Within limits there is less probaloility of frietion between those who have points of difference than between those who are in all respects the sime. In the latter cilse there is at best wearisome iteration, in the former case one supplies what the other wants. Wo may find an analogy in the gengralphy of Australiat. Federation or unitication of Australia might well hatve been an easier matter, if the states which make up the Commonwealth hatd differed more in kind from each other, if they had felt more need of 
one another on the ground that each one obviously contributed to the whole what the others had not, instead of being to a very large extent uniform and therefore repeating one another, differing in quantity rather than in quality. Similarly it may fairly be argued that the Empire as a whole gains from the fact that the British race within it, while fundamentally the same, develops in different surroundings different characteristics. A concrete illustration might be found in the late South African war, which was a war in great spaces, and in which the overseas contingents, mounted men habituated to great spaces, admirably supplemented the regular troops from home.

Now, although Canada includes the Rocky Mountains and the Selkirks, New Zealand the New Zealand Alps, while fine mountains are also to be found in Australia and South Africa, yet the great spaces of the self-governing Dominions are in the main not mountain regions, but plains and plateaux. In these Dominions, therefore, space may be said to work its full will upon the incoming British race. On the effects which this cause produces it would be misleading to attempt to generalize, because the conditions of one Dominion differ widely from those of another, and many other elements than space, among them notably climate, contribute to the net result. But if we compare the Australian Englishman, for example, with the home grown product, we find in the former what may be called the open- 
air characteristics of the Linglishman quickened and intensified, and may fairly attribute this result to the influence, direet or indirect, of the bush. We find in the Australian a greater degree, or at any rate more outward signs, of freedom aml equality, greater absence of reserve, greater impatience of restraint and discipline, stronger instinct of race kinship and more spontaneous welcome and hospitality. He is an Englishman who has grown at will with ample elbow room and his not been trinmed and pruned in a confined area and an ordered place. He contributes to the British Empire a citizen of British race but of somewhat different type from the resident in the United Kingdom. It cimnot be doubted that this different type makes for increased vitality of the Empire.

The United Kingdom, being small and thickly peopled, overflows into the spaces of the Dominions, and many years must pass before these spaces are filled. There is no appreciable counter current. Not a few individuals, it is true, from time to time return or eome from the Dominions to the Motherland; South African millionaires bring back their gold, Cinadians find seats in the Honse of Commons, Rhodes scholars go to Oxford ; but the number all told is not large; and, so fiur ats linglind hias received any lasting impress from werseas Englishmen, it has perhaps come mainly from those who have done their life's work in the tropical half of the Empire. and who have always retained actual or potential c: 
hornes in England, with full animus revertendi. Men of the type of retired Indian civil servants, trained in administration, have probably left more mark on life and thought in England than is usually recognized, while the self-governing Dominions have, from the nature of the case, so far been rather engaged in receiving Englishmen and assimilating them to their great spaces than in contributing from their own citizens to the population of the United Kingdom. This means that England is at present leavening the Dominions more than the Dominions are leavening England, but on the other hand, that the proportion of Englishmen of the type which great spaces produce is constantly increasing. There must in the course of history come a time when the lands will be filled and space will cease to tell, but by that time by far the larger number of citizens of British race within the Empire, if the Empire holds together, will be of the type which space has dictated. Therefore, not only in order to appreciate present differences, but also in order to estimate the future, it is well to give some thought to space as one of the factors which is moulding the British Empire, and which was wanting in the Roman Empire. 


\section{CHAP'TER III}

\section{YOI'TH}

The connexion of Englind with India is that of at comparatively modern community of Western type with ()ld World systems and civilization of wholly different origin. The connexion of England with the self-governing Dominions is that of a comparatively old community with young nations in the making, on similar lines to, and of more or less the same material as, the older people. Still confining ourselves for the moment to the latter calse, the relations between the self-governing Dominions and the Mother Country, and having considered the effect of space, let us consider in a sense the effect of time, and regard the relations in question ats relations between youth and age.

Here again there is no analogy to be found in the Roman Empire. 'The Romans ruled and left their mark upon a conquered workl, just als we rule and are leaving our mark upon India. They gave organization, laws, institutions, language, roads, and buildings, but they did not give birth to and reare from subordination to equality young peoples of their own Roman race. So far as they colonized, they colonized, as has been seen, to a large extent in towns, and 
these towns had no separate political existence. They were little off-shoots of Rome and garrisons of Romans; one and another had municipal privileges; but they were never intended to be, and never were, the beginnings of new peoples. A nearer approach to British colonization is to be found in the history of Greece than in that of Rome. The Greek cities were in the fullest sense parents of other Greek cities overseas; but the connexion between the child and the parent was one of sentiment only, the two were entirely independent of one another, the colony as often as not grew to full strength as soon as the mother city, and we look in vain to Greece for a political system including within it states bearing such relations to each other as exist between the self-governing Dominions and the United Kingdom. There is, in fact, no parallel to it in the history of the world. The gradual growth of younger British peoples within and not without the Empire, the maintenance of the connexion between the young and the old, coupled with the continuous development from terms of subordination to terms of practical independence, is peculiar to the British race.

Without attempting here to analyse the causes which have led to existing conditions, or discussing how far the lessons learnt from the American War of Independence and its outcome affected the subsequent course of British colonial history, we can take facts as we find them, and those facts are that one- 
half of the British Empire consists of an old people and young peoples linked together on terms of growing equality.

Peoples are relatively old and young, only so far as they form separate entities. Rome had older buildings and associations than a Roman colony in Gaul or Britain possessed. But a Roman colony was not a people or the mucleus of a people, for it had no political indiviluality apart from Rome. The selfgoverning Dominions of the British Empire, on the other hand, in their relation to the Mother Country, are distinct and separate entities, although both they and the Mother Country are parts of one Empire and under one sovereign. They are rekited as the older and younger members of a family; and this old and very simple analogy of the family supplies the only terms which make the present position as between the Mother Country and the Dominions intelligible.

The Roman State started with the fimmily, and the Roman Empire reproduced the Roman family in so far as the Roman family, like the Roman Empire, was under a despotism, the patria potestas. The British family is on a different model.

In a well ordered British family the soms, while thoy are ehildren, are groverned, protected, trained, and paid for, but always with the direet object of making them, when they come to mans estate, self-dependent and able to stand on their own footing. When grown up, they are helped with capital, if the father has rapital, to start 
them in life; and if there is a family firm, they are given their articles and eventually taken into partnership. They are not expected to pass their lives under the same roof as their parents and in the same household, but to make and be masters of their own separate homes, to create new ties and bring a new strain into the family, of which they none the less remain strong, active, and attached members. For the purpose of the analogy, it will be noted that the object of the father, if he is a wise,

- right-minded man, and the outcome of his family policy, is to promote independence but not complete separation, and by means of independence, not in spite of independence, to retain the life-long allegiance and affection of the children. It will be noted too that, in normal circumstances and in the course of nature, the giving is almost wholly on the part of the father, who finds his quid pro quo in the affection of the children and the knowledge that they recognize, and if need were to come, would be prepared to make good what they owe to him.

This is a sketch of the relations within what we have called a well-ordered family. The key of the whole is continuous adjustment between youth and age, constant concession from the old to the young in the direction of greater freedom, carrying on the son from tutelage to free agency, transforming the parent from a despot into at most a predominant partner, the whole evolution being sound, reasonable, and according to nature. Failures come and 
rifts in the fimily cirele from moluly probnging the parental despotism, in other words from not recognizing in time what is the incvitable result of time, or from cutting the son aldift at tor early an age, in other work from heing premature and trying to forestall time.

It is true that the analogy between individuals and communities fails in that communities do not die like the individual men and women of which they are comprosed. But, just as the father's aim is to reale children who will carry on his nime and perpetuate his work, so it lies with finitful colonizing peoples to rear communities which, even if the worst were to befall, will in some sort uphold the race and the name. This sentiment is expressed in fine language in Lord I urham's Report on Canada. 'Our first duty', he wrote, 'is to secure the wellbeing of our colonial comtrymen: and if in the hidden decrees of that wisdom by which the world is ruled, it is written that these comntries are not for ever to remain portions of the Empire, we owe it to our honour to take good cirre that, when they separate from us, they should not be the only eountries on the American continent in which the Anglo-saxon race shall be found unfit to govern itself.' 1

But Lord Inrham diel not eontomplate dissolution of the Empire. He contemplated contimued life for it and growing strength, by giving greater freedom 
to communities which had outgrown the stage of childhood. It has been said above that in families friction causing or tending to separation arises either from not relaxing authority and making concessions when the time for concessions is due, or from insisting upon the son fending for himself entirely before he is entirely fitted to do so. In the history of the relations between England and the self-governing Dominions, usually but not always at different times and in different cases, the Mother Country has laid herself open to two charges diametrically opposed to each other, the first being the charge of interference, the second the charge of indifference. At the time when Lord Durham wrote, and for the better part of twenty years afterwards, government from Downing Street was the bugbear of the younger peoples of the Empire, and their constant complaint was that they were not allowed to manage their own affairs in their own way without continual interference from home. Then, when responsible government had been granted first to one colony and then to another, although from time to time complaints of interference were still made, the more general feeling was that the Mother Country and its rulers were indifferent to the colonies and would be glad to be rid of them.

The Whigs had been the main supporters of responsible government, and the Whigs were credited with the doctrine, which some at any rate of the leading men among them held, in common with 
Radicals of the type of Richand Cobden, that complete separation of the colonies from the Mother Country was certainly inevitable and probably desirable. The Whigs were logieal men, and separation was held to be the logical result of self-govermment and free trate. But fimily relations are neither logical nor illogical; they are human; and the fomily feeling which thinkers, writers, and politielaus of the Whig sehool considered to be mere sentimentalism, was not mere sentimentalism, but common sense. The Whigs again, while professing democratic principles and fithering demoratic measures, were essentially aristocratic, prim, and orthodox in their polities and their economic views. Hence the new type of somewhat raw democracty which cime into being in the colonies, with it: strong strain of Imperialism and its repudiation of laissez-fuire doetrines, wals not congenial to Whig statesmen. They were, therefore, minded to let the chiblen drift apart, instead of being at pains to alljust the relations of youth and ande. But human nature wats too much for them, and fimily feeling asserted itself in friendly compromise between the young and the old.

Even at the present day, thounh the misehief of interference on the one himd, and of indifference on the other, is far better appreciated than it wats forty or fifty years age, the fimily relation, which is the human element in the Empire, might well be borne more constantly in mind. The criticism is often 
made, if not in public utterance, at any rate in private talk, that England has done much more for the colonies than the colonies for England, that the giving has all been on one side, and so forth. The answer is that, if this is true, it is as it should be. It is right and natural that the giving should be on the parent's side. The quid pro quo comes in the knowledge that the children will, if necessary, take charge of the family in the coming time. As a matter of fact, England has already received substantial help from her children, as the record of the South African war testifies ; and the Dominions are now taking their part in the naval defence of the Empire. But setting aside all considerations of present gain, the fact remains that for the Mother Country to give and the young peoples to receive is in the course of nature.

There are many in England who are apt to be impatient when domestic questions at issue in the United Kingdom are criticized and canvassed overscas, not merely in the Press, but by leading politicians and even in the Legislatures. We read of pronouncements being made or of resolutions being passed on Home Rule, the House of Lords, Women's Franchise, or some other burning question, and we ask what would be said, if the House of Commons were to pass a resolution on the relations of the States or Provinces to the Federations, on the Second Chamber Question, or on any other domestic concern of one or other of the self-governing 
Dominions. We are not ourselves wholly immune from a similar wakness; and from time to time we realize that domentic questions maly easily wear the guise of Imperial questions, as when reciprocity with the United States wats plated before the electors of Camadi, and inpealed to party feeling in Englind. But, assuming that the Dominions are more prone to pass public judgement on the Mother Country than the Mother Comntry on the Dominions, this also is in the eourse of nature. It is the privilege of the young to think that they ean put the world to rights, and to eriticize their elders; and if this holds true in private fimilies, it holds equally true in a family of peoples.

If again we turn to the social relations between the English at home and the English over the seas, harmony in this all-important direction will be promoted and maintained only by bearing in mind the fimily analogy. Young men and women are sensitive, keenly alive to the difference of treatment which either makes them feel that they are tolerated and patronized or makes then feel at home. The same is true of members of young communities. 'The love of British men and women from over the seas for the Old Country will grow cold and turn to resentment if they hear themselves called, and foel themselves treated, as 'colonials', with the implicaltion attached to the word that they are on a different level from their own folk at home. Every man and woman from the self-governing Dominions who 
visits England, goes back at the end of the visit an advocate for or against England. Either when they have come home-for coming to England is still termed coming home-they have found themselves at home, or they have not; and they have found themselves at home in England only if they have been treated on family lines, with all the kindly feeling which is the natural outcome of youth and age making allowance for each other.

There are not a few who will still say with the Whigs of half a century ago that all this talk about the family is nothing more than talk, that these young peoples must go their ways, and the Mother Country go hers, as interest dictates; and there are perhaps more who see in the family analogy the bogy of Imperialism, whatever Imperialism means. The first is supposed to be the view of the plain business man. The second is the view of the man who hates national or racial bombast and exaggeration. The answer to the one is that dealings between the young and the old peoples on family lines are good business; the answer to the other is that such dealings are the most natural thing in the world, opposed to anything that is spurious or affected. The good private business man looks to the future; and, looking to the future, he is glad to strengthen his business by family ties. The good public business man bears in mind the future possibilities of the young peoples, and realizes that separation of these young peoples from the Mother 
Country cannot mean gain to her or to him and may mean grievons loss. 'There is a rational and an irrational Imperialism. Dislike of irrational and blatant Imperialism seems to breed a wongheaded belief that to have a great and growing Empire, and to rejoice in it, is a sinful thing. It is no more sinful than to have a large and growing family ; and pride in it is natural and healthy, when not combined with bluster and vulgill ostentation.

In short the one wise and somel way of looking at the Empire, so far ats it consists of the Mother Comntry and the self-governing Dominions, of weighing its chances and estimating its future, is to argue from the family; and the one way to maintain and strengthen the family feeting and the fimily connexion is to beal in mind that the root of the matter is eontinuous adjustment between youth and ane. 


\section{CHAPTER IV \\ SCIENCE AND EMPIRE}

I. DISTANCE

In all previous eras distance has been the main obstacle to winning and keeping Empires. The great problem which leading nations and their leading men have during the centuries, one after another, set themselves to try to solve, has been how to hold together territories and peoples far removed from one another. Of all Empire builders and holders of the past the Romans were the most successful, and the Romans were pre-eminent in the attention which they paid to communications, in order, as far as possible, to counteract distance. ' The Romans were able for a long time to maintain the obedience of their provinces, and to suppress every attempt at resistance to their authority. This result was mainly due to the efficient military system of the Romans, and to the masterly manner in which they occupied a province, by stationing their legions in strong towns and fortified camps, and by making and maintaining their communications by means of the roads and bridges which they constructed.' The roads were made, it should be noted, primarily

${ }^{1}$ Cornewall Lewis, Gorernment of Dependencies, 1891 ed., p. 127. 
for military purposes, not with the direet purpose of developing the resources of the comtries through which they passed; and soldiers on active service were often employed to make them. for, like the railway battalion in the sudin. and the Italian troops in Erithrea, the Roman legionaries were solilers of the line and Royal Engineers combined, and in the intervals between wars, their commander kept them in hand by employing them on Publie Work-.

But the world which the Romans conquered and held together was the Mediterranean workd, and on the Mediterrancin - it is importint to rememberthey hat for their homeland the central peninsulat. 'All the great Monarehies,'says Batcon, ' the Persians, the Romans (and the like of the Turks), they had not any provinces to the which they needed to demand access through the eomintry of another ; neither had they any long races w narrow angles of territory, which were environed or clisped in with foreign states; but their dominions were continued and entire, and hald thickness and squareness in their orb or contents.' ${ }^{1}$. The Provinces, says Gibbon, 'survounded and enclosed the Mediterranean; and Italy, in the slithe of an immense pommontory, advaneed into the midst of that great lake."

The Roman Empire. in firet, widened ont from Rome ats a centre, mainly on land. From the fortum

Sperleling's pel., vol. vii, p. 52; 'On the true greatness of the Kingdom of Britain.'

"The cline und Fall, chap. ii, 1562 ed., vol. i, p. 154.

1471 
CHAP.

at Rome the roads, strong and solid as their makers, radiated in straight lines to all parts of the Empire. When the sea intervened, it was a more or less adjoining sea, the shores of which had been known and settled for centuries. It is no doubt the case that, having on their hands-for instance-the whole of North Africa from Egypt to Mauretania, or again Britain, which was wholly outside the Mediterranean area, the Romans had in a sense to face the problem of holding and governing Provinces which were only accessible by crossing the sea; and Tacitus writes, with special reference to the East, of 'Provinciae, quae mari dividuntur '. It is also true, as will be noted below, that sea-going in Roman times was a far more dangerous and uncertain process than it is at the present day. But, even when allowance has been made for the difference in scale and kind between the ancient and the modern world, Rome can hardly be said to have handled to any very appreciable extent distant overseas dependencies. For the Romans distances were land distances rather than sea distances, and the Roman Empire could show no Province in relation to Rome even remotely comparable to Australia in its relation to England. It was when Columbus had discovered America, and Europeans acquired great dependencies which were separated from the centre of Government by sea not by land, and by immense oceans not by the Mediterranean Sea or by the English Channel, that distance began

1 Annals, ii. 43. 
to plity its most striking part ats an ohstacle to Empire. There conlel then be no longer any puestion of grandually widening ont from a centre, of contintous atvance, mate grood by prolonging existing roakls, of coasting allung or crossing at long tried inland seal. There wats eomplete remoteness which, as long ats navigation was dependent on wind and tide, that is for three centuries and more, wats only slightly modified by more skilful seamanship and bigger and stronger ships. Distance accordingly Worked its full will on Empires. In some cises it broke them up, and in all, so firl ats the Empires were the products not of eomplest merely but of colonization also, it ealused the white overseats commmities to develop distinct characteristies of their own, inasmuch ats, owing to distance, differences of surroundings, climate, and so forth were not counteracted by close and eonstant contact with the Motherlanel. It was not until after this element of distance hat hat time to leave its mark upon the Empires of the eonquering and colonizing nations of Europe, that the great enemy of distance appeared on the scene in the form of seientifie invention, and steam and telegraphy began gradually to ammihilate space and time.

Now, the great question of the past having been how to hold together peoples living at a great distance from each other, what is the answer to be given to this question at the present daty? 'The answer is that all the signs of the times point to the

$$
\text { D } 2
$$


CHAP.

conclusion that in the days to come the question will cease to exist, that this element of distance will for practical purposes disappear altogether. No man, or, at any rate, no man unskilled in scientific learning, who studies what has been achieved in the past, can set any bounds to scientific achievement in the future. If, say, the cleverest man in Wolfe's army that fought on the Plains of Abraham in 1759 had been told that, had it all taken place a century and a half later, the news of the battle and of Wolfe's death, which occurred before noon on the 13th of September, instead of reaching London, as was actually the case, on the following 17th of October, would probably have been in the London evening papers on the actual day of the battle; and, if Canada had happened to be east instead of west of England, would have been in the English Press early on the same day; and further that he could himself probably have come back to London in a week, he would have treated his informant as a lunatic. How is it possible then, looking back on the past, to come to any other conclusion than that the process of annihilating distance will continue, and-so experience teaches usat accelerated speed?

It is very noticeable how little space most writers and thinkers on political questions have given to the past results and the future possibilities of scientific invention as bearing upon politics. Lord Durham stands out almost alone as an exception to this rule. As his report shows, he contemplated, as far back as 
15:39, a time when the passage from Ileland to Quebec would be a matter of ten or twelve days', and he saw that the completion of sati-fictory communication between Halifix and Quebec, especially if it was by rail, would make the mion of the British North American provinces as they wor in his day, not merely derirable but 'alsolutely neresiary'.' But in nearly every calse the political expert, to all intents and purposes, reasons on the assumption that though human beings change, space and time and the main teatures of the world in whinh they live do not, which may be literally true, hut is practically incorrect.

It was more or less true beforo morlern seience marle itself felt. Consequently, the homans in dealing with their Provinces dealt, so to speak, with a fixed unit. On the other hand, those who arr handling the British Empire are dealing with a fluctuating and uncertiin unit. If, for instanee, we take a Roman colony removed from liome by both land and sea, the distance of liome from Eboracum, the molern York, remained murh the same, in the sense of the time repuired for eoverine the distince, for the whole time that Britain was a Roman Provinee, in other works, for at least there and a half centuries. Once the roals were male in Italy, Gaul, and Britain, any difference in the distance between the two points at one time ats eompland with another depended solely unon the comparative

1912 ad, vol. ii, 1p. 31519. 
military efficiency of the Romans at one time and another, with the resulting state of the roads and the safety or insecurity of the travelling. On the other hand, take Toronto, once called York, in Canada. Though it had been the site of a French fort at an earlier date, as a city it was born about the year 1793, when General Simcoe was LieutenantGovernor of Upper Canada. Its distance from London at the present day, 120 years since it was founded, if measured by the travelling of human beings, is certainly not more than a sixth of what it was in Simcoe's time, and as measured by telegraphic communication has become almost non-existent. Thus the relations between London and Toronto have been constantly changing, always, it is true, in the same direction, that of greater proximity, but none the less changing, and, therefore, the problem of Empire has been constantly changing likewise.

On the other hand, while the gradual diminution of distance makes a modern Empire, as compared with an Empire of the past, a more fluctuating and less constant unit, the improved and improving communication, which produces as its direct result this element of change, is in itself a more constant and certain factor than the communication which existed in past times. The importance of steam communication, especially on the sea, consists not only in ensuring greater speed, but also in ensuring greater regularity. A mail steamer crossing the Atlantic meets with 
heary weather. She arrives at her port of destination possibly a good many hours behind time. But tho delay and uncertainty is as nothing comprared with communication by sailing-ships. The historian of' 'the Romans under the Empire' tells us that, before the diys of steam, in fair seasons, and with fitir winds, the navigation of the ancients, emolueted hy oars and satils, was speedier than our own, but that, on the other hand, storn or aldrerse winds prolonged the royages almost indefinitely; while in winter. time the sea wats closed. 'The communieation between Italy and Spain by water was interrupted in the middle of Norember and only recommenced in March.' Now that steamers have taken the place of sailing-ships, certinty has been substituted for uncertainty ; steam is the master, not the wind or the sea. Thus it maly be summed up that the Romans were called upon to counteract permanently fixed distances by more or less uncertain methods. The English are dealing with eontinually changing distances by more or less assured and constant, though always quickening, machinery.

Telegraphy deserves special notice in connexion with the sulject of eommunications and Empire. The speed of the post wats in limman times, and is in our own, the speed of the fistest travelling human being. A man travels fister now than he did in Roman times, becallse he travels on lame of seat by

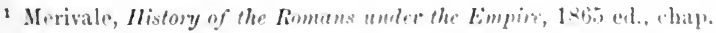
xxxix, vol. iv, pp. $390-1$. 
steam, instead of on or behind horses and in sailingships. A post is carried faster for the same reason. But whether the letters are carried by relays of mounted couriers, as among the Persians and the Romans, or by railways, the letter travels no faster than man, assuming the man to have sufficient endurance. Letters are sent from London, via Brindisi, to catch the mail steamers for India and Australia at Port Said, but a man can travel by the same route and arrive in the same time. Thus, if we take steam alone, although steam communication is from one point of view wholly different in kind from communication by horses on land and sailingships on sea, from another point of view it differs not so much in kind as in degree, for the speed of posts in relation to men has remained constant, being as a matter of fact one and the same for letters and for human beings. But when we come to telegraphy, we have reached a species of communication which is ever so much more remote than steam from old-world communication, for it bears no relation whatever to the travelling speed of a human being. In other words, modern science has not merely accelerated and regularized communication, measured, so to speak, by the standard of human beings, but has evolved a new species of communication in which the standard of the human being has disappeared altogether.

What further developments may be in store in this direction; what the conquest of the air, which 
is now beginning, may bring to birth; and whether the human standarel of communication may in generations to come be levelled up towards the nonhuman or telegraphic standiud, must be left either to pure speculation or to the forecast of the greatest scientific men. We can be content for the present purpose with the phin and patent fiat that distance is constantly growing less, and with the inevitable conchusion that the great Empire problem of the past, which was a problem of distance, will cease to exist.

What will be the result? The result, it seems, will bo that, while the old standing ditlienlty of Empire will be removed, the agency which hats removed or is removing it, will create, and alrealy is creating, new difficulties, to tax the brans of statesmen and the patience of citizens. Let us take elimination of distance as affecting, firstly, the relaltions between the Self-Governing Dominions and the Mother Comntry, secondly, the internal relations of the Empire as a whole, and, thirdly, the relations. between the Empire and the ontside world.

It has already heen pointerl out that elimination of distance is coming too late in the day to nentralize the effect which distance has preduced in making more or less separate nations. The Selt-Governing Dominions have taken their present form and shipe beeause of distance. They were sert to govern themselves becamse the Mother Comntry, being distant, could not otherwise satisfictorily provide for their 
government. Before the modern doctrine of responsible government was propounded and put into practice, it was suggested that the British overseas communities might send representatives to the British Parliament. This suggestion was ridiculed by Edmund Burke as being impracticable on the ground of distance. It would not be impracticable now to anything like the same extent, and in one or two generations will probably not be impracticable at all. But, on the other hand, if representatives were sent to an Imperial Parliament at the present day, they would come as representing distinct nations which distance has brought into existence. In other words, their presence in England would not now be, as it would have been in Burke's time, in lieu of self-government in the Dominions, but additional to and supplementing self-government. Moreover, again as the result of distance working for another century and a half since Burke wrote, the representatives, assuming them to be of the same British race, would yet be more or less distinct types of the race. No doubt the diminution of distance is modifying and will in a growing degree modify the divergence, but still we have to reckon with the broad fact that even when distance has been eliminated, the results of distance will endure.

It has been suggested in a previous chapter that the diversity in the British Provinces of the British Empire which great spaces have promoted, may eventually be found to be rather a source of strength 
than of weakness, making for union, not for discorrl. Conversoly, the elimination of distance may not be and probably will not be wholly at gain. Relations can see too much of each other, and fimiliarity is said to breed contempt. Nore intimate and everyday knowledere of one another means, or may mean, greater emphasis on the diflerences which have been produced by diflerent surromelings. Wery ehango in human relations, howerer, has its bad ats woll as its good side, and it camnot serionsly be doubted that the net result of the elimination of distance must be to promote liamony between Great Britain and the Self-(ioverning l)ominions. Increasedeoming and going must mean better understanding; the vacant spares will be filled by British citizens less and less moulded by distance, and, therefore, not increasing but diminishing the divergence; while the dangers of proximity which arise from facilities for interference, are now practically non-existent as far as regards the self-foverning Dominions, owing to the fict that distance has done its work in ereating distinct peoples and demonstrating the futility and unwisdom of one people interfering in the domestic concerns of another.

If, however, we tum to consider the internal relations of the Empire as a whole, it is not possible to feel equal eontidence as to the results of elimination of distance. The faret must be fared that while it probably makes for better relations between the white citizens of the Empire, it tends to widen 
the gulf between the white British citizens of the Self-Governing Dominions, and the coloured British citizens of India and the Crown Colonies. The closer India comes to British North America, Australasia, and South Africa, the more prominent and aggressive becomes the colour problem. We should hear little of it, were these lands now as remote from each other as they were 100 years ago, and even now we should hear less of it, were Canada and Australia as thickly populated with white men and women as is the United Kingdom. But, as things are, the growing proximity of white men's lands with empty spaces to lands over-populated with coloured men, tends gravely to emphasize the fact, to which further reference will be made in a later chapter, that the British Empire is two Empires in one, and to make the instinct of race run counter to the bond of citizenship. The Romans have given us no guidance in this matter, for they do not seem to have been troubled to an appreciable extent by any colour difficulty, and, at any rate, if they had a problem of the kind, they did not find it accentuated by lessening of distance.

This difficulty is mainly a difficulty as between the different overseas Provinces, and does not immediately concern the Mother Country, except so far as it is vital to the whole Empire. Let us therefore go on to note what effect the growing elimination of distance has on the relations between the United Kingdom and the Tropical possessions of 
the Crown. Beyond question constant and speedy communication in the matin fitrilitates andministrat tion and strengthens control, but at the sime time it also fictilitates interference, by the Home Government with the men on the spot: ly Parlianent. the general publie, and the I'ress, with the Government; and so fiur it tends to weaken the executive, to militate against continuity which is vital for the keeping of an Empire. It grives rise to more knowledge of one kind and to less of another. There is firr more groing to and fro in the present than there was in the past, and a much larger proportion of Englishmen know something of India than was the case al entury ago. But, on the other hamd, the Englishmen set to rule or to trate in India make Indial less of a home than in hyonome days, when visits to England were neeessarily few and at long intervals of years. The tendency to come hack constantly during the course of service is stronger than it was, beeause the opportunities of returning are greater ; and the English in Indial, therefore, are less of India than they were, in the sense of passing their working lives mblokenly amid Indian sme roundings. Nor, again, are the multiplied visits to England of the King's colomed Indian subjects, anel the consequently growing fimiliarity of East Indians with the Englishman at home, all at gain to them or to us. In any case, if we allow that quicker and more constant eommunieation between East and West, or between Afriea and England, is not 
only inevitable but on the whole beneficial, we must at the same time allow that it is making the problem of Empire infinitely more complicated.

As distance diminishes within the Empire, so it diminishes at the same rate between any or all parts of the Empire and the outside world. What is the result? The Self-Governing Dominions are being brought closer to England and to each other, but pari passu they are being brought closer to foreign nations. It would at first sight seem that constant contact between two different races or nationalities might tend to weaken the instinct of race; but that instinct is so strong that closer contact and therefore sharper contrast may possibly rather intensify it. It may be said, perhaps, with more confidence that the elimination of distance will tend on the whole to strengthen the race instinct, than that this tendency will necessarily make for unity in the Empire. Strong race feeling may make white citizens within the Empire range themselves with white men outside the Empire as against coloured fellow-citizens within the Empire, and conversely the latter may turn towards coloured peoples who do not share their citizenship in preference to white British peoples who ignore it as a bond of sympathy or brotherhood. Take again the white races only, so far as the white men in the Self-Governing Dominions are not British, improved communication which brings the French Canadians closer not only to England but to their old mother-land France, 
maty make them not less hut mone frenels, and so with the llutehmen in Somth Alrieat. Or take ence mene the bitish ratee alone. Australiat is being brought eloser to the Lnited states ats well ats to England, at young British nation, to another kindred nation young as eompaned with England and correspondingly attratetive in valroms was.

Assume, howerere, that elimination of dintance will not be a dissolving filetor als regalde the British Empire, soldicrs and satilors must still be atsked what eflect it will halve in cease of wall. 'The a latyman it would seem that, inatsmuch as the British Empire is and hats been specially valuerable in virtue of being so widely spread, the concentration which will be the result of eliminating distance will make it easier to defend in ealse of attalck, notwithstanding that the possible comemies on all sidles are being brought closer to our doors.

One notable result of the lessening of distance for the British Empire in particular, and for the world in general, is what maly be called the rise of the South. It is through the lessening and climination of distance, and only throngh it, that the lands in the Sonthern Seas, so remote fiom the main centres of the worlel, are at length beginning to take their part in making history. 'The bist led the way; civilization moved West and North; then further West aleross the Athantic to the New World; and now fir in the southern hemisphere, the Argentine Republic, South Africa, and above 
all Australasia, are beginning to loom large on the horizon. Of the three groups of British Self-Governing Dominions two are in the South, and the rise of the South, as distance decreases, peculiarly concerns Great Britain and her Empire.

In this chapter, as in the whole little book, no pretence is made to elaborate solutions of the great problems of the future. It is only desired to suggest what those problems may be and how they have arisen or are arising. As regards the special subject of this chapter, distance and Empire, it seems safe to sum up; that science is determining and will determine the fate and the kind of Empires: that science is removing what has been the greatest of all impediments to Empires in the past, and in turn is creating new difficulties: and that the Empires of the past, in the absence of modern science, presented a more difficult problem in the sense that the one great obstacle to a solution was more overwhelming, but an easier problem in the sense that the conditions were far less complex. 


\section{CIIAPTER V}

\section{SCIENCL ANI) EMPIRE}

\section{(ii) W.ITER I.ND MEICIL, SUIE.NCE}

Ix the list chapter no reference was mate to canals als agents in eounteracting distance, because canals, being merely water roals instead of limel roads, do not necessarily imply stem and electricity. Yet, to take the most obvious instinces, the Suez Canal is, and the Panamal Camal, when completed, will be, of the utmost importince in bringing different parts of the world eloser together. Reference has been milde above to the fiact that the component parts of the British Empire are, by the agency of science, being brought eloser to foreign nations ats well als to one another. One most important result of the Panama Canal will be to hring Australia and Now Zealind nearer by sea to the great ports on the Eistern coast of the Uniterl States than to Great Britain.

Canals of one kind or another, in the sense of large ditehes or waterways dug out between one water and another, are presumal,ly ats old at humin activity in any form. In China and Eeypt, for instance, there were cimals from very early dates, for transport ats well als for irrigation. The eanil 
from the Nile to the Red Sea, connecting the Red Sea and the Mediterranean, which was finally opened by Ptolemy Philadelphus about two and a half centuries B. C., had been begun about 600 years B.c. and possibly much earlier. The story told us by Herodotus of Xerxes' canal through the peninsula of Mount Athos-'velificatus Athos'-is a good instance of an ancient ship canal; and a canal through the Isthmus of Corinth is said to have been contemplated by Periander about 600 B.c. as well as later by Caesar and by Nero.

But the Romans, who set an example to all time of road- and bridge-making and of bringing drinking water on aqueducts, do not appear to have made conspicuous use of canals for what may be called Imperial purposes. Mommsen tells us that Ptolemy's canal was kept open and navigable in Roman times, but that it 'was in the Roman period only of secondary rank, employed chiefly perhaps for the conveyance of blocks of marble and porphyry from the Egyptian east coast to the Mediterranean'. From Tacitus we learn that one of the Roman generals in Nero's time, in order to give his soldiers something to do in time of peace, designed a canal to connect the Moselle and the Saone, 'so that troops crossing the sea and then conveyed on the Rhone and Arar (Saone) might sail by this canal into the Moselle and the Rhine, and thence to the

'The Provinces of the Roman Empire, English translation, vol. ii, 1. 297. 
ocean. Thus the diffieulties of the route being removed, there would be communication for ships between the shores of the West and of the North." But this camal wats never male; and the first great artificial water communications carried out in France date from the seventeenth century, the Briare camal, connecting the Loire and the seine, and the Lamgutedoe cinal, or Cenul du Midl, 140 miles long, linking the Gulf of Lyons to the Baty of Biseay.

The Romans seem to have repaired and improved existing camals, especially in Lgypt, but the canals which were entirely their own work were mainly local canals. There was, for instance, the Fossat Mariana at the mouth of the Rhone, the handiwork of the Republican general, Marius. Augustus made a canal in connexion with his great naval station at Ravenna. Tiucitus tells us of another Roman general who kept his soldiers employed in digging "a camal of 23 miles in length between the Rhine and the Meuse, as a means of avoiding the uncertain perils of the ocean '? This, according to the commentator, was a canal near the coast of Holliund, possibly in the neighbourhood of Leyden, and its object was not so much to filcilitite transport ils to prevent inmulation of the land by the seat. There were again in our wwn fen listricts and lincolnshire the Caer Dyke and the lioss Dyke, 40 miles long

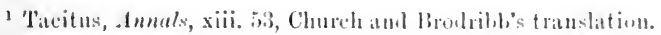

2 Annals, xi. 20, Church and Brochibhis trituslition. See the note to the passige. 
and $10 \frac{1}{2}$ miles long respectively; but these too were local waterways, and it may safely be said that canals for purposes of long distance traffic did not figure to any appreciable extent in the organization of the Roman Empire. The reason was twofold. In the first place, communications with the Romans were primarily a military matter, and canals would have been of little use to them for the purpose of moving their legions promptly from one place to another. In the second place, neither the Romans, nor any of the ancient peoples, seem to have had any idea of using locks to adjust differences of level in water communication. Locks hardly imply a very advanced stage of engineering knowledge, and it seems extraordinary that they only came into use in modern times. To what extent they have been utilized in the British Empire with the aid of modern machinery can be realized by those who have seen the traffic at the Sault Ste Marie between Lake Superior and Lake Huron, or at home have noted the Manchester ship canal, described in 1896 as 'the first large ship canal which has been constructed with locks, raising the vessels $60 \frac{1}{2}$ feet, and transporting them inland, and thereby converting an inland city into a seaport'.'

Inland water communication in the British Empire has found its fullest expression in Canada. The Roman Empire contained no Province which could be set side by side with Canada in this respect.

${ }^{1}$ Harcourt's Rivers and Canals, 1896, vol. ii, p. 592. 
In Cantala, before the days of railways, roughly speaking down to the midhle of the nineteenth century, communication wats by water rather tham by land, and inland cantls have played, and still play, a notibly great part in the history of the Dominion. They have been used at once to supplement and correct the natural waterwitys, and to shorten distance. There are 7is miles of cimal correcting the great waterwaly between Lake superion and the Gulf of St. Lawrence, and some to locks, Lake Superior being 600 feet above the level of the seat. The camal which would have the greatest effect in shortening distance wats talked of in Lord Durham's time and before, but is still for the future. This is the Georgian Bay calnal, which would link Lake Huron to the St. Lawrence at Montreal, by following the Ottawal river and the old French route to the West. Camadian camals are mostly of no great length. They begin with short cuts on the St. Lawwence, above Montreal, constructed, it should be noted, in the Roman spirit, for military purposes, when a military man, General Haldimand, wats Governor; and in the Ridean eanal, which wats carried wut at a later date, 126 miles long, from Ottawa to Kingsten, we have again a work on Roman lines, in that it was male for purcly military reasons, an Imperial unclertaking paid for by the Imperial Government. Possibly, if the Romans had found their way to Camaklat, Eastern Camada being so fishioned that its natural highway's are water 
CHAP.

highways, they might have turned their attention to communication by water rather than by land, and might have invented locks. But they would have had to leaven their military instincts with a larger amount of commercial initiative than appears in their history, to have constructed, for instance, the 27 miles of Welland canal for the purpose of carrying not troops and their provisions but heavy merchandise past the falls of Niagara. That canal, too, though not in its present form, was, like the Rideau canal, anterior to railways. Its present form, and the great canals of modern days, we owe to steam in the making, and they carry steamers when made.

Now, leaving altogether the subject of communication, let us ask what science contributed in other directions to the Roman Empire, and how far it has transformed and is likely still farther to transform our own Empire. It may be laid down in general terms that, over and above communication, the main Empire work of science is to make habitable places more habitable and unhabitable places habitable. But, before taking this point, it is necessary to say a word as to the influence of science in causing the transplantation of human beings, not only directly by easier communications, but also indirectly, as the result of scientific inventions.

Ages before the Romans came to mould the world, stupendous works, some of public utility, some apparently little better than private freaks, were made 
by human lands, and ate standing, like the Pyra. mils, to astonish us still, but it womld be hand to saly how firr they were the result of serentific invention and how far the onteome of molimited application of brute foree, at a time when derpotiom and slavery were in their most naked stares. Sieienee or force must have temporarily peopled particular. localities, only to be left doreliet again; but it is impossible to reason firom these very far balek ditys as from the records of the eomparatively modern Romin Empire.

It ean be taken that in historical times, in the ordinary course, the ancients, like the moderns, found at this or that plater one metal or another of commereial value and liad learnt how to smelt and to work it. The finding attrateded population to the spot; means were devised for providine the newcomers aldeyuately with food and water ; and when the mines were exhausted, so fial ats seience then reached, the population moved away. 'That process has presmmably been common to all ares, ats well ats the process of this or that town alequiring or losing, from one local cause or another, a particular industry. But modern invention and modern applinnees in machinery must hatre vistly increatsed the seale on which, and the rate at which, the populating and depopulating have taken platere. Horeover, the fitet that mines in the lioman Empire were treated wholly or mainly as state property and were leased by the Govormment, maly have had to some extent 
the effect of preventing great rushes of adventurers eager to peg out claims. At any rate, we do not read of any Kimberley or Johannesburg or Kalgoorlie or Dawson City springing up in the Roman Empire. Ruins of what seem to have been considerable mining centres exist in Eastern Egypt near the coast of the Red Sea. But the remains prove that here the Romans were in no sense pioneers : they only continued existing workings. Moreover, these mining townships or cantonments were situated on or near a caravan route from the Red Sea to the Nile, in a fine strategic position commanding the water supply of the district, which points to the conclusion that population may have been attracted on other grounds than mining alone.

Nor again do we find any analogy in the Roman Empire to the effect upon the working population which the substitution of machinery for hand labour has produced in modern times. For instance, in the twenties and thirties of the last century there was a large stream of emigration to British North America from the North of England and the South of Scotland. One great cause of the movement was the distress which arose among the weavers of Lancashire, Lanark, and Renfrew in consequence of the substitution of machinery for hand labour. This was a case in which scientific invention repelled population and led to its being transplanted to America.

We read that latifundia perdidere Italiam, that the economic effect of large estates worked by slave 
libbour was to repopulate some districts of angienltural Italy, to drive ont the suall fireholder al peasant farmer. Whe real ton of the cities of the Roman Empire, or, at any latte, of liome itself, with its superior attratctons, elepleting the commery just as Lomber and the enceat mban rentres do at the present diy ; but there deres nut seem to be evidence that the movement of population in the Roman Empire wats, to any appreciable extent, atfected by seientific invention.

A German amthority has been quoted to the eflect that 'most of the realms of the ancient Roman Empire had better enmexions and ronditions than ever afterwarels or even nuw ${ }^{1}$ If this is true, how far was it the result of scientitic knowledge anome the liomins, and how far diel they apply sedence to making the habitable partis of their Emprite more habitable, and unhabitable plitees hatbitable:" Allowance must be male not only for the results of human injury or neglect, but also for ehanges which since their daty nature has wrought or maty hatre wrought in lands or loealities which they tamed and eivilized. The sear, for instance, hats left harvennal inland and derelict. Giblen writes of it, "The gradual retreat of the seat hats left the modern eity at the distance of form miles from the Adriatie, and ats early ats the fifth on sixth century of the chri-tian

1 Heinrich stephan as quoled in Frielliander's liomen ligie ame

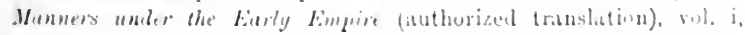
1. $26 s$. 
era the port of Augustus was converted into pleasant orchards, and a lonely grove of pines covered the ground where the Roman fleet once rode at anchor.' 1 Climate again may have changed in one district or another, apart from the undoing of man. It must also be borne in mind that, though the Roman Empire eventually included no doubt much that might be classed comparatively as bush or backwood, the proportion was as nothing compared with the wild lands overseas which the English have taken in hand. Yet the Romans had wide scope for applying such scientific knowledge as they possessed, and they possessed a great deal. Their noble bridges and aqueducts, as well as their roads, testify that they were good engineers. They knew how to drain lands for agriculture and for sanitation. They made embankments and dykes and reclaimed from the sea. In various parts of what was their Empire the ground which they made was subsequently lost and even now has not been recovered. But the same is true of countries which they never administered. In Ceylon, for instance, the English are painfully restoring the great tanks and watercourses which once irrigated and made fruitful districts that afterwards relapsed into jungle. All the world over, much of the good work of the past has been lost; but taking the Roman Empire as the most highly organized system of the ancient world in historical times, there does not seem to have been

${ }^{1}$ Chap. xxx, 1862 ed., vol. iv, p. 42. 
what has marked molern history and colonization, at any rate since stean and electricity have heen brought inte play, a comstant onwarel movenent of science, a continual perfecting of ohl inventions. and series of new disesseries. What the Romans knew, they knew well; and what they disl, they diel well; but after all their knowledere wats amparatively limited and their ands were eompratratively limited also.

Romaln aims were limited for two reasons alrealy given. The first reason wats that, taking their history as a whole and their Empire ats a whole, with the Romans military considerations were paramomt. This does not mean that their Empire was purely the outeome of deliberate conquent and annexation on a preconceived plan. They were drawn on in the path of Empire, ats we hatve been drawn on, by foree of eireumstances. Nor andin dres it meam that all the Provinces wore simply held down by military gamrisuns. On the contrang, in the Provinces not on the frontiers of the Empire, after the time of Augustus, as a rule no legions were puartered; and the letters of Cicero at one time, of l'liny at another, show that economide and social puestions reorived ats much attention as, or more tham, military matters. Merehimts, traters, finaneiers, amel spectulators of all kinds, were coming and going and prerating throughout the lioman Empire ats thromgh ours; and the Govermment hald its eye on commeree, on national and provincial sources and methods of 
production. But it seems true to say that, while the Romans largely developed, partially colonized, wonderfully assimilated, and in some cases, or at some periods, effectively administered the countries which they had conquered, their ultimate object was to secure and maintain their tenure. Their military strength and their comparative toleration made for peace and consequently for development, and so did their military roads and their strongly guarded towns; while men of the type of Agricola in Britain-a soldier in a frontier Province-had in full measure the desire and the capacity to be good and workmanlike governors, to study the interests of the ruled as well as the rulers. But, none the less, it may fairly be said that development was more of a by-product with the Romans than it is with us. 'It was no part of the policy of the conquerors', writes Merivale, 'to facilitate the intercourse of the natives of the interior.' 1 It is true that our primary object in India is to hold India; but development of India, not merely for its advantages to England, but at least as much for the benefit of India and the Indians, is the aim of those who have charge of it. India is less exclusively regarded from a military point of view than would have been the case, had it been a Roman Province. It is less a piece on a military chess-board than it would have been in Roman hands.

1 History of the Romans under the Empire, vol. iv, chap. xxxix, p. 400 . 
The second reason was that the Romans did not deal or attempt to deal with great areats of territory to the same extent and in the same sense as modern nations, the English in particular. This was partly becallse the areats were als a matter of fact infinitely smaller, one liritish Province alone (Caniddi) being apparently about double the size of the whole Roman Empire, partly becallse in the areas which the Romans ruled, their metier was, ats hat been seen, not to spreakl, hut to concentrate, again largely because they were first and foremost suldiers. The Roman Wall in Northumberland seems to illustrate the Imperial poliey of Rome. The remains of it stand after all the eenturies to tell us how strongly the Romans built, how well they did the work to which they put their hamels. But why wis it built? To give security, to enable them to hold what they hade, and to hold it as a military people. Walls are made to keep some human beings in and other human beings out. They do not facilitate but obstruct coming and going. They are not means of development, they are obstacles to develepment exeept so far as they give security to the enclosed area. The Roman Wall meant a preserve for barbariom ontside it. We may find some rough analogy, perhaps, on the northern frontior of India, where various

'Gibbon at the ent of his first chatpter salys that the Roman Finpire in the time of the Antonines "was supluseml to contain ahose sixteen hundred thousand square miles', but his note to the gasiage shows that he distrusted the ligures. Cimalis is gisen an area of nearly 3 million square miles. 
CHAP.

native States are secluded from the indiscriminate coming and going of white men; and in lands where British supremacy has been assured, in South or East Africa, for instance, or in New Zealand, native reserves have been established to safeguard the interests of the indigenous races. But, taken as a whole, British trade and colonization have known no limits. The policy has not been that of the Roman Wall.

The Roman aqueducts can be taken as evidence of Roman scientific knowledge and engineering skill. If the Romans did not make much use of canals for long distance traffic, they were past masters in bringing water for drinking purposes. How far in this matter did they, as the saying is, think and work Imperially? How far did they make habitable places more habitable, or unhabitable places habitable? The answer seems to be that they achieved the first object more than the second, that they handled mainly, though not exclusively, places already populated, and colonized largely in existing towns. By their aqueducts they more often improved than created. We should find it difficult to match in strength and beauty the magnificent aqueducts which supplied Rome itself with water, or the Pont du Gard which supplied Nismes, and whose 'lightness of structure, combined with such prodigious durability, produces the strongest sense of science and self-reliant power in the men who designed it'. 'None but Romans', added John 
Addington Symonds, "could have built such a monument and have set it in such a place." But it was built to supply at town in one of the most civilized parts of the Roman Empire, hatrel hy l'rovence which specially alpropriaten to it-elf the generie term of 'Provincial. The records of the Lomam Empire would not provide a paralled to the watersupply of Kalgoorlie in Wentern Australial. That is an instance of making a place fitr remote in an outlying Province of the Empire, not on a trateroute, not on the fringe of but in the heart of the desert, not merely habitable but the scene of a considerable modern city with the latest convenientess and appliances, by bringing water from the Mundaring reservoir, which even Rome might have envienl, in pipes for $3 ., 0)$ miles.

Again, so fin as their anpeducts and water-comrece served agricultural purposes, irrigating firlels and not merely supplying finntains and haths in cities, the Romans seem rathere to have improved and supplemented existing conditions than to have erolved something wholly new. They are not associated to the same extent as Ealstern peoples with large irrigittion schemes, though a quotation to the contrinly is given below. ${ }^{2}$ Augustus, who kept the Province of Egypt in his own hamds, took ware that the cantal system of the conntry was repaited and completerl, and Mommsen writes that the Reman Government

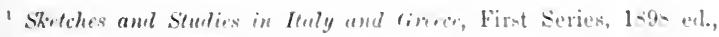
chapter on 'Ohl Towns of l'rovence', p. 76.

I. ti.i. 
applied itself more zealously to the elevation of agriculture in Egypt than anywhere else '; ${ }^{1}$ but notwithstanding, Roman engineers do not seem to have left any very distinctive mark upon the land of the Nile and now of the Assouan dam. Nor did they anywhere, in the matter of irrigation, rival the triumphs of British engineers and the British Government in India. There Sir Bampfylde Fuller tells us that 'from irrigation works maintained by the State seventeen million acres are irrigated-an area half the size of England'. 'Not only do these canals increase prosperity; they create it. Two of the Punjâb canals literally have converted desolate uninhabited plains into thriving countries. Along the Chenâb canal now stretch fields and villages inhabited by a million people, where twelve years ago a few nomads wandered over a desert of parched earth and camel thorn. The State irrigation works of India are, of their kind, the greatest and most beneficent triumphs of engineering that the world has seen.' 2

There were no doubt cases in which, by draining, reclamation, and irrigation, the Romans did creative work, making land existent, which for men to dwell in and for productive purposes had been nonexistent before they came. To Roman handiwork, for instance, aided by the receding sea, we owe the

1 The Provinces of the Roman Empire, vol. ii, p. 253.

${ }^{2}$ Studies of Indian Life and Sentiment, by Sir Bampfylde Fuller, K.C.S.I., C.I.E., 1910, pp. 322 and 195. 
rich cornland of Romney Marsh. "Parts of' Algeria, now wholly barren, were fertile and populous, owing to their unsurpassed system of imigation, and 'modern travellers notice with antmishment the ruins of what must have been flouri-hing aties fint beyond the present limits of Algerian civilizattion ? In the Haturam, eant of the Jurdan, they built, irrigated, and reclaimed. "At this eastern linnit of the Empire there wats gained for Iellenic civilizattion al fronticl domain which maty be compared with the Rominnized region of the Rhine.'" But in the Himran, as in Eastern Egypt, they were not the first pioneers, and their benefieent work reems to have been done on or near caravan or trade-routes.

Perhaps it may be summed up that the Romans set themselves to make the best use of water which was on the spot, and to bring to the spot watter which was within comparatively ealsy reach. But, even where it wats a question of existing watere, in the albsence of modern appliances, no linge river was eontrolled by them, to anything like the samse extent that the Nile hats been by the great works of latter day's ; and where it wats a question of hringing water to where water wats not, the supply was brought to a limited area and from a short distance away. The Romans had the Libyin desert on their frontier, but they had no call to try and reelim more than its fringes. They were not filced with,

'Arnold's Roman Irorincial Administration, l'l. 41. 22:3.

2 Mommsen, The Prorines of the liomun Eimpire, vol. ii, 1. 158.

1473 
and did not attempt to handle on a large scale, the problem how to make a desert not a desert, which is the problem that faces us in the interior of Australia, and which, if ever solved, will make the rise of the South more important than ever in the history of the world. Here we have a Province, which is in itself a continent, greater in size than the Roman Empire, and the future of this continent is mainly a question of water supply. Water means population, and production, and, therefore, science will in a unique degree determine the position of Australia among the nations of the world. An instance has been given, in Western Australia, of bringing water from a long distance, measured by the surface of the earth. Elsewhere, especially in Queensland, we have water brought from a comparatively long distance within the earth, by artesian wells, which would not have been possible without the aid of modern machinery. The great central artesian basin in Australia is estimated to extend over more than half a million of square miles and to underlie more than half the State of Queensland. The boring has been carried down to a depth of 5,000 feet, not very far short of a mile. Thus underground water is being made available to an extent wholly unknown to the ancients. How far the supply will be permanent, or how far a not unlimited stock is being depleted, has yet to be fully proved; but the measurements which have so far been made of the flows of the artesian bores point distinctly to 
a decrease in the supply. This is a calse of mining for water, which would be useless, if the water were not there alreanly. It is for the future to determine whether by humin ingenuity a purely waterless region cam be mimle water-bearing; and also whether the art of turning salt water inte fresh by the process of condensing, which again wats apparently unknown to the Romans, ean he inplied upon any lillge sciale.

Watter is one great agency in making unhabitable places habitable, and habitible plikes more habitable. Another is medical science. When the history of the British Empire for the past thirty years comes to be written; if it is written aright, one of the leading features in the story will be the rire of medieal science into the front rank of humin agencies which are malking and kecping timpires. The lifetime of a midhle-iged main at the present day covers the main part of the discoveries connected with the germ theory of disease, the work of Pasteur, Lister, Koch, Latveran, and others, carried forward more especially in the British Empire by Manson, Russ, Bruce, Boyce, and their fellow workers. Lard Lister, who hats but hately died, in the latter part of his life, when he had revolutionized surgery, gatse his great name and influener to the mosement for combating tropical diseanes: and seience received suppert from statesmanship the strong support of Mr. Chamberlain, as Secretary of State for the Colunies. The movement is still in I 2 
its infancy, but the discovery that flies and mosquitoes are the conductors of disease, that the anopheline mosquito-as indicated by Sir Patrick Manson and proved by Sir Ronald Ross-is the bearer of malaria, that the stegomyia is the medium of yellow fever, that the tsetse fly infects horses and cattle, that one or more species of that fly are the agents for spreading sleeping sickness among human beings; all these and kindred discoveries hold out promise that the future record of the tropical dependencies of European nations will be widely different from the past.

We find no analogy to what is now taking place in the history of the Roman Empire. The Romans had plenty of common sense and rare power of organization. They were well alive to the calls of public health, to the virtues of fresh air, of pure drinking water, and of good sewers. They knew that marshes cause fever: they even connected disease with insects bred in marshes, and mosquito nets are mentioned by Roman classical writers. ${ }^{1}$ They or those whom they ruled, the Greeks and others, had considerable knowledge of medicine and surgery. There were writers on medical subjects, consulting physicians with large practices, and medical officers of health. ${ }^{2}$ But there seems to

${ }^{1}$ See The Prevention of Malaria, by Sir Ronald Ross, 1910, chap. i, pp. 5-6.

2 'The regular organization of public medical attendance in the Provinces dates from Antoninus Pius, who required the towns of Asia to have a certain number of physicians among their salaried officers.' Dill's Roman Society from Nero to Marcus Aurelius, 2nd ed., 1905, p. 219. 
be no recorel of their making any great diseovery of the cause and the prevention of some witespreand disease in man or animal, whioh womhl have effect on whole Provinces or groups of l'rovinces. They

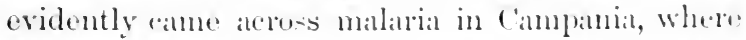
Pompey eaught fever, but what tibhom terns the fertile and happy Province of Cimpintil, the seeme of the early viotories ame of the eleliedum retire. ments of the eitizens of Rome ', must have beenpossibly hecallse it was better drander-widely

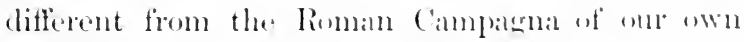
day, the home of malaria and, he it noted, the scene where in 1900 it was poved to demonstration that remaining at night time in a mospuitorepond dwelling confers immunity firom malarial fevert.

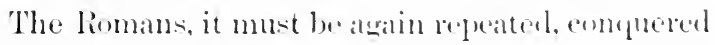
and held in subjection hane areals, but for pratetieal puposes handled only towns and small aneas. They were very rarely pioneers. They diel not settle fin. affehl, or stray into jungle or hush. Sor diel they administer tropical dependenedes, lamels where Emopean new-eomers were in tanger of their lives from elimatie calleses. In other works, mediral seience among the Rominns wis mot ralled upun to

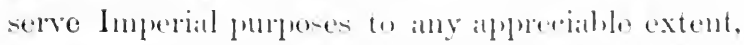
or, perhatpe, it would be more anderet tes sily that the Imperial purposos which medieine served anomer

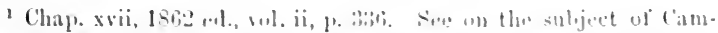

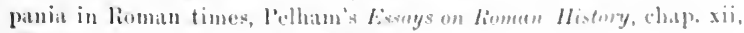
- Discoveries at Rome', Ple. :2ti-it. 
the Romans were smaller and narrower than ours. The most that medicine did for the Roman Empire was to keep the soldiers as far as possible in good health, and to keep the towns and small highly planted and civilized areas in good sanitary order.

If we take our own Empire, we find that medical science is working its beneficial results on a large scale in all the tropical and subtropical dependencies, as well as in Egypt. Malta fever, for instance, which has a far wider area than Malta or even the Mediterranean, since Sir David Bruce's Commission traced its origin to parasites, conveyed in goats' milk, has, where the use of that milk has been discontinued, almost entirely disappeared. India and the Far East, the West Indies, the North of Australia-all the tropics are becoming healthier for white men and coloured alike; but perhaps the healing art, now become the preventive science, is doing its greatest work in tropical Africa, the land of the tsetse fly, of blackwater fever, of malaria, of sleeping sickness, of yellow fever, and many other diseases. What is medical science doing for this continent? It is making the parts which were unhabitable for Europeans, or barely habitable, comparatively safe for them to live in. It cannot make a tropical climate not tropical, but it can transform, and is already largely transforming, unhealthy into healthy tropics. English families have lived continuously in Barbados and Jamaica for between two and three centuries, proving that the British race can 
live and thrive in healthy tropies. It does not seem eredible at present that the West Coast of Afriea will ever be thus colonized, but it is alrealy a lifferent place firom what it was forty years ano. largely becalse medical seience is conquering malirial. Assuming that it can never be a lome for British settlement, at least the economic results of medical science will be most marked. Arlministering, tratling, developing, will be carried wn without errevous loss of health and life, and without the consequent expense. The deally lambli will become seenes of everydaly coming and enoing, not to be visited and left, but to be risited and returned to in safety and comfort.

The doctor in the past wats ealled in to rure and to alleviate, by the individual rather than the state. He is now looked to, like the engineer and the water-bringer, to remose the obstacles which nuke against living in eertain parts of the world. When Lord Lister died, The Times wote, 'It is the drawbatek of so many discoveries and inventions that they take away from us almost as much as they give,' ${ }^{1}$ and pointed ont that no sulh drawhitek attarehed to the lifework of the great streneon. What merlical seronce is doing for the British Empire is wholly a gatin. Outsicle the spiritual sphere it is the most pumly beneficial aneney that ever worked for the highest lmperial atims. 


\section{CHAPTER VI}

THE INDIVIDUAL, THE COMPANY, AND THE STATE

Ir has been seen that the word Empire, and most of the words indicating parts of the British Empire, are of Roman origin. How far is that Empire itself in any sense of Roman origin? In other words, how far have the sources and methods of the British Empire been the sources and the methods which the Romans found and applied? The answer to the question is to be found by inquiring what part the individual and the State played in the two Empires respectively.

All great peoples and all Empires have had their great men, without whose agency they would not have been great; and personal influence and personal power were more to the front in old days than in our own; but the ordinary individual Roman played a smaller part in the making of the Roman Empire than the ordinary individual Englishman or Scotchman in the making of the British Empire. The British Empire is in the main an Anglo-Saxon creation, although its political nomenclature is Latin. In Mr. Heitland's Roman Republic, it is stated that the early Roman family 'was the groundwork of Roman life, for it is out of families, 
not of individuals, that the larger mits, clan, tribe, State, were formed': that the family was under the absolute rule of the fither: and that the power of the father in the fimily wits the morlel for the Imperium.' Noreover, it has heen seen that the dominant feature of the Roman Empire was that it was a military Empire. That is amother way of saying that it was a creation of the state. The State may have been emborlied, and morr often than not was cmbodied, in a partirular indivilual or in one or more particular leaders at a partienlan time, in Sulla or Julius Caresar or Aunustus or Trajan: but it was the state with its political or military leaders, rather than the private individual, that was the moving force.

We are told that in the Roman Empire, at any rate in its early and prosperous times, to a degrees now impossible commerce had the world in fee ; : but it could not be mantained that the Roman Empire was created by commere; on the contrary, commerce was ereated by the Roman Empire, by the fax Romana, the peace which was established by the strong hand of the lomans and their. legionaries. The same writer tells us that "trate from all parts of the Empire followerl the earles ; merchants and soldiers were fellow pioneers. similarly Mr. Heitland wites: Even hefore the

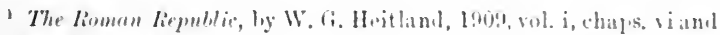
vii, l'. 35 and 39.

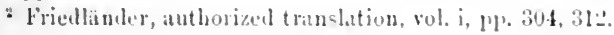


country was organized as a Province, traders (mercatores) were generally on the ground. Alleged ill-treatment of merchants was not seldom a pretext for campaigns and annexation.' ${ }^{1}$ Mr. Arnold again says that 'The Roman trader was ubiquitous. $\mathrm{He}$ even preceded the Roman arms.' 2 Romans traded with nations and races outside their Empire. If Mithridates found 80,000 Italians to put to death in one day in the cities of Asia Minor, it must be assumed that not a few Roman or Italian traders had made their way beyond the actual limits of the Roman Province. In the days of Augustus a large fleet of Roman merchant vessels plied between the Red Sea and the Persian Gulf and India, diverting as far as possible the trade of the Far East from the land route through Persia to the ports of Egypt. But none the less it seems safe to say that, in the making of the Roman Empire, the Eagles usually went first; that the merchants, for the most part, came where-to use the terms of our own Empire-there was already a Roman Pretectorate or Roman sphere of influence; and that, so far as they contributed to the creation of the Empire, they did so by giving ground for further intervention in lands where the State through its soldiers had intervened already. "The Romans were not an adventurous people' ${ }^{3}$ : they

1 The Roman Republic, vol. ii, p. 217.

2 Roman Provincial Administration, p. 18.

${ }^{3}$ Rome, in the Home University Library series, p. 11, by W. Warde Fowler. 
did not explore: they ronquered : and their trathrs. as a rule, waited till their soldiers had more or less dominated the lands. In other works, they waitenl for the State.

The Roman Empire began with eompuest ambl from first to last was manly the result of expansion by conquest. There was a centre, which enentre was a eity, not a comntry, and which, being a city, gatve its colouring to the whole, making the Provinese from the foman point of view rather eremper of town commmnities than areak of country. From this centre, as alreatly silit, the Empire wilened ont on all sides, always in continuty. hy movine frontiers outwards; and almost always ly eonupuet. that is to say. hy action of the stalte. The motive fores of the Roman Empire were the instinct of a military and conquering race. State polieg amb material advantages, tribute for the forernment and the governing rity, which meant relieving the citizens of the goreming eity from the necessity of paying taxes, and gain for the lioman merehants and ustures's who went out or sent out their representatives into the Provines.

The British Empire is not, and nerer was, the London Empire. It never wats the Empire of at rity, the Empire of a seat of Gorermment. Iondon is the greatest city of the Empire; but in wersian

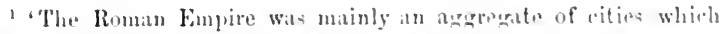
wore originally independent states.' lBury's History of the Inter fioman Eimpire, vol. i, 1. 37. 
enterprise, in early days, Bristol played a part as important as, or more important than, that played by London. What were the motives which led to the creation of the British Empire? Instinct, policy, material advantage, contributed to making it, as they contributed to making the Roman and every other Empire, but in very different forms and with widely different accompaniments. Conquest had nothing to do with the beginnings of the British Empire. The State at first played a very small part. The individual played a great part and led on the State. The Empire began with no continuity whatever, either of acquisition or of system. There was exploration, adventure, trade, and partial settlement which the Government licensed, disowned, or ignored at will, and which was all due to private initiative. There was little or nothing in the Roman Empire answering to the work of British explorers, adventurers, traders, and privateers in the sixteenth century, before England acquired any possession whatever overseas, with the exception of barren sovereignty over Newfoundland, or to the work of traders and colonizers of the seventeenth century.

The story of our Empire has been that British traders have always gone in front of the soldier and the State. They did not in old days content themselves with trading in Provinces which had been already made British or in which the strength of Britain had at least been felt and recognized. They 
traded and mate footholds in foreign lands which became British in eonsequence of their trading. 'That has been preeminently the story of the English in Indi:.

Religrion hats hatd much to saly to the creation of the British Empire, and in at much greatter elegrees ats a personal influence than ats part of at State polieg. The missionary in our overseats reeorels must be placed side by side with the trader ats a pioneer of Empire. If it had not been for Lavid Livingstone, for instance, it cam hadly be suppersed that we should now have the position which we have seeured in C'entral Africa. Religious comvetion anain, or religious aversion, sent out British men and British fimilies in numbers to settle overseats. For the Romans, on the other hand, and in the making of the homan Empire, religion had little inspiring personal foree. There wats a State religion, but there was much more State than religion in it. 'It was the religion of the family, the religion also of the Empire of the worlel. Beginning in rustic simplicity, the traces of which it ever afterwarels retained, it grew with the power of the Roman State, and beeame one with its laws. No fancy or poetry moulded the forms of the Roman gods; they are wanting in character and hardly distinguishable from one another. Not what they were, but their worship, is the point of interest about them. 'Those inamimate beings oceasionally' satid a patriotic word at some eritical juncture of the Roman affiurs, but they hat no attributes or qualities; 
they are the mere impersonation of the needs of the State.' The Roman religion 'was truly the "established" religion. It represented the greatness and power of Rome." The Romans adopted other people's gods in addition to their own. Religious toleration was conspicuous among them, except when they saw political danger in a creed such as Judaism or Christianity; but their toleration was the toleration of indifference, and religion cannot be said to have been a living personal force to the Romans. Rome was not inspired to conquer by religion. Her conquests were not made in the name of and to the glory of the Roman gods. Nor did Roman pilgrim fathers go out to settle in strange lands. Christianity was the very opposite of the Roman religion. It made itself felt in the Roman Empire, as the religion of the individual not of the State, and thus, as Professor Bury points out, it operated as a dissolvent force in the Empire. It ' emphasized the privileges, hopes, and fears of the individual. Christ died for each man. It was thus opposed to the universality of the Roman world, in which the individual and his personal interests were of little account.' ${ }^{2}$

Over-population and consequent distress seems to have contributed to Roman as to British colonization, but the difference of the two cases is

1 Select passages from the Theological Writings of Benjamin Jowett (1903), p. 163.

${ }^{2}$ Bury's History of the Later Roman Empire, vol. i, pp. 33-4. 
very matked. 'The oversea colonies of Cains Gracehus were designed to relieve the orer-population of home or Italy and find lind for poor citizens. The colonies planted by Augustus had a similar intent, though, like most Roman eolonies, they were lamely eomposed of old soleliers. 'The Western half of the Empire could not have been so thoroughly Romanized, without a considerable amount of voluntary settlement of Romans and Italians in the Provinees, side by side with existing, or forming the nucleds of future colonies. But none the less the main feature of the Roman colonies was that they were part of a political machinery, whereby groups of homan eitizens were plinted in conquered lands, holding in elseck existing communities which had come under the rule of Rome. In short, Roman eolonization wits in its essence a state matter.

British colonization, on the contrary, has in the main been independent of the State. Concuest and colonization have orerlipped each other at certain periods in our overseas history, and in ecrtinin places, as in Canada; but, for the most part, the field of conquest has been distinct from the field of colonization. Cibbon Wakefield propounded at seheme of colonization, whereby the distribution of lands and the course of emigration were to be regulated by the State, and Lord Durham gave his high aluthority to the support of Wakefield's views; but those views never really took root, and British emigration ats at whole went its waty on the lines of the individual, 
not of the State. Now and again in the history of our Empire we find something that reminds us of Roman times and Roman ways, as when after the Crimean war the German legion was planted out in British Kaffraria and the eastern districts of the Cape Colony; but if Roman and British colonization are set side by side, they differ on the whole, as town differs from country, as conquest differs from peaceful settlement, as the State differs from the individual man.

But, while the State was always in evidence in the Roman Empire, and while the individual rather than the State was the motive power in the British Empire, not only have there been eras in the British Empire when war was predominant and, therefore, the State, but also in many cases where and when the individual has been doing the work, some kind of sanction and of indirect support has come from the State. The eighteenth century down to the Battle of Waterloo was what may be called the State era in the British Empire, the era par excellence of gain and loss by war and of the direct action of the State. Canada, framed to be and proved to be a field of colonization, not a dependent Province, was secured not by British settlement but by war and by the State. Australia, a field of colonization, the one great possession peacefully acquired in an era of war, was none the less acquired by the direct action of the State. Moreover, when and where, in the making of the British Empire, the State has neither 
taken the initiative nor directly intervened. Wo an often trace indireet intervention, notably in the grant of Royal Chaters to assoeditions of private eitizens.

The part played by the state and the indivilual in the Roman and the British Empires respertively can be well illustrated by eonsilering and contrasting the position and the work of emmpanies in the two Empires. Trading partnerships and companies alle not peculiar to any race or any time, and among the Romans, as among other peoples, private citizens or associations of private eitizens took contratets from the Government for the construction of public works or for other services, fust as companies of contralctors tender for and mulertake the erection of public buildings, the building of ships, the supply of stores, the conveyance of mails and various public services at the present moment. It is stateel thit joint stock companies or syndicates first came into evidence in Roman history ats doing work for the Statr, at the time of the Second P'unic War, towards the end of the third century lice, when they tendered for supplies to the Roman army in Spain; but the companies of whom we hear most in commexion with the Roman State were the Siccetutes Pullicanorum, the companise of midtlomen who farmerl the tithes and other taxes in the later days of the Republie, and farmol some of the taxes meler the Empire. Under the Ropublir they patid a lump im

1 Heitland's Lomen liepublic, vol. i, pl. 270, 351. 
in each case to the Government and made what they could out of the taxpayers in the Provinces, being notorious as machinery for extortion and misgovernment. The members of these companies were capitalists, belonging exclusively or almost exclusively to one particular class of Roman citizens. Thus it may be said that in the Roman system, companies, so far as they had to do with the State and the Empire, were purely private companies, but were most in evidence as undertaking by contract one of the principal functions of the State, the collection of revenue. They were private citizens who were middlemen and monopolists of State revenues, who did not produce or create directly or indirectly for the State, but who took over purely State work as a matter of speculation. Their existence and their functions seem to point to the fact that the Romans, if State led, were, at the same time, by no means State ridden. In modern days State intervention is accompanied by multiplication of officials, whereas in lieu of creating a regular Civil Service to collect their revenues, the Romans, at any rate in the earlier days of Roman rule, left the duty to private contractors.

There does not seem to be any parallel in the British Empire to these companies of publicani. On the other hand, there is no parallel in the Roman Empire to the chartered companies, who have played such a notable part in our own Empire. In a sense these companies have been middlemen and monopolists, that is to say, they have been a kind of inter- 
mediate ageney, really doing State work, and in their original guise in past centuries they held at trading monopoly from the State ats against other British citizens. The great East India Company held a licence or chater from the Crown to rary on trate in certitin lands and waters to the exelusion of other British traders. But the shatrelublers in the Eist India Company and in other British ehare tered companies were not concerned with expleiting lands which had ahrealy been thoromghly conquered and dominated by Great Britatin, nor with sperenkating in revenues which acerned to the British (iovernment, but with tracling in lands wholly ontside British rule or colonizing linds which were at most only british in name. They held no contratets from the Government, only a licenes from the Govern. ment and a satfeguand against competition from home. They took the whole risk. They mate no profit out of the State, but indireetly brought profit to the State. A societus I'ublicanomem was a purely private company, not incorporated by the sitate, but it did absolutely nothing but speeulite in statte work in countries which beloned to the state. The kist India Company was not a purely private rompany. in that it was incorporaterl by the statte, but it embodied private British ammereial enterprises. It illustrated the intiative of private British eitizens, who went in front of the state and played a conspicuous part in hulding up the British Empire. Roman eitizens never seem to have formed atsonedat(, : 
tions of this kind and on these lines. They did work for the State and made profit out of the State, but they took their lead from, rather than gave the lead to, the State; and they did not to any appreciable degree go outside and beyond the State.

The merits and demerits of chartered companies have often been discussed. Whatever may be said for or against them, the fact remains that the British Empire, as it stands to-day, is in no small degree the outcome of chartered companies, which have been a machinery peculiarly adapted to the British type. There are three points in this connexion which it may be well to emphasize, that chartered companies have been of different degrees and kinds, that there have been two distinct eras of chartered companies in the British Empire, and that these companies have been of rather special value to that Empire as contributing a much needed element of continuity.

The Spaniards and Portuguese did not make much use of chartered companies for their overseas work ; though comparatively late in their history, in the middle of the seventeenth century, the Portuguese, under pressure of war with the Dutch in Brazil, took a leaf out of their enemy's book and established a Brazil company; while a century later, the Portuguese minister, Pombal, created similar companies, also in connexion with Brazil. The French used chartered companies, but the genius of France did not lie in this direction. French chartered companies 


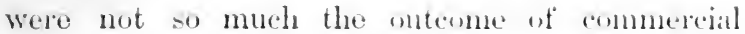
initiative from helow ats the reations of the sitate from above; and in loance the state was the King and his pantionlat Minister for the time heinge.

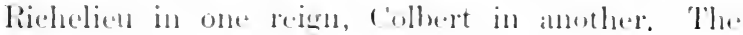
Ferele companies, therefore, wanted vitality, ther suffered from constiant interference ly the Giovernment and were gerpetmally mate and numalde. 'The Northern-the 'Teutun and sicanlinavian-peoples, especially the lonteh and the Euglish, were mont

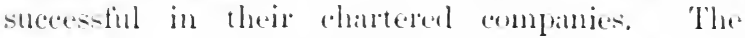

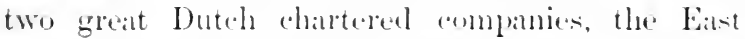
India Company and the Wext India C'mpany. pratetieally embndied the state in its werseals dealiness. 'They were national associations rather' thath grivate conecons. The bitish chartered companies, on the nther hand, were private concents rather tham national associations; but they did mational work. The influence of the State in ene nexion with chatetered enmpanies was fin more fielt in France and in the Setherlands than in England. In France it worked anainst strength and contiunity, and killed the usefulness of the compranies. In the Netherlands it save sueh wholesale and eontinuous suppert to the complatios that they were pratetically identified with the state. In linerland the fiovern-

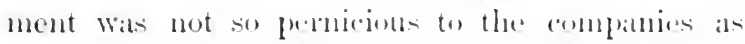

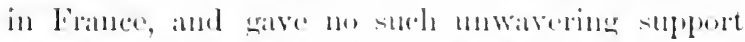
to them ats in Ilolland. 'The ligitish rhitetered compantes remanined private complanies. 
As the historic British chartered companies differed from the chartered companies of other nations in being less closely connected with the State or less constantly interfered with by the State, so the later British chartered companies have differed from the old chartered companies. The old chartered companies, which contributed so greatly to the making of the British Empire, may be said to have come to an end, at any rate in their Empire-making capacity, when the Government of India was taken over by the Crown from the East India Company in 1858, and when the Hudson Bay Company in 1869 surrendered their territorial rights to the Canadian Government. But within a very few years from this date a new series of chartered companies came into existence, for between 1880 and 1890 the British North Borneo Company, the Royal Niger Company, the Imperial British East Africa Company, and the British South Africa Company, all received charters from the Crown ; and through their agency, directly or indirectly, little short of a new Empire came into existence. It is one of the most interesting features in the record of the British Empire, that its latest developments have been accompanied by and largely accomplished through the agencies which did so much for the original beginnings of the Empire. Once more in British history the individual led the State, and the State worked through and gave some endorsement to the individual. The first of these latter-day chartered companies, still in vigorous 
operation, was the British North Bornco Company, which received its charter in 1051. 'Th. fommlers of the company hald alreally aeruired a latege extent of territory from native sultins, but in syanting the charter, the Crown assumed no Dominion an sovereignty over the territories so alequired - stede ats would have been assumed under the old rhaters, and instead of giving to the comprony in the ir sphere of action a general monopoly of trate, it expresily prohibited any such general monopuly. Thu the new type of charter differed from the ald tye in that the State disclinned sovereign rights asel. territorial aequixitions mate by its subjects, therely holding itself even more aloof than before from tho responsibilities which the private citizens incurred; and, on the other hame, it restrieted the tratling monopoly which hate been the matinspring of the old companies sis as to ensme that indivilual atizens, other than shareholelers of the eompany, should tratede at will with the territories which the complany hat acquired. In either respect the new type of chatrer tended to enconmere private initiative. ${ }^{2}$

The weakent point in British colminil poliey, taken as a whole, has been want of continuity. Must of our mistakes and misfortunes, motally in the palnt

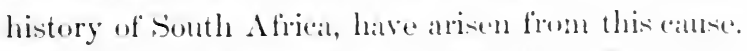
Writing of the state of feeling in Uprer Cimblat at

Tor a comparison of the old and the new chateres refierence should

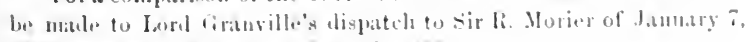
1-5.', printed in Blue Book C. 310\%, 1 mo?. 
the time of his mission, Lord Durham said in his report, ' They ask for greater firmness of purpose in their rulers, and a more defined and consistent policy on the part of the Government; something, in short, that will make all parties feel that an order of things has been established, to which it is necessary that they should conform themselves, and which is not to be subject to any unlooked for and sudden interruption, consequent upon some unforeseen move in the game of politics in England.' 1 In this respect the Romans were infinitely superior to the English. They had a defined and consistent policy, and established an order of things to which all peoples in their Empire felt that they must conform themselves. This is the good side of State omnipotence, as opposed to individual freedom and initiative. Individual freedom has made itself felt in bringing about party government in England; and, so far as party government has affected Imperial policy, its influence has been all for the bad because it has been all against continuity. It has been stated above that in the beginnings of the British Empire there was no continuity and no system. This was in the seventeenth century, when the great Civil War took place and when State authority was constantly changing and much at a discount. But this same age was also a notable age for chartered companies, and chartered companies in their work beyond the seas in no small degree supplied the continuity 
which the State did not give, for they held under the Government for the time being, whether it was thi king or that king, or king or Parliment, and so far ats their individual nembers diel not eompromise them. they had nothing to do with one party rathere than another. Being chartered companies they han publi, recognition at home and abroand, being composed of private merehants they did not stamel or fill with this or that ciovermment or party. In the seventeenth century very especially, but also in kater ages and in our own times, these companies have conspicuously contributed to continuity. For this we owe them a debt of gratitude, ats also for the seope which they have griven for evolving a ratere of administrators out of trading surroundings which leel on to conquest and to rule.

If the private British citizen, either alone or in combination, has taken a great part in making the Emprire, he lats a great part to play in kecping it. Empires neessiarily imply inchusion of different races and different types of the same race. In all Empires individuals must have great indirect influence. The individual Briton or German or I)actan or Numidian must have formed a liking or a hatred for the Romans ats a whole, latrely from the kind of individual Roman with whom he came inte contalet, just as the native of India nust inevitably jullere of the British people ats a whole from the indivielual Englishnen whom he has served or whom he has met. But the less an Empire depends upon foree of 
arms, the more it depends for cohesion upon individual characteristics, and in this respect, as in others, the individual is of more importance in the British than in the Roman Empire. He is perhaps of most importance in that half of the Empire from which the element of force has been most eliminated, that is, in regard to the relations between the SelfGoverning Dominions and the Mother Country. State wisdom or unwisdom may do much to make or mar good relations, but a more potent force still, and growing in potency as the opportunities of meeting multiply owing to better communication, is the action and reaction of individual citizens. This point has already been referred to in a previous chapter in connexion with the subject of old and young peoples. It is impossible to exaggerate the good which can be done by individuals and associations of individuals, such as the Victoria League, which bear in mind the individual from over the seas. For an Empire is a collection of human beings who live individual and private lives, and it will never be made one or remain one, unless public ties are supplemented by private intimacy and friendship, and unless to the sense of common citizenship is added the sure feeling of welcome to the family and the home. 


\section{CHAPTER V'H \\ ('LAS, (OLULR, ANI) RA'E}

The main diflerences between anceient and molern political systems are usually helel to be, that in the ancient world representative institutions were moknown, and that slavery wais a fumblamental element in every ancient community. Negros strery and the slave trade have stained the recorels of the British Empire: but only in certain tropical dependencies of Great Britain-mainly the West Indies-Wass sarery ever in any sense an integral fieter. In the Roman Empire, on the other hamel. it wats a stancling and universal institution; and the existence of slivery throughout that Empine ereated a great clatss distinction between freemen and slaves, which wats both political and social, and which neither hats non ever hat any comnterpart in the British Empire. Under the eonditions of the old worlel, slavery wats not inimieal to Empire: and in the Roman Empire it was not altogether a souree of weakness and dinger. Mr. Armold states that, with the extension of the eitizenship, "the Roman Empire eame to be a homogeneous matss of privileged persons ; ${ }^{1}$ and it maty farly be aremed that the existenee of starery

\footnotetext{
'Loman Irorincial dalministration, 1. 42.
} 
tended to produce this result, and to create a bond among all those within the Empire who were not slaves, as being privileged persons, which bond counteracted differences of race. The Roman Empire was a military despotism evolved out of a Republic or an oligarchy which had ceased to meet the requirements of the time. Slavery harmonized with despotism; it was in a sense an appropriate base of the pyramid; slaves and freemen alike were of various races and colours; and the result of slavery in the Roman Empire was to make a class distinction which not only did not follow but tended to obliterate the lines of race.

Among the freemen of the Roman Empire how far did class operate? What relation did it bear to race? and how far can we find parallels in our own Empire?

It is very difficult to compare Roman and British citizenship, or, as has been shown by a recent discussion in the pages of United Empire, to define exactly what British citizenship means. Citizenship among the Greeks and Romans attached to the persons, not to the place where they lived. The State was a collection of citizens, not a territory; for the earliest basis of political community, as Sir Henry Maine has pointed out, was kinship in blood, not local contiguity. ${ }^{1}$ Full Roman citizenship included both public and private rights, the former consisting of the franchise and eligibility to office in

1 Ancient Law, chap. v. 
the State, the latter embolying, among whel privileges, exemption from what amounted to martial latw. "The matrtial law moler whirh all other provincials lay, diul not apply to him who eould saly with St. Paul, "I am a Romam.", In the early days of Rome there was a great gulf fixed between the eitizen and the non-eitizen, hetween the rivis and the peregrimes, and thomgh citizenship diel not attach to the soil, it is interesting to motive that land within the bommlanies of the old limman State Wats held hy a specially privileged temure in limman law, which wats afterwatrds extended to most of the soil of Italy, but not to the Provinces. As Roman power widened in Italy, different shades of partial citizenship came into existence: privite rights, all or some, were griven to individuals; publie rights, all w some, were given to town communities. Then the full Roman citizenship was extended to Italy ; and finally, at the beginning of the thirel century 1.1 ., it was made universal throughout the Empire. From this time the only distinction left wats that hetween freemen and slaves. It will be noted that the more Roman citizenship extended beyond the city walls, the less valuable one element in it, the framehise, became; for, as the Romans hald no representative institutions, a Roman eitizen could only vote by going to Rome, and when the Republic Wits exchanged for a despotion the vote at hime heeame of little value.

1 Arnold's Roman P'rovincial Atministration, pp. il-2. 
Starting originally with the tie of race as the basis of citizenship, the Romans stand out beyond almost all peoples in the extent to which they disregarded race, and in the liberality with which they widened their citizenship. Here is Bacon's verdict upon them :

' Never any State was in this point so open to receive strangers into their body as were the Romans. Therefore, it sorted with them accordingly; for they grew to the greatest monarchy. Their manner was to grant naturalization (which they called jus civitatis), and to grant it in the highest degree; that is not only jus commercii, jus connubii, jus hereditatis, but also jus suffragii and jus honorum. And this not to singular persons alone, but likewise to whole families; yea, to cities, and sometimes to nations. Add to this their custom of plantation of colonies, whereby the Roman plant was removed into the soil of other nations. And putting both constitutions together, you will say that it was not the Romans that spread upon the world, but it was the world that spread upon the Romans; and that was the sure way of greatness.' 1

Emphasis has been laid in the preceding pages upon the military basis of the Roman Empire; but that Empire was, it need hardly be said, infinitely more than a mere creation of brute force. Gibbon calls the story of Rome 'the rise of a city, which swelled into an Empire'.2 And in truth the Romans

1 'Of the true greatness of Kingdoms and Estates,' Spedding's edition, vol. vi, p. 448.

${ }^{2}$ General observations on the Fall of the Roman Empire in the West (Decline and Fall, 1862 ed., vol. iv, p. 403). 
were the one people in the history of the world who gradually and surely expanded a town into at wolde wide community. With singulat breatth of view and practical statesmanship, they widened the city state by extending the privileges of the walled eity of Rome to individuals and peopless whom the eity amd its eitizens had conquered. Their great invention in polities Wals universal ritizenship developed ont of the citizenship of one-the sreatest ammor many cities; ant we owe to them municipal government in the modern sense, in that they ereated a rombination of limited local self-encernment with the wider Imperial status which originally attitcherl unly to the central eity, home.

Now what does British citizenship ammunt to? The inhabitants of all territories whirh have beren formally ammexed by Great Britain are British subjects, and are entitled to all the privileges which British subjects ealn claim ats agatinst foreigners. They ale ciess as against peregrini; and their privileges attach to them in virtue of being natives of British soil. But the British Empire includes large territories which have not been ammexenl and are not British soil. They are British Protereterates, and the natives of these Protectorates are not in the eye of the law British subjects. These British l'rotectorates seem to be somewhat analogems to the civitates fordereter in the earlier rass of homan history, before all political distinctions were swept away. Naturalization again is not as yet on one and 
the same basis for the whole Empire; though it must be noted that when Bacon, in the passage which has been quoted, speaks of Roman naturalization, he means in effect the raising of Roman subjects into full Roman citizens, whereas British naturalization means the conversion of foreign subjects or aliens into British subjects. The result of the discussion on naturalization at the last Imperial Conference was to make a further advance towards uniformity in naturalization throughout the British Empire; but still, at the present time, a man may be naturalized in Canada under the Dominion Laws and become a British citizen in Canada, while, if he moves within a certain time to some other part of the British Empire, he ceases to be a British citizen. Nor is there any uniform franchise for the whole Empire, inasmuch as though there is an Imperial Government, there is not, as in the Roman Empire, one Government and one only. British subjects in India are cives sine suffragio; and while British subjects in Canada have the jus suffragii, it is not a vote for the whole Empire. Nor once more have all British subjects the full jus honorum. For instance, there is a remnant of religious disabilities in that a Roman Catholic cannot be Lord Chancellor of England. Race disqualification, though very rare under the Imperial Government, is illustrated by the fact that candidates for the Civil Service of the Far Eastern colonies must be natural born British subjects of pure European descent; and it may be 
presumed that some of the highest posts in the Empire would in faet be reserved fir white men.

The greatest difficulty in the British limpire is probably the colnem eflestion. It hate been alleamly

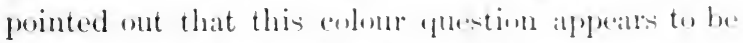
a molern problem. There is litte reforence to it in Roman writers. The hembus were not ralled

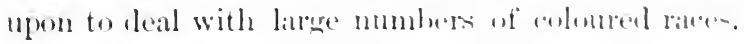
The alien peoples with whom they were hromedst

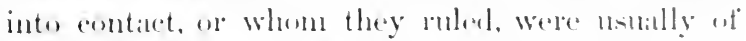
the sime colome as themedrest and when amel

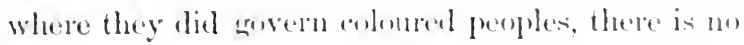

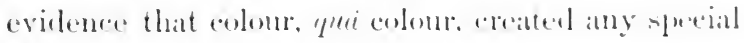
barrier between rulers and ruled.

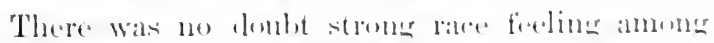
the Romans for the West ats athet the Filst. The Western half of the Empire Wis Romanisel. The Eastern halt wats Hellenized. The Lemmin monle! was followed, Roman colonien and munidine were multiplied, to a enceater extent in the Went than in the bist; and the liomans drew their leathers and

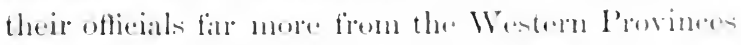

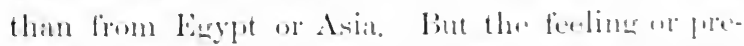
judice does not seem to hatre been primarily hased

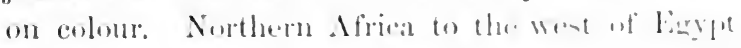

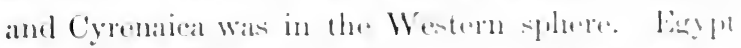
was in the bistern. Colem munt have beren at

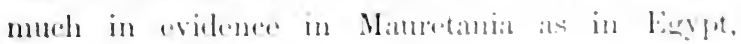
but there was at liae instinet ambne the liomams against legpt and it wass which diel not apply 
to the Romanized districts of North Africa further West.

Nor again, as has been said, was slavery in the Roman Empire in any way based on colour; and it is probably to this fact, as contrasted with the fact that in modern times a special coloured racethe Negro race-was marked out for slavery in the overseas possessions of European nations, that the difference of feeling on the subject of colour in Roman times and in our own should be attributed. Or possibly it should be traced more especially to the time of abolition of slavery and the consequent equalizing of the white and black races in the eyes of the law. Slave emancipation intensified with apprehension the colour feeling of the white oligarchy in the lands where slavery had prevailed, and it may well be that those lands became a nucleus whence colour prejudice spread outside the former areas of negro slavery, and coalesced, for instance, with the feeling of West as against East, in which, far more than was the case in the Roman Empire, the element of colour is also present. ${ }^{1}$ In the SelfGoverning Provinces of the British Empire at the present day the coloured natives of the soil, though British subjects, are, more often than not, excluded from the franchise, as in Australia, for instance, or parts of South Africa, or British Columbia; while

1 On the subject of the colour question in ancient and modern times see Lord Cromer's Ancient and Modern Imperialism. The views which he has expressed seem to be generally accepted. 
in New Zealand, the Maroris have at special represen. tation; and most, if not all, of the self-toverning Dominions have laws designed to rentrict the admission of eoloureal immigrants, whether they are British subjects or whether they are not. In other words, in the british Empire there are disabilities attalching to rater and colour, which found no place in the Roman Empire.

It should be moted, howerer, with regatrel to the colour question, so fir als it conerems the relations between England and her dependencies at the present day, that the forling on the subjeret is not merely the result of prejulice, but the result alse of practical experience. In other words, colour prejudice is one thing, and what may be called colome discrimination is another. 'The white man may be, and usually is, projudiced against the colouned matn, because he himself is white, while the other is coloured; and the prejuliee is probably mutual. But the white man, or at any ratte the Englishman, also finds more rational gromel for discrinnination, in that the qualities, charater, ambl mphinging of most coloned men are not those which are in demand for at ruliner ratee, and are not, exrept in rare individual rases, eliminated by edereation on the white man's lines. The same discrimination is made by coloned races themselves, or some of them. A peasant in India would, jpeaking anerally, low for justice to an Englishman in preference to one of his own race, and if a colomed race has to 
submit to alien rule, the white man's rule would probably be preferred to that of coloured men who are foreign to the soil. It is one thing for natives of India to be placed in authority in their own land and over their own countrymen; it is another for them to be placed in authority over Malays, Chinese, or any of the African and Pacific races, and vice versa. Hence the system of open competition, as applied to an Empire of multifarious races, like our own, presents obvious difficulties and needs to be safeguarded. Had the Romans extended their rule into tropical Africa or Farther Asia, we might have heard more of the colour question in their Empire; and, as it was, though they took little account of different shades of colour, they practically drew upon the West for the government of the East on much the same principle that we look to our own white race for the administration of the tropics.

It may be summed up that in the Roman Empire there was a perpetual opening out of citizenship. The tendency was all towards fusion and uniformity, and race imposed few or no barriers. In the British Empire we have started with British citizenship of one kind or another as coterminous with British soil, in whatever part of the world the soil may be; but the tendency has been to greater diversity rather than to greater uniformity; and the lessening of distance has accentuated, instead of obliterating, distinctions of race. But at the same 
time it must be borne in mind that the grant of universal citizenship in the Roman Empire was combined with the stereotyping of military despotism. It would be perhatps more alcerrate to saly that all Romatn eitizens becane lowered to the level of Romam subjects, thath that all Romam suljecets were ratised to the level of Riontun citizens. Equality came in the Roman Empre ats the result of the losis of freedom. Diversity has developed in the british Empire ats the result of the growth of freedenu. 'The ratce and colom problem hats increatsed in diffieulty in our Empire in proportion ats some of the Provinees of that Empire have become more and more self-governing, is the Emprire hats developent into two Empires, of which more will be sitd in " later chilpter.

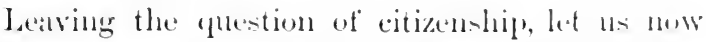
ask what class distinetions in the orelinally s.mete there were among the eitizens of the lioman Empire, and how fire they corresponded to omr own. 'llorese were rich and pour, then ats alwalys, very riell and very poor, millionatires and pallperts ats in whr wwn day, and ats the Empire Went on towalled deaty,

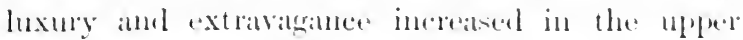

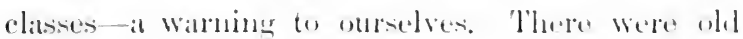

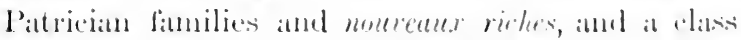

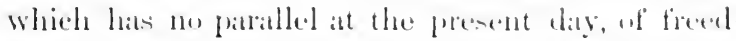

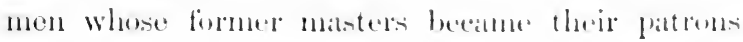

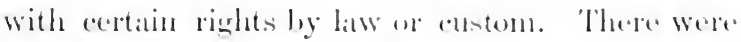
privilenges and disabilities attaching to partienlan. 
classes. Senators had various privileges, and from the time of Augustus there was a hereditary senatorial class, analogous to the peers in the United Kingdom, though the eldest son of a senator did not ipso facto have on his father's death a seat in the Senate. Senators, on the other hand, incurred disabilities. For instance, they were debarred by law and custom from taking a direct part in money-lending and financial business, and this business was almost exclusively in the hands of another class, the Equites. In the later stages of the Empire, social position seems to have been mainly determined by Government employment. 'The aristocracy of the Roman Empire in the fifth century was an aristocracy of officials. This is a fact to be borne in mind, that social rank ultimately depended upon a public career.' 1 In earlier days it may be assumed that, while bureaucracy was on the increase, social distinctions were, on the whole, much the same among Romans as among us; but we look in vain in the Roman Empire for a counterpart to the growing strength and importance of labour in modern society and in modern politics, and the development of a Labour Party or parties.

1 Bury's History of the Later Roman Empire, vol. i, pp. 38-9. The writer points out that the members of the senatorial class were wholly removed from local or municipal surroundings, that 'the senatorial world was thus the undiluted atmosphere of pure Roman Imperialism ', and that the Empire came to consist of the Emperor, the senators, and the mass of Roman citizens. 
Mammal libour anong the Romans Wis, umber the Republic and at the hegrinning of the Empire, almost exchusively slawe labour. "The slave elatis of antiquity really corresponded to sur free labouring clats." "The lioman plek, who demanded

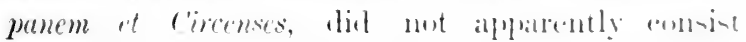
of wage-earlders. They were rather at privilengel clisss of unempleyed, who lexked to the statte and to the conquests mate by the statte to kerell them ferl and anused. 'This fiact, thit matnual labume wats in

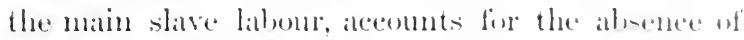
any definite labour movement or labour probleme in the Loman Empire, ats atpart from the gemeral question of poverty. We do not reald of questions as to rates of wateres and hours of work playing any alppreciable part in the story of limme and the Roman Empire, presumathy for the reatson that so many of the workmen were not eitizens lut chattels. In our own kmpire where white workers and colonred workers are siele ly side, ats in somth

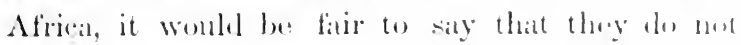
work on the sime level, and that the white mam is rither the oversece of, than the fellow-wotkman with, the colomed man, But notwithotameling. wherever both molomerl men and white ment are free agents, the element of taburt andertion enters in ; and where, ats in Anstraliat, the land in ly mature andipted to be a white man's lamblamb at the

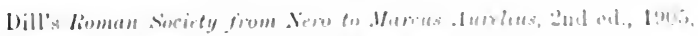
Bk. I, chap. iii, 'The socinty of the lreeduen,' 1, 102. 
same time the indigenous coloured men are not numerous, the tendency to exclude coloured labour is largely due to the white labourer's determination not to allow his labour to be undersold and his wages to be reduced by the incoming of cheaper coloured labour. Where slavery was in existence, no such element of competition could arise, for even if skilled slaves were wage-earners, they were not in a position to determine upon what terms they would sell their labour. ${ }^{1}$

$\mathrm{Mr}$. Dill tells us that under the Empire a numerous and important class of freedmen grew up and brought into the State the element, which had not previously existed, of free industrial labour. The different trades had their clubs and societies, somewhat resembling modern Trades Unions, but being rather combinations for social purposes than for the protection of wage-earners against the capitalists. ${ }^{2}$ If, however, free industrial labour on a considerable scale came into existence, it does not seem to have produced any of the political and economic developments which have attended the modern labour movement. Presumably, to the end, the proportion of slaves among the labourers was large, and among

1 For the extent to which at Athens (whatever may have been the case at Rome) slave artisans and free artisans were 'fellow-workers', see Mr. Zimmern's Greek Commonwealth (1911).

${ }^{2}$ In addition to what Mr. Dill tells us as to these Guilds or Clubs, see Mr. Warde Fowler's Rome in the Home University Library Series, pp. 223-5. The guilds seem to have been largely what would now be ealled funeral clubs. Mr. Fowler says that we do not hear much of slave labour in the provincial towns of the Roman Empire. 
the free labourers a considerable preportion were fiecdmen, men who had been slaves, who still wwed a kind of allegiance to their former manters. and who being themselves plated in a priviluged pention by the faret of having been given their fromblom, were not one in ferding with the whole multitul. of manual labourers. 'louse a mentern terme there watn no soliblarity in the labour moventent in the lioman Empire, if there evel wats any labme mowement at

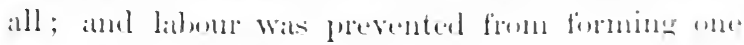
clatsis by being itself divided into the two endeat

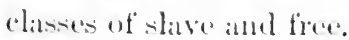

In onr own days the libbure mosement attrate miversal attention in the politiont and industrial workl. 'The Liberalism of the latet antury in this comntry, from the date of the great lieform bill onwards, directed its energies to curtaling elats privilenges and working for anmmon eitizenship and equality of ehances. 'The atim wats at noble one; the dream wats aradually to wipe ont elatsolistinetions in the statte, so that the statte shemhl all be one. But, as democracy enew in stronethe and more

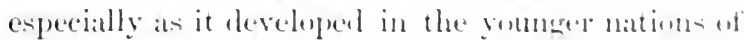
the British bmpire where enstom and tranlition hand

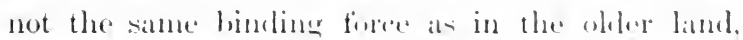
class reapleated from below and hecame far more

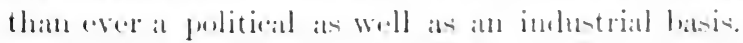
'Thus what haul been regatreled ats an evil hall

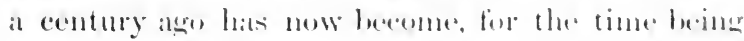
at any rate, a sottled principle of pulition: and 
a Labour Party, that is, a political combination based exclusively and avowedly on class feeling and class interests, is a prominent feature, perhaps the most prominent feature, in the public life of our time. How far does this great revival or new assertion of class accord with or militate against the instinct of race, and what bearing has it upon the future of the Empire?

The existence of a Labour Party implies the growing claims to ascendancy of manual labour; it is a pronouncement that manual labour has a right not only to safeguard its own interests, but to bid for and in the name of the majority to acquire the control of the State. The Australian Labour Party govern the Commonwealth of Australia at the present time. They govern it as being Australians, that is, as residents in or citizens of a certain country, and as being representatives of labour, that is, of a class. Other Governments in plenty have governed in fact as representatives of some privileged class; but in the case of a Labour Government and a Labour Party, class is openly inscribed on the banner. Now class is not coterminous with a particular race or confined by the limits of any particular country or Empire. We have seen that in the Roman system, the existence of slavery, that is, of class distinction in its most violent form, tended to modify and in large measure counteract distinction of race. What are the relations of class to race under modern conditions, class having become the 
fundamental basis of one great politieal party? The answer is that the lines of clasis latracly andede with the lines of ratee, so fir as the lines of rated coincide with the lines of colontr. 'The lathour mose. ment, ats it exists in the self (ioverning l)ominimnis beyoud question elosely allial to the finding of white andinst coloured raters. Ratere athingty prefors the white man to the colotured matn; clatss interent militates against the Indian of Chinese labentere ats willing and able to work for less money thatn the white workman. From this it follows that in the British Empire the tie of class roms anmede to the tie of atizenship. To the labour matn in

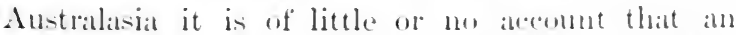
incoming colourel workman is a british sulject, it he comes from Indial. Ho is a roloumed 1nim, mot a white matn, and a mente datneroms compretitol in the wage market thath a white lalontrer, berambe hiconditions of life and terms of work atre not the white math's eonditions and terms. We hatse thent. as aganst the great fundimental clatsis distimetion in the Roman Emple hetween freemen and Matses, which wats not hatsed on ratee, at great fimdimental distinction in the British Enspire which is based on race, and which elass interest has indpeted and aceentuatiod.

But when we leave the enlone question ont of sight, and deal only with white men, how fitr d, class and ratce anderile? 'llee athawer is that the tie of elass runs eounter, if not to the tie of ratee, it 
least to the tie of nationality. It is one of the problems of the future, whether the labour man in a British land will be found in line with the labour man in a non-British land, as against the capitalist class similarly combined in the two countries, or whether the labour man and the capitalist alike will be British eitizens first and labour men and capitalists respectively only in the second place. So far as class feeling and class interest predominates, it is an influence working directly against the tie of nationality and citizenship of Empire. Problems of this kind did not greatly trouble the Roman Empire, for the simple reason that they are the fruits of freedom. The Roman Empire ultimately meant the Roman legions. As time went on, the different legions no doubt represented to a large extent different races, the West or the North or the East, but military despotism and the existence of slavery accounted between them for the absence of the conflicting tendencies which make the present history of our own Empire at once so perplexing and so full of interest.

It may be conjectured and hoped that the race instinct in the British Empire, more natural, less associated with material gains than the bond of class, will in the end prove the stronger force among the white citizens of the Empire. But there are cases in which this class tie has peculiar danger in the eyes of those who are concerned for the future of the Empire. The Trades Unions in Canada are in 
great measure affiliated to the Trades Lninns in the United states, and tho rhice centres of the Enions are in most eatses in the l niterl states. Here we have two neighbenting enuntres, nue part of the

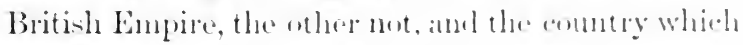
belongs to the British Empire in no small degree peopled from the Enited states. We hatre kinship in ralce, languatere, amel tranlitim, thomgh mot in nationality; and eonseptently leme, in at mulepe.

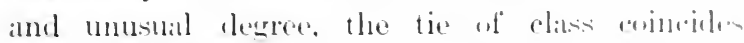
with the tie of ratce amble therefore, is a perulialy strong filetor ats anainst the tie of citizenship on nationality.

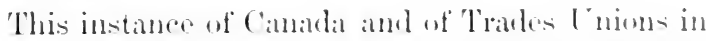
Canada with their connexions in the lnited statesuggests that, in a chapter dealing with chatsi, colour. and race, al point well worth attention hy those who are trying to forecist our future, is the plestion: What will be the politieal relations in the andning time between the British Empire and the Lnitul states? The question maty well be atsked, berameats a matter of fact one great Province of the Empirr. Canada, destined in the juelerement of matuy well able to judge to be the cormer stome of the arreh of the Empire, has had its whole history moulded hy the proximity of the Cuited stattes, and also hereamse the British future seems likely to Mhen it-edf in an increasingly eloser comnexion with the I Hirded states. There eomes, therefore, upron the sereen a rival picture to the British Empire in the form of some 
kind or other of Anglo-Saxon Federation. A rival picture it is, or would probably be, because it is difficult to believe that a federation of the kind would not be a dissolvent of Empire. The younger nations of the present Empire, if brought into some kind of partnership with the great Republicalready, in its own comparative youthfulness and surpassing strength, a most powerful attraction to growing peoples-would tend to become independent members of a loosely bound political system, in lieu of being, as at present, integral parts of an Empire under what Lord Durham well called, 'the stable authority of a hereditary monarchy ' $;^{1}$ and the new organization, having its root in race affinity, would militate against the Empire citizenship which takes no count of race. It is an alluring dream of what is probably impracticable, but which finds some substantial backing in the class connexions to which reference has been made. The whole basis of any scheme of the kind would be race affinity, but as the years have gone on, race affinity between England and the United States has become more and more alloyed by the enormous influx into the American Republic of immigrants not of British and very largely not of Teuton stock. The Americans, too, have in abundance race and colour problems of their own, and it is difficult to picture any time, however distant, at which they would welcome any kind of close combination with an Empire full of 
race and colour problems. Growing friendship between Great Britain and the British Dominions on the one hand, and the Lnited states on the other, we all desire; hut a sober outlowk for the finture stops at that point, and reserves to the british Empire an undivided destiny. 


\section{CHAPTER VIII}

\section{THE NATURAL AND THE ARTIFICIAL}

During the era in England which began with the great Reform Bill,included the triumph of Free Trade, and lasted more or less until the nineteenth century was drawing towards its close, there was in politics and economics what may be called a standard creed, which was more especially the creed of the Whigs, and their successors, the old-time Liberals. This creed was that artificial restrictions should as far as possible be removed, that natural forces are the healthy forces and should be given full play, that State interference should be rare, and that State activity should be directed rather towards repealing old laws than to making new ones. It was a creed which had a most sound basis, because it harmonized with the English instinct in favour of individual initiative, but, being carried too far, it brought inevitable reaction.

The wholehearted professors and adherents of this creed held that the colonies should govern themselves, frame their own tariffs, undertake their own defence, do what they pleased, and shape their own futures. If they declared for independence, such a finale, it was held, would be only logical and according to nature. British emigrants should go where 
they pleased, to British colonies or to foreign countries indifferently, becallse they knew their own business best, and their mosement should not be guided by anything but individual interests. Foree is no remedy' wats a fivourite phrabe, applied nume especially in connexion with Irelind, and meaning that the hand of man is in the long rmu fowerlens ats against the forces of nature. Considering how strongly these views were helel, and how often they are in one form or another still called upon to do duty, when one party or another finds it expedient to appeal to the old firith, it is worth while wo ark the question how fir the artiticial ats opposed to the natural has been in evidenee in the Roman and the British Empires respectively.

Everything made by mam is artificial, whether it is a building or an institution or an Empire. A state of nature is an unclothed world. But hw fill, we ark, does the history of the Roman Empire er of the British Empire bear out the dictum that ferree is 110 remedy, that no hmunth sytem cam be promatment which is not batsed upon hut in at meattel or lans degree runs comnter to nature? If you wath long enough, everything human in time decaly, and the argument caln alwalys be used that it would not hatre decayed if it had not been antificial. This is the kind of judgement whieh is so often patsend upon the Roman Empire. People need to he reminded of the very carefully weighed words in whoh (iib)on refers to the fall of the Roman Fmpire in the We-t. 
'The decline of Rome was the natural and inevitable effect of immoderate greatness. Prosperity ripened the principle of decay; the causes of destruction multiplied with the extent of conquest; and as soon as time or accident had removed the artificial supports, the stupendous fabric yielded to the pressure of its own weight. The story of its ruin is simple and obvious; and instead of inquiring why the Roman Empire was destroyed, we should rather be surprised that it subsisted so long.'1

These words of Gibbon may be taken either as pointing out that the Roman Empire fell because it wasan artificial structure and exceeded natural limits, or as emphasizing the strength which an artificial creation attained. The great difficulty in the case of the Roman Empire is to choose any even approximate dates when it may be said to have begun and when it may be said to have ended. Mr. Arnold, at the beginning of his work on Roman Provincial Administration, lays down that, 'Taking the terms in their widest extent, the Roman Provincial Administration may be said to have lasted for some 700 years, from the final settlement of Sicily after the second Punic war to the apparent destruction of the system by the barbarians,'" that is until the fall of what is commonly known as the Western Empire in A.D. 476. At least, he gives to the Provincial Administration a

'Decline and Fall, 1862 ed., vol. iv, p. 403: 'General Observations on the Fall of the Roman Empire in the West.'

${ }^{2}$ Roman Provincial Administration, p. 1. 
dife of 500 veatrs. 'The Eatstern Empire or the Eastern half of the Empire long outlived the Wentern half and, in Freenam's words, 'Kept the political tralition of the eleler Empiro mblrokens." Howerer we lewh at it, the Roman Empire, in one form or another, Was very long-lived, and side hy side with its long life, we have to set the filet that it wats a mont artifiedal ereation, the one artifiedal ereation which plated

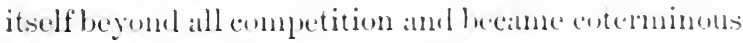
with the eivilized worlel. It wats biscel on force, am it stamls out to all tine as contrulieting the dietum that foree is no remedy. At the sante time, while the Roman Empire Was essentially antifiedal, it male what maly be called concessions to nature. 'Thomgl differences of ratce and nationality were in the main werridden or innored, the great reot differences between Eist and West wats reeognized, and the Eatst wats left to be Cirecelin in civilization rather thatn Roman. 'Though the Empire wats the reant of conquest, the confuent wits to al lamge extent the result of natural exprasion. The limpire serew hy constant and enotinuens anceretions of aljoining territory, not by alequirition of lamels wholly removed from the eentre of life. Further, with smbe exerpe

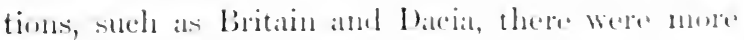
or less natural homblaries to the Empres whill

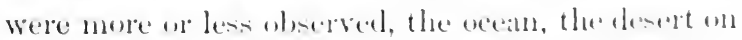
the south, the great rivers of the lihine, the Linulue, and the Euphrates. Within the Empire. ton, in

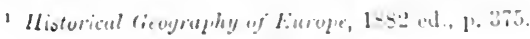


CHAP.

Mr. Arnold's words, 'the Romans showed greater power of assimilation than has been shown by any other conquerors,' and they 'were not cursed with the passion for uniformity.' 1 They actively encouraged municipal institutions, they tolerated local creeds, their armed forces gave peace, and peace made for natural conditions under a military despotism, which was an artificial régime.

In a previous chapter it has been attempted to show that the British Empire has owed more to the initiative of private individual citizens and less to the State than was the case with the Roman Empire. That is another way of saying that our own Empire is not such an artificial handiwork as was the Roman Empire. Inconsistent, illogical, full of contradictions and diversities, the British Empire gives every evidence of having in great measure grown at will, as opposed to being made to order. Men argue, therefore, looking at this Empire and considering how it has come into existence, that what is lasting is based on nature, and what is transient is the outcome of State interference and human will or caprice. To illustrate how dangerous generalizations of this kind are, we will take the case of one great Province of the British Empire, Canada, and examine how far Canada of to-day is a natural or an artificial creation.

Canada was first colonized by the French. Its beginnings were, in the words of Francis Parkman, those of a mission and a trading station, and it was

1 Roman Provincial Administration, pp. 5, 22. 
not until the reign of Louis XIV that it berame in the true sense a colong. 'The object of lonis XIV" and his advisers wats to reproduce Fimm in Americal, to make Cantulil in firce, as in namm, Now Finnee. With this object the forms and contums of the whl world were transplintod intu the new, and a femdal system Was created on Americam sril, amd rame intw being not as a historic ermoth, hut hy urder of a despotic king. An ignorant pepulation, spromer from a brave and aletive ratee, but trained to subs jection and dependence thromgh enenturies of fomblal and monarchical despotimn, wats planted in the wilderness by the hame of anthority, amd toll to grow and flourish. Artiticial stimulants wereaplelied, but freedom wats withleld." Parkman anes on to tedl us that "the Canalian Government was exientially military', and that the pepulation in larere meatsure sprang from soleliers and was recruted ly dishomeded soldiers. For instaner, some complunies of the famous C'arignam-salieres regrment, which hat been sent on serviee to Canada, were disbanderl in ('antulat, the oflicers were convertenl into serienions, and the

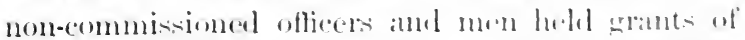

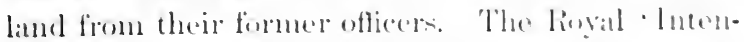

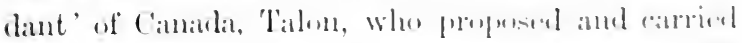

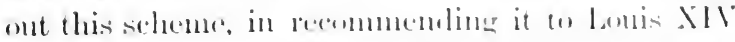
and his ministor, ('olbert, gatve limman military colonization ats a proendent," and it hats hand pointed

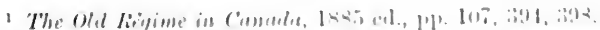

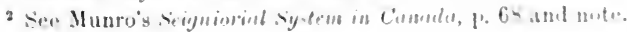


CHAP.

out in a previous chapter that French settlement in Canada had much in common with Roman colonization. Canada then, or rather the Province of Quebec, was settled by the French on a purely artificial system, the only natural element in it being that the colonists were given the same conditionsartificial conditions-that they had known in the Motherland. Lord Durham's verdict upon the French Canadians in his report was that 'They remain an old and stationary society, in a new and progressive world ', ${ }^{1}$ and he recommended the fusion of Upper and Lower Canada in order to absorb this old-world conservatism of French Canada. The seigniorial system was eventually abolished, but French Canada still bears witness to the strength and permanence of a colonization carried out on purely artificial lines. As part of the British Empire, French Canada has been, in spite of Lord Durham's recommendation, allowed in the main to take its own line of development, and the result is that French Canadians to-day are more nearly allied to the French of the eighteenth century than to the French of modern France. In other words, a colony which owed its inception to the will of a king and was organized under hard and fast rules made by a king, which was artificial in every sense, except that the artificiality was reproduced from the old home, has held with singular tenacity to its original character.

Now, if we turn to the boundaries of Canada, we

1 Lord Durham's Report, 1912 ed., vol. ii, p. 31. 
can hardly find any other country in the world whose limits are so obriously artificial. There is nothing whatever natural about the internationst boundary between C'mamla amd the Lnited States. For a long distance, it simply follows it parallel of latitude. At some pmints, as in the northeat, where the Maine bumblary question in pitst veatrs nearly brought on war between fireat britain ambl the United States, of in the region of the Latke of the Woods, the boundary is almost aroterfmely contrary to natture. The whole lime is the result of treatios mande before the geography wats kumw, of subsequent interpretations of the treaties, and of political compromises. The grambal dolimitation of this unnatural amel incomvenient bumblary left Canada, or rather British North America, the rery antipodes of a compalet territory. It wist in short

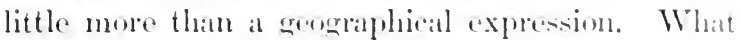
wats the agency which gatse it cohesion and the beginning of a national existence? The answel' is railway, the Interenlonial ratilwaty whoh wat the condition of the Maritime Provinese federating with

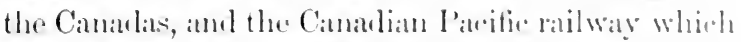
was the condition of British ('olumbit entering the Dominion of C'anarlat. No single work of man in any fart of the werlel at any perient of the world history hats so obviously and dirently antributod to the making of at nation as the tramsentinental railway in Cambla. That Cimamla torlaty is al Dominion from sea to seat is not the pesult of natture. 
it is the result of human handiwork, though behind that handiwork, it is true to say that there was the instinct of nationality.

This instinct, if not called into being, was and is most powerfully nourished by the neighbourhood of the United States, of an always present, in the past not always friendly, power, not separated by any natural boundary and possessing all the attractiveness of strength, wealth, kindred race, and language. It was in order to resist this attraction that Lord Durham recommended the union of British North America, so that the danger of being absorbed into the United States might be met 'by raising up for the North American colonist some nationality of his own'.1 Canadian statesmen feared that Canada might be absorbed not only by conquest but, in the alternative, by peaceful means and financial pressure. This was in large measure the origin of the policy of high protective tariffs, which was advocated and carried by Sir John Macdonald as a national policy, and which has held its ground to the present day as being a national policy. In other words, once more the artificial has, with a view to preserving national existence in Canada, been set against the natural. From first to last Canada is an instance of a nation growing up not on the lines of nature but rather in transgression of those lines. The original colonists were planted out by rule, they have never amalgamated with the race which came in after them so 
that there should be race cohesion through the whole Dominion, that Dominion has the nost unnatural boundary, the cohesion which it has attained is the direct result of serentitic invention, and nationhood has been saleguarderl hy the nort artificial of all human devires, at Protective 'laritl. Yet Canada, thus constituted, hids filir to bearl the British Empire amd has alrealy aldieved a high place among the proples of the world.

In order to aroid as far at posible matters of eurrent controversy, it is mot propmeded to chter mpon any detailed diseusion in this bouk of thr merit. and demerits of preferential tariffs. It maly well or platsibly be arerued thatt the great natural resentures of new combtries are the seereet of their history, thast where land is abmolint, fopulation small, and means of living plentiful, politieal experiments ane not so dangerous and lammful ats in matumed rommtmities. and that, therefore, the rent of the matter is atter all in the natural ame not in the antifirial. Free lramle. represented in England the trimmph of the selumel aceoreling to nature, and Free 'Trate went hamel in

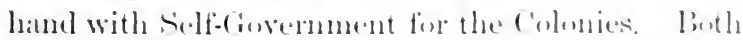

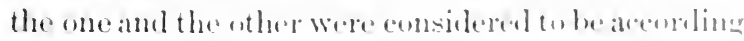
to nature, and it was held that natture shomlel mot he

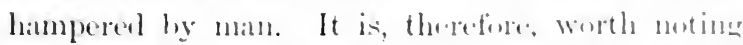

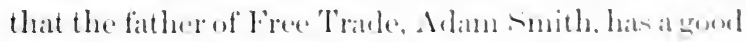
word for the Navigation A.ts, whith e-perially embodied the old mereantile systems. As lefenese", he writes, is of much more impurtanes than 
opulence, the act of navigation is, perhaps, the wisest of all the commercial regulations of England.' 1 It may be pointed out again that if, as has been contended in a previous chapter, the family analogy gives a true representation of the relations that exist or ought to exist between Great Britain and the SelfGoverning Dominions, Imperial Preference, the root principle of which is membership of the same family, is in its essence far more natural than Free Trade which draws no distinction between members of the family and aliens. Further, it is most noteworthy that the young nations of the Empire, having been given self-government, in other words, having been set free from artificial restrictions imposed by the Mother Country and left to develop on natural lines, have, from the instinct of self-preservation or other causes, shown a strong preference for the artificial as opposed to the natural.

The case of Canada has been quoted. Let us take Australia. The doctrine of the school according to nature is that goods and men should as far as possible come and go at will without artificial restrictions. Australia is an island continent colonized from Great Britain, and Great Britain very wisely obeyed the call of nature and threw the reins on the necks of Australians, giving them their heads in the race for destiny. The result has been that they have turned in the making of their nation to the artificial, to high tariffs and to race exclusion. There

1 Wealth of Nations, Bk. IV, chap. ii. 
are very good reasons in either case; and Aurtralians are the rightful keepers of the future of Auntralia and the best judges of Australian interests. But here we have a curious contrist betwen the lioman and the British Empires. The lioman Empire was a trimmph of the artifieial, a military despotions. Yet in this artificial whole, and to sone extent beanter. it was artificial, that is to sily becatse forer prevalidel and meant companative peatren, natural anditims prevaled to a considerable rextent in thin lorality and in that. There wats all absener of politival firendem, lut there was no want of liviner aleeromeline to nature. Especially it shombl be moted that muler this

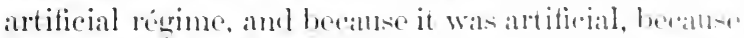
it was male to oreler, and the will of the cientrial Government was imposed on the patts, there wats, in spite of consilerable variety of taxation, to which

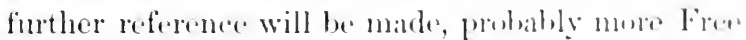
Trade and fewer Customs barriers in the lioman Empire than in the British Empire, which is thente come of Self-Government and Free Trate combined.

The British Empire has, it must be repeated. ham in its composition much more of the natmal amel much less of the artifielal than wats the rase with the Roman Empire; and in the enmedse of Briti-le statesmen in the nimeternth century the natural pre. vailed to an extent to which it would be diftionle to find a parallel. But in this kmpire, ame in thone parts of it where the intention wats most rearly. shown that development should he on matmal lines, 
there the world has learnt the lesson that artificial restrictions commend themselves to the instincts of young peoples, who do not feel safe in entrusting their future to the course of nature. They may be wrong; they may be short-sighted and erring unwittingly against the light; but the fact remains that, while England through obedience to natural laws has given that freedom which has enabled the Empire to be a nursery of young peoples, the young peoples judge that they can only fulfil their destinies as nations by calling in the artificial, not merely to supplement, but in large measure to counteract nature.

Closely akin to the antithesis of the natural and the artificial is that of facts and appearances. Do not tell me what this man or this thing looks like, the whole question is what he or it is. That is a very common form of expression, which commends itself as being downright, going to the root of the matter, and indicating the view of an honest, straight-thinking man. It is a most dangerous view, if applied wholesale to Empires.

In his Essay on the Government of Dependencies, at the conclusion of the chapter on the 'Advantages derived by theDominant Country from its Supremacy over a Dependency', Sir George Cornewall Lewis discusses the 'supposed advantages flowing from the possession of dependencies, which are expressed in terms so general and vague, that they cannot be referred to any determinate head. Such, for example, 
is the glory which a country is supposed to derive from an extensive colonial Empire. Ho dismi-reon the subject by saying "that a nation derives no true" glory from any possession which produces no asignable advantage to itself or to other communitios". that, if a country receives no alceess of strength, nu, commereial advantages and so forth form at depente deney, to be set against the evils of dependener, : $\rightarrow 2 x \cdot h$ a possesion cannot justly be called shorians." 'The. writer, though he published his bok in 1511, after. Lomed Jurhamis lieport had seen the light, concevived of a colonial Empire as consisting solely of depente dencies. He hat no vision of a system entaining alike dependeneies and relt-(inserning lominions, and he uses the word glory to emphasize his arenment that appearance without falet behind it is nothing worth. Even glerg is something more than vainglory. A nation loes net win glory without thereby deriving some perminent result, gond ol bid, upon the character and the thousht of its members. But if for the word ghory we substitute prestige or eredit, we realize that appearances may be in themselves substantial fiuts. The worl prestige has been attacked-much as Cornewall Lawis attacked glony-as being a foreign worl impenting an idea of bombast, which is, or ought to be, forrign to Englishmen. Credit, on the contrary. is well known in matter of firet eommereial cireles. A merehant trades in great measure on erolit. It is

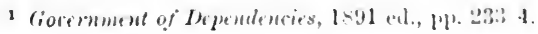


CHAP.

possible that he may have little or no actual cash behind it, but if he possesses credit, in other words, if he is believed to be a man of substance, he can carry on transactions which would otherwise be out of his reach. Appearance in this case is an actual fact. Similarly, nations also largely live on credit, they are largely judged by appearances, even more so than individuals, because they are less liable to daily close inspection from experts.

Further, the more competition there is, the more important appearances are. The Roman Empire for the greater part of its existence had no competition, it was in the position of a successful monopolist, and the Romans were so assured in their position that appearances mattered less to them than to us. Yet it can hardly be doubted that their Empire would not have held out so long, in its time of decay, had it not been for credit and appearance exceeding the actual facts of the case. The shadow of the Roman Empire was something without the substance. The Empire looked stronger than it really was in its later days, and the Roman name alone was an asset. Our Empire is far from holding the unchallenged position which the Romans so long enjoyed, and appearances are proportionately more important to us. Let us suppose that, as a matter of fact, we derived from the Dominions and dependencies beyond the seas no advantage whatever in commerce, or for defence purposes, or in any other direction. Still the fact would remain that the British Empire 
looks large on the malp; that the world in Lenerabl, the man in the street, judgess of men and things ly what they look like, not by what they are; that wor

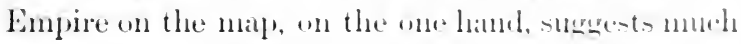
to be taken by those who are preprired to gre to war, and, on the other hamd, gives an alynearanee of strength which would be wholly wanting, if lisealt Britain hath no overseal pussessions. In shert, these. who try to estimate aright the value of whe Empire will never leave ont of sight the impors. tance of aplearances, which atre even mure potent in days like our own of widely spreat half knowledge, thim in former times of fairly semeral ignorance.

'There is set another sile to this subjowe of

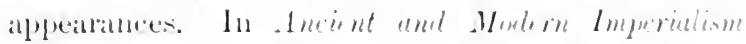
Lord Cromer, like Mr. Armolel who hat been y powent

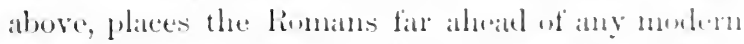
nation in power of assinilating subjont ranes. They hadd, he thinks, at much eatsien tats tham hat fithen to the lot of molern Empires, for they wrete nut eonfronted by the ditlicultien of eolenr and religinn which are obstateles to us. At any rate, they wore more successful in liomanizing other ratees than the nations of modern burope have been in ansintilting their subjeets. Among these molern natione the

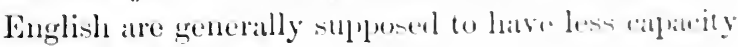
for atssimilation thatn, at any ratte, the Lattin proples. Lord Croner holets that "our habits ate insulatr, and our social custons renter us, in comprarison at 
all events with the Latin races, somewhat unduly exclusive'. On the other hand, he gives as the result of his almost unrivalled experience, 'the conclusion that the British generally, though they succeed less well when once the full tide of education has set in, possess in a very high degree the power of acquiring the sympathy and confidence of any primitive races with which they are brought in contact.' ${ }^{2}$ Similarly, Mr. Arnold writes of the Romans: 'Rome was extraordinarily successful in civilizing barbarians, not perhaps so successful in dealing with races already of a high type.' 2 In comparing the English with other modern Europeans in this matter of assimilation, Lord Cromer finds that while the English are wanting in 'social adaptability, in which the French excel', they have, on the other hand, 'a relatively high degree of administrative and political elasticity.' 3 These views may be summed up as follows. The Romans were more successful in assimilation than any modern nation, partly because in the Western provinces a larger proportion of their subjects were in a primitive stage and, therefore, ready for the melting pot than has been the case in modern Empires. The higher and more civilized races are, the more difficult they are to assimilate, because they are more stereotyped; and, lastly, assimilation has two sides, what Lord Cromer calls

1 Ancient and Modern Imperialism, pp. 74-5.

2 Roman Provincial Administration, p. 6.

s Ancient and Modern Imperialism, pp. 84-5. 
'social atliptability', and what he ealls 'alministrative and political clasticity'.

Now if the English, by eommon consent, have been wanting in 'soedial adaptability", it is beeallse. they are more indifferent thin other peoples to appearances. If, by common consent, they hatre been successful ats administrators and makers of Empire, it is precisely for the simne reatson, that they have disregarded appearances, eatred little for logre and uniformity and dealt with ficts. But in proportion to the suceess brought by aldministrative anel political elasticity is the drawbatek arising finem absence of social athetability: for the better the work done by the makers, and the more they hatre ratised the peoples under thems, and given them colsesion and civilization, the mene there penples, having secured the sulstance, lowk fire and alymente appearances. Consequently, the further the enenstructive work of the Empire is carried, the more attention alpeatrances ought to receive. Nor danes the question of alpeanances eneern only the relatting of the british to andented ratces. It conterms the relations between the different gromens of ant win race. The British from begend the seats tow often find the British in the home land reservent and uncongenial. The home Britur cinn handly he (on) sidered sucessful in alsimilating the armetat briton. 'The reason ustatly given is that the home Britum is stiff and formal, in other words, what is enenerally classed undere the term antiticial. But the truel 
explanation is that the home Briton is too natural, he does not care for appearances or estimate them at their proper value. If he could really become more artificial, he would seem more natural. In short, if we desire to keep goodwill among the nations of our Empire, we must pay more regard to appearances. 


\section{('HAPTER IS}

\section{THE TWO EMPRLS}

How fin was the Roman Empire, and how far is the British Empire, one Emples:

It is not ealoy to gattlee the inswere to the question as regands the Romm Empire from thase who hatse written with inthority on the subjeet. Cornewall Lewis silys, 'The regulations reopecting the appoint. ment, pwers, and rank of the homan governors. and the duration of their office, constituted the only part of the provineial institutions of hine wheh were uniform throughout the Provinces. In all wher respects there wat the utmost diversity in the provincial governments. It was the general puliey of the Romans not to make more changes in at eenquered territory than were neessary fin reelucing it to complete subjection." $\mathrm{Mr}$. Amolel writes, 'It is exceudingly difficult in discuming the Provintes of Rome not to talk of them ats a whole, and ats al fixal whole. But, in truth, the Romin world is at worth continually growing, developing, (hamering, alwatys tending to a uniformity but never fully reanhe it. The difference between bist and Wint is never obliterated, and at last vietorionsly atserts itoelf.

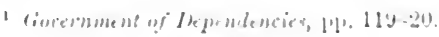

K: 
The Romans showed greater power of assimilation than has been shown by any other conquerors; but even they could not assimilate a civilization like that of Greece, which was in some respects superior to their own. So the Greek East was not organized, after the strict type of the Roman Province, into colonies and municipia until a late date.' But he goes on to note, 'the large and increasing element of unity. The administration was everywhere of much the same type.' 1 Professor Bury tells us that 'The Roman world was a complex of different nations and languages, without a really deep-reaching unity, held together so long by the mere brute strength of tyrannical Roman universality, expressed in one law, one official language, and one Emperor -a merely external union. Naturally it fell into two worlds, the Greek (once the Dominion of Alexander) and the Roman; and this natural division finally asserted itself and broke the artificial globe of the Roman Universe.' This passage emphasizes the artificial character of the Roman Empire, a point which has been discussed in the last chapter ; and it seems at first to suggest, as Mr. Arnold's words also suggest, that the Roman Empire was two Empires in one; but Professor Bury goes on to negative any such conclusion. 'The actual territorial division between the sons of Theodosius did not theoretically constitute two Roman Empires'; and in the Preface to his volume, he is at pains to con-

1 Roman Provincial Administration, pp. 5-7. 
tradiet the commonly received dortrine that the Empire broke up into an Eastern and a Western Empire. "Nothing can be easier than to apprehend that the Romin Empire endured, one and undivided, however ehanged and dismembered, from the first century 13.6. to the fifteenth century ... I.' ' His view is borne ont by Professor Freeman words quoted in the list chapter."

Tho Roman Empire was necessarily very different in one era from what it was in another. After. Diocletian, for instance, had handled and recast it, it was widely different from the Empire which Augustus left behind him. It may, therefore, well be objected to any comparison between the Roman Empire and the British Empire at the present day, that the Roman Empire was one thing in one century and another thing in another, just as the British Empire at the end of the nineteenth century was poles asunder from the British Empire at the end of the eighteenth century, and still more at the end of the seventrenth century, so far ats it then existed. But the objection is not wholly a valiel one. The true conclusion seems to be that, in spite of the manifold changes which time womght, in spite of the statesmanlike discenard for uniformity which the Romans showed in their hest diys, in spite of their toleration of local creeds and usiges,

'A History of the Later Romun Empire, vol. i, 1. 36, and Preficer, p. viii.

:Above, p. 115. 
the Roman Empire, so far as it was an Empire, that is so far as it was a political organization, was from first to last one Empire. If it was artificial, 'a merely external union,' at any rate it was all artificial. It was one, whichever way we look at it.

It was one in authority, even when emperors were multiplied. The imperium, we have seen, was one and undivided. At head-quarters, at any rate in the early days of the Empire, the Emperor had all the powers of the State in his own hands. He had no departmental ministers, recognized as such, no Foreign Secretary, no Secretary of State for the Colonies. ${ }^{1}$ The nearest approach to any division of authority was the allotment of the Provinces made by Augustus between the Emperor and the Senate, but the real power remained with the Emperor. In each Province again, when the Empire was at its best and strongest, the governor was supreme in all respects and combined all powers. 'The special feature of the Roman system was its union in one single head and hand of functions which the modern system takes care to separate.' 2 It is true that the time was when in the British Empire also the governor of a colony was actually, as he still is nominally, commander-in-chief, when

1 Mr. Arnold in Roman Provincial Administration, p. 133, in writing of the early Roman Empire, says, 'The Emperor was assisted by his Cabinet; and his secretaries for the conduct of the different branches of the administration became ministers of state,' but no authority is quoted for this statement.

2 Arnold, l. c. p. 54 . 
he had judicial funetions, inasmuch as his Executive Council was a Court of Appeal, while he alway's was, and in the Crown Colonies still is, directly responsible for the finances. It is also true that, in the later dilys of the Roman Empire, the command of the troops in those Provinees in which legions were stationed, was separated from the charge of the Civil Administration; so that it might be argued that the position and powers of a governol of a Roman Province did not wildely differ from those of a governor of a British Crown Colony, if they are compared at corresponding epochs of history. But it was not so. The perfection of the Roman system wals union of all aluthority in one person. The perfection of the British system is entrusting different functions to different hands. In its essence the Roman system was an undivided despotiom. Mr. Arnold sums it up in the words, 'Rome liad undertiken an impossible task, that of ruling an immense Empire without federation and without a representative system, where the sole sources of power were the Supreme Central Government and the army.' ${ }^{1}$ It seems strange to saly that the task was impossible, when it wats performed so long and so efficiently, and it hats yet to be proved in the history of the world that a military despotism in Roman hands was not ats long-lived ats, or more long-lived than, sounder systems in other hands. But there will always be two opposite points of view

'Romen Protincinl Alministrutimn, p. 169. 
from which the Roman Empire can be regarded, one which seeks for the reasons why it declined and fell ; the other-surely the wiser one-which tries to discover why this Empire lasted so long. From either point of view, however, it can be summed up that in the matter of authority the Roman Empire was one, the result of a single military despotism.

It was one in kind, too. Great as the Empire was, it hardly reached, in its southernmost limits, in Egypt and Arabia, to the Tropic of Cancer. The North of England or the South of Scotland was its northernmost bound. It took in East and West, but only the Nearer East, and the West only in Europe and North Africa. It was in the main a Mediterranean Empire, all or nearly all within the temperate zone, not concerned with lands of great cold, not concerned with the Tropics, not concerned, as has been said, to any appreciable extent, with coloured races. The Provinces differed one from another in this respect or in that. The Greek East, as a whole, differed from the Roman West. But all the Provinces in East and West alike were of the same general type. All bore the hall-mark of town life. All were thoroughly conquered; all were partially colonized; ' and, as the franchise becomes more and more extended, the Roman law comes to be the only law over the whole Empire.' ${ }^{1}$

${ }^{1}$ Arnold's Roman Provincial Administration, p. 32. 
It was one anain in revenue matters. 'The receipts from the taxes, other than octrois and municipal taxes, all went to the Imperial Treasury, as we should now call it, including (as long as the provinees were divided between the Senate and the Emperor) both the aerarium and the fisens. It is true that, not being eursed with the passion for uniformity', and very probibly acting on their favourite principle of divide et impere, the Romans allowed considerable varieties of taxation as between the different provinces. Even the Portorial, or customs duties, were not uniform. In this respert the Empire never formed a united whole, but was divided into a number of larere customs districts, within which the scale of the tax varied considerably.' 'The customs duties were as a rule anl ralorem duties, but the rate valried. Five per cent. was charged in sicily on imports or exports, $2_{2}^{1}$ per cent. in Gaul or Asia. The duties were levied fint revenue, not for protective purposes, but we have an indication of protective duties as against the foreigner, in that 'the Egyptian ports were, if not directly barred, at any rate practically closed, by differential custom dues against Arabian and Indian transports :." No doubt taxation within the Roman Empire was far from uniform, hut for diversity of tariffs the loman provinces would not compane with

'The Imprial Ciril Serrice of Lome, ly H. Mattingly (Cimbrillece Historical Essays, No. xviii), 1910, p, 10.

2Mommsen's Pmrinces of the lioman limpire, vol. ii, p. 299. 
the British Crown Colonies, let alone the self-governing Dominions. The reason is that the tariffs in the different British colonies or dependencies are, with some few exceptions, as when British Free Trade may have dictated to India, arranged in the interests of each colony or dependency. The Romans, on the contrary, from beginning to end, never let go the principle of tribute to the central power. The provinces were to pay the cost of their Government, but the surplus was to go to Rome. Financially, as in other respects, the Empire was one.

Bacon's view of the Roman Empire is specially interesting, because he lived just at the time when England was on the threshold of her Empire work. Roman colonization, it has been seen, was mainly military colonization, but what Bacon found to admire in the Romans was the extent to which they went beyond the mere planting of garrisons in conquered countries. 'I find,' he wrote, or rather pleaded, 'by the best opinions, that there be two means to assure and retain in obedience countries conquered, both very differing, almost in extremes, the one towards the other. The one is by colonies and intermixture of people, and transplantation of families ... and it was indeed the Roman manner; but this is like an old relic, much reverenced and almost never used. But the other, which is the modern manner, and almost wholly in practice and use, is by garrisons and citadels, and lists or companies of men of war, and other like matters of 
terror and bridle.' " The Roman Empire, in his view, was the result of conquest, hut of conquest assured by colonization and widening of citizenship, whereby, to quote again words of his which have already been quoted, 'It was not the Romans that spread upon the world, but it was the world that spread upon the Romans.' " Up to Batcon's time Empire had been synonymous with conquest, and the Spanish conquest of America, which was betore his eyes and within his ken, must have seemed another illustration of overrumning a world. To him the Romans stood out as being more than mere conquerors. Where they conpuered, they colonized also. 'Ubicunque vicit Romanus habitat.' ${ }^{3}$ But Bacon's words bear witness to the fiact that this great Roman Empire was one, and one only. All of it was the result of conquest; in all of it there was something more than conquest. No part of the Empire contrasted with another part, as being different in kind, it was all one Empire.

What would Bacon have said of the present British Empire? He could only have come to the conclusion that it is two Empires in one, that this fact marks it out from all the Empires of the world. Before enlarging upon this feature of duality in the British Empire ats contrasted with the unity of the

1 'Catse of the Post Nitt of Scothum,' Apealding's edition, vol, vii, 1. 661 .

" Of the True Greatness of Kingdoms and Estates,' spedting's elition, vol. vi, p. 448.

s Suneca, Dioloymes, xii. T. 7 . 
Roman Empire, there are two points to be noticed which are at least interesting for the purposes of comparing ancient and modern history. We are taking what was incomparably the greatest Empire of the ancient world side by side with the greatest Empire up to date of modern times, and we have seen that the greatest ancient Empire was one in authority and in kind, all in the same zone, in the main continuous, compact, and practically coterminous with civilization. Now the most remote province of this great ancient Empire was part, not all (for the Roman province of Britain at no time included either Ireland or the Highlands of Scotland), of the motherland and centre of the great modern Empire; and this modern Empire lies almost entirely outside the limits of the ancient Empire. Gibraltar, Malta, and Cyprus were within Roman bounds, and Egypt, though not part of the British Empire, may be said to be under British hegemony or protection not very far removed from its status in regard to Rome under the later Ptolemies, before it definitely became a Roman province; but otherwise the whole of the British Empire is in parts of the world which Rome never knew and which never knew Rome. Moreover, we have the interesting fact that, while the Roman Empire was all in one zone, which contributed to its unity, that zone and the Roman part of it has become, beyond all other regions of the world, split up into separate and independent nations. On the other hand, where England has overflowed 
into temperate zones like her own, she has found them wholly outside Europe, and very largely in the most remote part of the worlel, in the far sonth. The contrast between the Roman and Britisle Empires is illustrated and emphasized, if it is borne in mind that they are in the main geographically exchsive of each other ; and yet we have this curious half-link between them, historical and geographical, that the most distant province of the Roman Empire, ent off by the seat from the main body, beeme the heart and nuclens of the modern Empire.

The second point concerns the diversity of the British Empire as compined with the mity of the Roman Empire. What was it that mate the Roman Empire one? The answer, which hats alleatly been given, is loss or absence of freedom. It becante more one in proportion as liberty disippeared. In the same proportion the British Empire has beeome less one ats freedom has grown. The Roman system produced a structure which lasted for almost if not quite an unparalleled time, but we are told to believe that it lasted, as an old oak lists, more dead than alive, and perished because the somee of life, which is freedom, was dried up. It is for the future to show-and herein lies the intense interest of the British Empire-whether the diversity in that Empire, being born of freedom, will preserve the life of the whole, whether the true road to unity is through diversity, because diversity means freolom. 
The British Empire, it has been suggested, is two Empires in one. It falls into two wholly different, and in the main, mutually exclusive spheres, which may be distinguished as the sphere of rule and the sphere of settlement. It is obvious that these two spheres differ wholly in kind. The sphere of rule is an Empire over tropical lands and coloured races. There the English have come, not to settle, but to administer and to rule wholly alien peoples. The sphere of settlement is an Empire of dwelling-places in lands which are outside the tropics and inside the temperate zones. It is an Empire not over but in the hands of white races, mainly our own British race. The English have come there to settle in the lands, to make them British, to rule the lands, it is true, but mainly to rule themselves. Reproduction is the key-note of the sphere of settlement, governance is the key-note of the sphere of rule. Of the sphere of rule it may be said that the English are in it but not of it; of the sphere of settlement that the English are both in it and of it; and this difference is illustrated by the fact that the self-governing Dominions are all British soil, all lands held in complete sovereignty and ownership, whereas a considerable proportion of the sphere of rule is technically only under British Protectorate.

In kind, then, there are two British Empires, not one. How does it stand in the matter of authority? 'The whole of the British possessions are the King's dominions, whether they are in the sphere of rule or 
in the sphere of settlement. It eamnot be ton strongly emphasized that allegiance to one King, to one Crown, is the greatest of all bonds of mion in the British Empire. Nor ean it be overlooked that the bond is not merely to the Crown as representing the State or the race, but is also a personal tie to the King for the time reigning, all the stronger when, as in the ease of his present Majesty, the reigning King has in a mique degree personal knowledge of all parts of his dominions. This loyalty to a person is liable to be underrated. One of the great mistakes made by the English after the conquest of Canada wass to overlook the firct that French-Canadian loyalty had been to persons rather than to institutions; and at the time wise governors, like Carleton, emphasized, though with little or no result, the importance of making the Canadians feel that under British rule they were still the King's men. Especially is this personal side of the monarehy to be borne in mind in regard to Eastern races, and herein lity the statesmanship of ereating the title Emperor of India. But taking the Crown as the embodiment of authority, how firl is it one? It has been said that though Roman Emperors were multiplied, the authority was one. There is but one Crown in the British Empire. Does it represent undivided authority? His Majesty the King is Emperor of India, he is the constitutional King of Candala ; he is the Ruler of India in a wholly diflerent sense from that in which he is King of Canada. This means 
one person representing two kinds of authority, as opposed to the later stages of the Roman Empire when there were more Emperors than one but only one authority. But this statement does not quite meet the case. There is division of authority, but the root of the division is not, so to speak, in the Crown itself, it is in the advisers of the Crown. Great Britain has acquired an Empire; part of that Empire Great Britain rules, the other part is not ruled by Great Britain, but is a reproduction or reproductions of Great Britain. His Majesty is the constitutional King of Great Britain. Therefore, both as regards the United Kingdom itself and as regards the parts of his dominions which are ruled by the United Kingdom, he is, whether as Emperor or as King, advised by the Ministry of Great Britain. His Majesty is the constitutional King of each of the reproductions of Great Britain, that is to say, of each of the self-governing Dominions, but here, through his representative in each Dominion, he is primarily advised, not by the Ministry of Great Britain, but by the Ministry of the Dominion. In this lies the division of authority, which did not exist in the Roman Empire, even when the Roman Empire had no longer a single head.

The general statement has been made that the British Empire is two Empires in one, each Empire outside the other. It is a statement which is broadly true, sufficiently true to give a fairly accurate bird'seye view of the whole. But, as a matter of fact, in 
the first platee, the two spheres of rule and settlenent are not quite mutually exclusive; and, in the second place, each of the two spleres contanis so many diverse elements, that it maly be argued that the British Empire is not merely two Empires in one but many Empires in one. A few words will illustrate each of these two points. The sphere of settlement is not purely a sphere of settlement. In other words, the Self-Governing Dominions are not exclusively inhabited by incomers of the white races. All of them had once aboriginal inhabitants. The aboriginal natives are now extinct in Newfoundland and Tatsmania. In Canada, and still more on the continent of Australia, they are-from any other than a philanthropic point of view-a negligeable quantity ; but in New Zealand the Maroris are a very appreciable element in the population, and in South Africa the coloured men largely outnumber the white, making the native question the greatest of all South African problems. Nor are the Selt-foverning Dominions all outside the tropies. The South African Union tonches the tropic of Capricorn in the north of the Transvaal. The whole of the north of Australia is within the tropies; and Australia has a tropical dependency in Papua, as has New Kealaud in the Cook Islands. If, on the other hamd, we turn to what has been styled the sphere of rule, wo find that, so far from all of it being included in the tropies or all of it the home of eoloured races, the Mediterranean eolonies are within this sphere, so are 
the Falkland Islands, so is Bermuda, which last colony is largely self-governing. If we go inside the tropics again, to the West Indies, here are tropical islands which have been the scene of British settlement since the seventeenth century, and which had a large measure of self-government long before any one of the present Self-Governing Dominions, except Newfoundland and the Province of Nova Scotia, had any connexion whatever with the British Empire.

Within each of the two spheres the diversities are great. In the sphere of settlement not only has South Africa a native problem, which Canada and Australia have not; not only are Canada and South Africa differentiated from Australia and New Zealand in that from the beginning of colonization Canada had the French element in its white population and South Africa the Dutch; but in this very respect in which they differ from Australasia, Canada and South Africa may be compared and contrasted in various ways. For instance, the French Canadians are much more concentrated in one part of the Dominion of Canada than is the case with the Dutch in South Africa, and again the only political liberty which the French Canadians have known in their history has been in the form of selfgovernment on the British model and under the British flag, whereas some of the Dutch in South Africa have known political liberty in other forms. It is important to emphasize that the Self-Governing Dominions differ so greatly from one another, that 
they have diverse elements, white and coloured, in their populations, and conditions varying according to latitude and longitude and land and seal ; for one main cause of inacenrate thinking on the problem of the relations between the I)ominions and the Mother Country is that that problem is usually presented is one between two parties only, the Dominions on the oneside, and the Mother Country on the other, whereats we have not to go firther than the Imperial Conferences to find abundint illustration of the fiact that the divergence between one Dominion and another is ats great as or greater than the divergence between any one of the Dominions and the Mother Country.

Has Australia, for instance, more in common with South Africa or with the United Kingdom? In common with South Africal and as agrainst the United Kingdom, it has space and youth. It has its bush als South Africa hats its veldt, it has not a few similarities to South Africa in climate, products, water supply or want of water, and so forth. Both are young communities in a somewhat similar stage of derelopment; they will to some extent compare in numbers of the population. On the other hand, Australial hats practically no native problem, and in race and all that race brings with it is ats British ats England herself. How can the problem of Empire be rightly presented as one between Great Britin and Australia, or one between (ireat Britain and South Afriea, and never as between Australial and south Africa, and so forth of the other Dominions?

$$
\mathrm{L}:
$$


To speak and write and think of the Self-Governing Dominions in their relations to the Mother Country as a homogeneous whole leads to misapprehension of the difficulties and the possibilities of the British Empire, but it is still more misleading, though it is hardly so common a failing, to overlook the vast difference between the various dependencies which are included in the sphere of rule. What could be more different than Gibraltar from Fiji, the Malay Peninsula from the Falkland Islands, India from West Africa? It has been seen that some of the West Indian islands, Barbados for instance, with its long record of British colonization and representative institutions, have historically a claim to be placed in the sphere of settlement. India again is on a wholly different plane from West Africa, and is so completely organized as a unit, so equipped with a complete administration, that it has been a question whether it should not be one of the parties to Imperial Conferences. Further, there is this interesting and notable feature in India that as Great Britain has colonized the Dominions, so India, through the operation of the indentured coolie system, has colonized not a few of the other tropical dependencies of the Empire, Mauritius, Trinidad, British Guiana, Fiji. It has, in short, to some extent supplemented Great Britain in the British Empire by playing the part of a Mother Country.

But if we take the case of India, as being the British dependency which is on the highest plane, 
we shall find that there is in real truth at great gulf fixed between the sphere of rule and the sphere of settlenent, and that gulf to some extent eoineides with the difference hetween the homan and the British Empires.

The self-Governing Dominions have become selfgoverning, beeamse self-govermment is inherent in the British ralce; the grant of self-grovermment to these British communities hats, therefore, been in the course of nature. This note rums through lorel I) rham's report. He proposed to grive self-government to the French Camadians only as part of and merged in a British nationality. Even if the French and Dutch were not, as they are, beingr white and western nations, infinitely more akin to the English in political views and traditions, than any coloured people of the Empire, there is the firet that in Camada the British element outnumbers the French, and in South Africal is on an equality with the Duteh. 'Therefore, in the present Self-Governing Dominions it may be sald that self-govermment is the result of natural evolution. But India - to take the greatest and in the work of construction perhaps the most advaneel of the British dependencies-never has been and never will be made British hy settlement. If it were to be plateed in the catengry of selfgoverning peoples, it would be placed in a category to which it does not naturally belong, and it womlel be endowed with entircly alien institutions, which for many generations to come would be hardly 
intelligible, much less beneficial, to its millions of inhabitants.

Further, the above argument assumes what many authorities have warned us is not and never has been the case, that India is one, instead of being the home of the most diverse races, creeds, classes, and sorts and conditions of men. In Lord Durham's report self-government was to be the concomitant of union, and responsible government has attained or is attaining its fullest expression in groups of kindred communities, made or being made by union or federation into larger wholes. Such unity as there is in India has not sprung from the people or the soil. It is the result, as the Roman Empire was, of all the diverse elements being controlled by one alien rule, which has produced, again to quote Professor Bury's words applied to the Roman Empire, 'a merely external union.' If self-government were granted to India, this bond of union would largely disappear, and the diversities would prevail. It would be impossible to estimate how many generations must pass away before union, which must be the basis of self-government, can come from below not from above, from within not from without.

India, which perhaps of all parts of the British Empire is most nearly akin to a Roman Province, has been taken as the British dependency which is on the highest plane. It is on the highest plane, partly because there has been in this great Eastern 
land a civilization unknown to negren or Pacific lands of barbarism, partly becallse british constructive administration hats here been longent at work, and hats found its widest and fullest field. But the fact that India, or piut of India, hais been the home of a civilization of its own, dues not necessarily make it a more promising area for future self-government. The eonservatism of the East is proverbial, and lanels which have known no government at all, other than barbaric usage, may enceivably be a more congenial soil for planting alien institutions than one which possesses a system or systems deep rooted in the pisst.

British constructive administration in India hats been suceessful, not as having brought in political institutions of a British type, but as having bettered what was in Indial alreaty, thit is more or less personal rule. It his given what was and is meler. stood, and not a House of Commons, which would not be unelerstoul. Self-gorermment implies the many, not the few; and it is not mntil the many have in the long course of ages heen wholly transformed that the sphere of rule cam be assimilated to the sphere of settlement, though the fiew maly be and are being increasingly associated in the work and traning which rule implies.

It is then roughly true to saly that the British Empire is two Empires in one. Let us smppose, hy way of further illustration, that the Empire consisted only either of the sphere of settlement or of the 
sphere of rule. Could we in either case find analogies? If there were no India and no Crown Colonies and Protectorates, the British Empire would consist of the United Kingdom, Canada, Newfoundland, Australia, New Zealand, and South Africa, forming a group or federation of self-governing communities, linked together in partnership under one Crown, and having in the United Kingdom a predominant and to some extent managing partner, for the reason that the United Kingdom is the ancestral home of the common King, that it formerly ruled the other partners, that it is the Motherland, and is still, though in a constantly decreasing proportion, far ahead in strength, wealth, and population. There is no analogy to be found to this political association, either in the Roman Empire or in any other ancient or modern Empire. At first sight, to compare great things with small, there was something resembling it in Greek history, in the famous confederacy of Delos, which started as a League of Sea States of kindred blood and origin, with a predominant partner in Athens, the league being formed for common defence purposes, and the partners contributing, some in money and some in ships, while the executive control was left in the hands of Athens as the predominant partner. If we could forget how the Ionian confederacy began and how it ended; if again the question of Naval Defence was, even more than it is, the all-absorbing question of our Empire; and if the Self-Governing Dominions 
left the control of their ships wholly in the hands of the Admiralty, we should find some paralled between the two cases. But this Greek league began with members which were entirely independent States, and ended with members which were tributary subjects of Athens. Our system is composed of units which have been steatlily growing from subordination to equality and partnership. We cannot find analogies to the British Empire in Greece, because all the Greck colonies started as independent States. The Roman Empire gives us no parallel to our sphere of settlement, becaluse its history is a history of talking awaly, not enlarging freedom. Nor does modern history give us anything with which to compatre Great Britain and her colonies as opposed to her dependencies. We must comfort ourselves with having, for better or worse, presented the work with something wholly new.

If, on the other hand, we eliminate the selfGoveming Iominions, if the British Empire at the present day consisted solely of India and the Crown Colonies and Protectorates, we should lave the case of a comparatively small but strong nation ruling absolutely territories and peoples in size and numbers out of all proportion to itself. The population of the United Kingdom at present far exrods the combined populations of the Self-(roverning Dominions, but it is small as compared with the population of India alone, leaving out of sight the Crown Colonies and Protectorites. Now so fiur ats the keynote to this 
side of the Empire is rule, we are coming somewhere near to the Roman Empire, and there is this interesting point to notice. The world grew upon the Romans, says Bacon. It did so, in one sense among others, that the acquisition of Provinces called out the strong qualities of the Romans and made them stronger. They became rulers because they had to rule ; the Provinces were their training ground, and the Western Provinces bred new rulers for the Empire. Similarly every part of the world, where British dependencies have been acquired, has been a training ground for British administrators, and traditions of rule have grown up and been handed on. We have good reason for thinking that England has done much for India, but she has also gained much in possessing in India an unequalled school wherein to learn the lessons of responsibility and administration. The Romans and the British alike had an innate capacity for ruling, which grew by use; but we have seen that the field in which this quality was applied and trained was very different in the two cases. In modern times, perhaps, the nearest analogy to Great Britain and her sphere of rule would be the Dutch and their colonial Empire, both Great Britain and the British dependencies being on a larger scale than the Netherlands and the Dutch dependencies. It would be the nearest analogy-though far from near-because in either case trade has been the ultimate cause of the acquisition of dependencies. With the Romans, 
conquest brought trade in its tran, and where the Romans conquered and where they trated, there they formed colonies and they ruled. With the English, trate begat acquisition of territory, and where the English trated and where they acpuired territory, there they med. But in the sphere of rule, they did not form eolonies, for British settle. ment in the West Indies is an exceptional case. Nothing conlel be more remote from the militay colonization of the Roman Empire.

The question asked at the begimning of this ehapter was, 'How fill was the Roman Kmpire, and how far is the British Empire, one Empire?' 'The answer is that the Roman Empire wats one, that the British Empire is two in one; that each of the two halves of the British Empire contains the mont diverse clements ; that one half is a politieal structure which has no common ground whatever with the Roman Empire and camnot be compalred with it in any way; that the other half admits of rompanison but still more of eontrist. 


\section{CHAPTER X}

THE BRITISH INSTINCT AND THE LAW OF NATIONAL LIFE

How did the Romans hold their Empire for so long a time? How has the British Empire been lield together up to date? And by what means, judging from past experience, and from the signs of the times, are we likely to continue to hold it?

The answer to the first question has been abundantly given already. The Roman Empire was held by force, supplemented by assimilation, the nucleus of which assimilation was in the Roman colonies. It may be emphasized once more that the Romans used force so effectively and so continuously that they placed their Empire beyond the possibility of competition. It became not the strongest or greatest in a group of competing kingdoms, nations, or Empires, but for centuries practically the only Empire. According to the view which each student may take, it may be said to have lasted so long because it had killed out competitors, or to have decayed for want of competition. At any rate, the only civilized power which the barbarians living in the outer darkness had ever known or heard of was the Roman power. 
There was no other power with which they conld compare it.

In British history overseas much has turned and still turns, in many and different respects, on knowledge or want of knowledge, on ability or inability to compare. This can be illustrated on various sides, all of them interesting though not all germane to the subject of this chapter. In North America the relations between the colonies which now form the United States and the Mother Country suffered greatly because, communieation being in the seventeenth and eighteenth centuries relatively worse than it was in the Roman Empire, the colonists did not at any given time know what Great Britain was doing at the other side of the world. They saw British mistakes under their eyes, but Marlborough's victories which, ats a matter of fiact, brought the Treaty of Utrecht and assured British possession of Nova Scotia, Newfoundland, and the coasts of Hudson Bay, being remote from them, were not compared with and weighed against fidilures in America. When the American War of Independence came on, the French Canadians, a lately conquered people and strongly attalched to France, did not, with very few exceptions, rise against Englind, though invited to do so by the revolting colonies, lingely because they had had opportunities of comparing the English from home with their English neighbours and former enemies in Americil. They did not want the English in any form, but of the two types they 
preferred the English from England. At the present day the negroes in the West Indies compare favourably their own status under England with the status of the negroes in the United States; and this comparison means a strong attachment to England in the black population of the West Indies. Take again the case of India. The natives of India only know British rule. They would probably appreciate it more fully, had they been able to compare it with other alien white rule. Where British rule is side by side with other European rule as in West Africa, there are clear indications that the native races prefer British rule. England, in her relations with native races, has gained greatly, not from the fact that the English are popular as a race, but from the fact that wherever there is a possibility of comparison, at any given time or place, some other people is usually found to be more unpopular. This feature did not enter into the Roman Empire, because it had no competitor, and because its basis openly and avowedly was force.

If the Roman Empire was held by force, how has the British Empire been held together up to date? Again, let us take separately the two separate halves of the Empire-the sphere of settlement and the sphere of rule.

The Self-Governing Dominions and the Mother Country have so far been held together, by starting, in the main, from a common origin, by allegiance to a common Crown, by the sentiment which a common 
origin and a common allegiance hats created and preserved, by substintial advantages aceruing to the Dominions from their connexion with the Mother Country, mainly protection from foreign enemies, and the supply of eapital for purposes of development ; and over and above these bonds of union, by the constant removal of restrietions on liberty and the stealy encouragement of larger units. The policy which has produced existing conditions in the self-governing half of the British Empire originated in Lord Inrham's report, and the essence of that report was that self-govermment is in British or Anglicized communities the basis of content, though the self-govermment which he sketched out for Camada fell very far short of selfgovernment as we know it at the present day; that self-government should be preceded or aceompanied by union of coterminous Provinees into one larger whole; and that this double process of giving freedom, and grouping into larger units, not only would be, but should avowedly be, in the interests of the Mother Comntry as well as of the colonies; that it is, and should be recognized as, the one and unly road to unity of the Empire.

'The key-note of Lord Durhamis report and of the policy to which it gave rise, wats constructiveness. Constructiveness has been characteristic of the British as of the Roman race, hut the constructive genius of either race has shown itself in different ways. The Romans set themselves to build up one 
Empire on a despotic model. To make the one whole, they kept the parts divided, in order to concentrate strength at head-quarters. The English for the last sixty or seventy years have set themselves to build up nations within the Empire. They have taken the method of devolution, and made the parts into larger units, thereby giving them greater strength relatively to the centre. The success in doing so up to the present date has been due to greater continuity in this respect than has always been apparent in British history overseas. It has been pointed out in a previous chapter that the Romans were far superior to the English in continuity of policy, and that want of continuity has been the chief failing of the English in the matter of their Empire. It is difficult to dissociate a Government from a people. The kind of people produces the kind of Government; and party Government in England, which is at the root of any want of continuity in policy, is the product of English love of freedom. But, so far as Government and people can be dissociated, want of continuity in British colonial policy has been due to the Government rather than to the people; and in giving freedom to the younger British communities of the Empire, and creating or encouraging larger units, there has for once been continuity of policy on the part of successive Governments, with the happiest results up to the present time. It may be summed up that the United Kingdom and the Self-Governing 
Dominions have been held together "Ip to the present time, because, apart from what mat be called temporary sources of irritation, there hats been no substantial reason why any of the selfGoverning Dominions should wish to part from the Mother Comitry and leave the Empire, and there have been substantial reasons why they should not want to leave it.

The dependencies of Great Britain, as oppesed to the Self-Governing Dominions, like the Romin Provinces, have, speaking generally, been held by force, open or in reserve, but by force perpetually receding into the background ats good govermment has produced good will. At the risk of vain repetition, the main features of the story of Great Britain and her dependencies, ats opposed to the Self-Governing Dominions, may once more be stmmarized as follows.

Trude hils bred conquest, and eonquest hats developed into rule. Similar stages cam be traced in the overseas history of other Europein nations; but beyond the seas, ats at home, in spite of much want of continuity of policy, and in spite of a mischievous chanacteristic of Englishmen at home to assume that the laws and institutions which are good for Englishmen in Englind must neeessarily be good for all other races under all other conditions, there has been more growth and evolution in British history than in the history of any other power with which Great Britian might be eompared. $16: 3$ 
There has been much going backwards and forwards, greatly to the detriment of the subject races as well as of the dominant people, but on the whole there have been few violent breaks in the history, just as there have been few eras of meteoric brilliancy. The English did not overrun a world or a continent as the Spaniards overran Central and South America; nor did they rise from being traders to be conquerors and then sink back again. By holding their own, they gathered round them more than had been their own, and in every quarter of the world where the English have gone, there has been, over and above their great contests with other European nations, a gradual widening of the British sphere either by a series of small wars or by more peaceful means.

It has already been noticed that to the work of ruling the dependencies so acquired the British character has not brought any special power of assimilation. British citizens who have gone among coloured races have lived more outside them than has been the case, for instance, in the dependencies of the Latin peoples. This has been a source of strength rather than of weakness, not only on the assumption that the sphere of rule is to remain a sphere of rule, but probably also if the ideal of the future is that the sphere of rule is eventually to broaden out into something more than a collection of subject dependencies; for it must be counted as a gain that there is no apparent likelihood of self- 
governing eommmities coming into being on any great scale in the British Empire of the type to be found in certain parts of Spanish Americal, where hybrial populations handle democratic machinery with little result heyond constint revolutions. What the British eharater has contributed to the task of ruling is honesty, as men go, and the instinet of filir platy, common sense, and pratetical constructiveness. The success which Great Britain has attained in dealing with her dependencies hats been mainly due to the combination of the strong haud with honesty and justice. She has given to them from without what they hatd never received from within, security for life and property, justice betweon man and mam, immunity from extortion, law insteal of cinprice. Common sense hats made against violent elnanges, so that the English, like the Romans, have on the whole dealt gently with and turned to good account native customs and institutions; and British constructiveness, as shown in public works, has brought before the eyes of the ruled unmistakible evidence that they have derived material advantage from the rulers. The ruling faculty is in filct the highest phise of constructiveness. 'The trader evolves into the ruler becallse the making instinct in eertilin races is not satisfied by merely making money.

Lastly, it will be noted that in the sphere of rule, as in the splere of settlement, this instinct or quality of constructiveness is promoting larger units. If we 
look at the Far East, we find the British dependencies in the Malay regions, including Borneo, more and more being grouped round or linked to a common centre at Singapore. If we turn to the West Indies, we find a growing tendency to some form of federation. If we take the case of West Africa, we find that all the Niger Territories and Lagos have lately been consolidated under one Government.

So far for the two halves of the Empire taken separately up to date. One half has been held to Great Britain as being the Mother Country, the other half has been held to Great Britain as being the ruling country; and, inasmuch as the two halves have remained mainly, though not wholly, aloof from each other, the link of Great Britain has kept the Empire one. But in turning from the past and present to try and decipher the future, we are met on the threshold with the forces of science and the fact that under our eyes they are changing and modifying our Empire. It is idle to speculate as to when distance will become a negligeable quantity, or whether and to what extent medical skill will transform the sphere of rule into a sphere of settlement, but one thing is certain, and that is that the two halves are for good or ill coming into constantly closer relations with each other. It will be well to consider the future, as we have reviewed the past, with respect to each half separately; but it must be borne in mind as regards the future, that the problem may be not whether the Self-Governing Dominions 
will remain with the United Kingdom, qui the United Kingdom, but whether they will remain with the United Kingdom plus her dependencies. In other words, it is conceivable, though mont unlikely, that England might at some future date have to choose between her sphere of settlement and her sphere of rule. This point will be further noticed below.

Taking the sphere of rule first, how will it be retained? The answer is firily simple. As firr as can be judged, it will be leld simply and solely by the same means that have been hitherto employed, by good government with the strong hand behind it. It must, at the same time, be recognized, that being held on these lines and by these methouk, the dependencies have been, or are being, more or less transformed. Good government and constructive work has meant not merely multiplying numbers by giving security for life and facilities for living. but also raising the status of peasintry or tribesmen, who before the advent of British rule were held of little or no account, linking up tribes and States and prineipalities into larger units, intellectual and moral development, and the partial substitution of British civilization for other rivilizations or for many types of batrbarism. As in the sphere of settlement, so in the sphere of rule, the policy of Great Britain hats been the reverse of the Divide et Impere prolicy; but whereas in the sphere of settlement British methols have resulted mainly in broadening and enlarging 
without transforming, in the sphere of rule they are resulting to some extent in making something different in kind. New conditions, bringing in their train new problems, are being evolved to a greater degree in the sphere of rule than in the sphere of settlement, and science is setting itself to modify the effects of climate. Still, as has been pointed out in the last chapter with regard to India, the greatest British dependency, we have to look very far ahead to contemplate seriously a time when the dependencies of Great Britain will cease to be in the true sense dependencies; and it may be safely concluded that if the British Empire simply consisted of Great Britain and her dependencies, it would be held together as long as, and no longer than, Great Britain retains her strength.

When we turn to the Self-Governing Dominions, there is no such simple answer to be given. There are two preliminary comments to be made, sufficiently obvious but not always sufficiently regarded. Aristotle has told us that the objects of revolutions are great but the causes or occasions of them are small. $^{1}$ It is these apparently small causes or occasions, originating with individuals rather than with Governments, which are most likely to make or mar the Empire. The individual had more to do than Government with making our Empire, and the individual will probably in the long run have more to do with keeping it. It is not statesmen who are

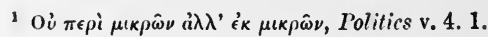


going to have the final say as to whether the British families are going to come closer to one another or to drift further apart. The ultimate decision will rest with the men and women who make up the different British families, who live everydiy lives, and are guided not so much by high state policy ats by instinct and common sense. It is, therefore, a very great and real mistake to regand the future of the Empire as depending in the main upon Ministers and Government offiees. It depends in an increasing degree, as distance diminishes and knowledge grows, upon the individual citizens.

It is also a great mistake to argue in regard to the problem of Empire as though men and women, and communities which are made up of men and women, did not act, as they do almost invariably act, from mixed motives; to lay down that sentiment is the one bond of Empire, or that the Empire wholly depends upon commercial interests, and so forth. What holds the Empire together and what will hold it, if it is held, is an aggregate of considerations, one of which will perhaps be predominant at one time and in one community and another in another, but none of which will hold the field exclusively.

Now, having seen how the Inminions and the Mother Country have so firr been held together, let us ask what motives are there likely to be in the Dominions for separation from the Empire and what motives for remaninge in it. 'The matin motives for' separation will be twofold, one more sentimental 
than practical, the other purely practical. The first will be the increasing and perfectly natural desire, which grown up peoples feel as strongly as grown up men, not to be subordinate even in name, to control their external as well as their internal relations, to be sovereign peoples in the eyes of the world. The second and practical motive is, or may be, the desire not necessarily to be involved in all the liabilities of the Mother Country, partly on financial grounds, partly from fear of in any way compromising existing autonomy. There have already been indications that a Dominion may not wish, when the Mother Country is at war with another power, necessarily to take an active part in the war, unless the war is to some extent of its own making and on its own behalf. Similarly, in the early days of the old American colonies, the New Englanders tried to make a treaty with Canada on the terms that they should remain at peace even though England and France were at war. With regard to this second motive, however, it is specially important to bear in mind the point which has already been emphasized, that the Self-Governing Dominions must not be treated or thought of as one in their relation to the Mother Country. Nor must it be forgotten that party Government holds the field in each of these Dominions as at home, and that, therefore, the views of one Government even on Imperial questions may be utterly different from those of another. The dominant feeling in one 
Dominion at a given time may be to stand outside the liabilities of the Mother Country, and in another not to stand outside them so much as to have a voice in determining them. It is perhaps roughly true to saly that the first of the two motives given above, the sentimental dislike of the appearance of subordination, operates, or is likely to operate, quite ats strongly in the more purely British eommunities at in the more mixed communities; but that in the ease of the second motive, if we allow for party government and the divergent views of Liberal, Conservative, and Labour parties, and try to strike an average, the more purely British communities are likely to be less desirous to stand outside the liabilities of the Mother Country and more desirous of full responsibility and partnership than the mixed communities. Where there is a strong French Canadian element or a strong Americin element as in Camada, or a strong Duteh eloment as in South Africa, there must naturally be, in a section of the population, a tendency to aloofness from liabilities which do not directly concern the part iculatr Dominion.

'Taking the other sille of the aceomnt-the motives for remaining within the Empire-it may fairly be said that, even leaving out of sight the present undoubted value of the British comnexion, communities, like individuals, however democratie, have a strong strain of Conservatiom in them, and, mnles: some very special oceasion arises or some very 
obvious gain is in view, they are slow to break entirely with the old order. Moreover, special occasions which make for union are as likely to present themselves as special occasions which make for division. At the present time, for instance, the foreign competition which threatens England's sea power is a strong stimulus to Imperial unity. Gratitude and good feeling again have weight in collections of men as in each individual man, and the British record towards the Self-Governing Dominions of the Crown is a bright record, which cannot be matched in history, of liberal and generous policy. The call of the race is strong, wherever the citizens are of British descent, and the mere sense of established nationhood in the Dominions may, and probably will, in a manner to be referred to later, make for the permanent continuance of the Empire.

If we balance these two sets of motives against each other, the path of salvation obviously lies in a continuance of the constructive policy of which Lord Durham was the pioneer, and which has so far proved successful. There is no other alternative; we have gone too far in one direction to think of turning back; we have created nations, and cannot uncreate them. We can only recognize and welcome existing conditions and move forward again.

It has been said that the Romans and the English have shown in a marked degree constructive genius; that the Romans, on the one hand, while giving much 
scope to municipal life in the separate provinces, were always intent on strengthening the eentre, while the English, on the other hand, have applied themselves to building up the parts. Possibly it might be diflicult to maintain that the constructive genius of the English has been actually greater than that of some other modern peoples, of the French, for example; but, at least, British constructiveness has had a character of its own. In creative work the British instinct has shown itself in the absence of a hard and fist system; in the rejection of schemes involving all or none; in the realy acceptance of compromise; and in favouring evolution, growtl, and development as opposed to complete novelty. British history tells us that whatever has been permanent in the work of the English has been the result of evolution from the past, not of breaking with the past, and that the English have built woll because the builders have accommodited themselves to the times and the plates and have not been hampered by elaborate plans, designs, and surveys drawn ont beforehand by the Govermment.

In considering the future of the Empire it appears feeble and inconclusive not to sketel out a definite programme and to preseribe new machinery. Consequently we have a plethora of plans and schemes. But it is in the very attractiveness of schemes and programmes that the danger for the futme ronsists. 'The British present has grown up on no definite plan. So fiu from being logieal, it is a mity of 
contradictions, absolutely impossible on paper, but working very comfortably in fact. To anything like an orderly ground-plan of the future, British instinct, which constitutes British genius, is opposed. It is equally opposed to the all or none element, the absence of compromise which all schemes and plans usually imply. Clear and practical views are constantly obscured by the wholesale character with which both the supporters and the opponents of schemes invest them. There is only one sure guide to the future, and that is the race instinct which represents day to day opportunism.

What does continuance of a constructive policy mean? What is there left to construct? On the one hand, the process of strengthening the parts in relation to the centre can be carried on. Nationhood can be further encouraged among the young peoples of the Empire by constant recognition, as occasion offers-and occasion is constantly offering, the object being to eliminate as far as possible the first of the two motives for leaving the Empire, which is the sense and appearance of subordination. On the other hand, the future seems to call for some growing organization which will link the Mother Country and the Dominions each with each on terms of equality in lieu of the discarded terms of superiority and subordination. But this organization is well on its way in the form of the Imperial Conference, supplemented by subsidiary conferences for the discussion of single questions; while the calling 
into being of a Standing Committee of Imperial Defence presents obvious ficilities for the development of Imperial co-operation. Nothing could be more in harmony with the British instinct and British methods of construetion, thin the evolution of the Imperial Conference and its concomitants. Twenty-five years have elapsed since the first meeting of the kind took plitee without any system of any kind or any rule as to representation, and at the present moment the Imperial Conferenee is at welldefined, fully understood, and fully recognized machinery, the meetings being held at stated intervals, and each meeting resulting in a step forward in the direction of Imperial unity. The wonder is that it hias developed so rapidly, not that it has not developed further, and any attempt to stimulate its growth by hothouse methods would be disastrous. It would be disastrous, because it would run eounter at once to the British instinet and to what has been described above as the second motive for leaving the Empire, the dread of being involved in external liabilities which would not be removed at the present stage of development by having one voice among several in the direction of a common policy. The diversity between the Dominions, and the operation of party (iovernment in each Dominion, makes for different views in regard to an Imperial Comncil of one kind or another. It is, on this ground alone, not only inexpedient but absolutely impossible to build up the future except by slow degrees, if the 
building is to endure. The more the parts are strengthened in relation to the centre, the more they recognize their strength, the less they will fear that autonomy will be injured by closer partnership.

When we turn from the question of political organization to that of commercial relations, we find the young peoples on the one side and the Mother Country so far on the other. Preference and Protection commend themselves to the young peoples, whereas the present generation in England has grown up under Free Trade. It is often suggested that the Dominions might under certain circumstances or for certain reasons wish to part with the Mother Country; but since we have outgrown the old Whig doctrines, there are few who suggest that England might wish to part with the Dominions. In fact it is probably true to say, though it may not be generally admitted, that as each succeeding year adds conspicuously to the population of the young peoples of the world, whether inside or outside the British Empire, the value of the Dominions to England increases in much greater proportion than the value of England to the Dominions, because each year each Dominion comes nearer the time when it can defend itself, and each year England, without the Dominions, tends to be more outdistanced in population and home resources by some of her foreign competitors. Nor does this statement exhaust the case. It is not merely a question of quantity, it is a question also 
of quality and of kind. The ascendancy of Europe in the world, of Old World methods and standards, is no longer unchallenged. The future is largely for the 'New Model' among peoples, and in the competition of the future it is all-important for England to have by her side British peoples built, for better or worse, on the New Model.

From this it follows that if England is to hold her own ats at nation, she must keep the Dominions with her; and if she can only keep then with her by paying a price, the price must, if possible, be paid. Imperial Preference, therefore, cannot be regarded simply ats an economic question. On the other hand, if the price is too high for the English to pay, they cannot and will not pay it, whaterer may be the result, and may elect to part with the Dominions. But ats the Dominions do not intend that the ties of Empire shall impede their own development, so they make no claim whatever that any step should be taken by England which should militate against the welfare of her people at home. The whole question is obscured by, and the whole dimger to the future lies in the lust for a wholesale scheme and the desire of extreme Free Traders to saddle their opponents with a wholesale scheme. Again, the one and only safe guide is British instinet and readiness for practical compromise. It is not a case of all or none. Imperial Preference, ats has alrealy been said, is quite natural, more natural tham Free Trade. Further, it is one of the many cases in 
which appearances are valuable. In the absence of any substantial preference being given, a definite indication of readiness to give preference to peoples within the Empire as against peoples without the Empire, so far as such preference will not be substantially detrimental to the Mother Country, would be of great effect. It is as necessary to reject the doctrine that to give better terms to our own peoples than to foreigners is unsound in principle, as to be cautious with regard to any novel and wholesale scheme. Imperial Preference is the goal to be aimed at. Little by little is the way to the goal.

British instinct, the instinct of wise opportunism, is the one and only safe guide to sound relations between the Self-Governing Dominions and the Mother Country. But we now come back to the point that the relations are not merely between the Self-Governing Dominions and the Mother Country, but between the Self-Governing Dominions (all different) on the one side, and on the other the Mother Country plus the dependencies. The possession by England of great tropical dependencies with multitudes of coloured British subjects already gravely complicates the relations between the Mother Country and the Self-Governing Dominions, and, as has been seen, is likely to complicate them still further, as coming and going increases, and makes the colour problem a continuously increasing difficulty. On the other hand, the existence of these British dependencies may, and probably will, 
be found to supply the strongest of all motives to the Self-Governing Dominions for remaining within the circle of the British Empire. The Self-Governing Dominions are respectively building up their national structures and their national life, but the nearer they come to maturity and the more they become conscious of having dene their necessiry work at home, the more they are likely to value partnership in a greater whole. It is a law of nations, writ large in history, that when they have completed the home edifice, rounded off the corners, and given it final form and shape, the constructive instinct seeks for new outlets beyond the seas. The colonial Empires of European nations followed on the achievement of national unity at home. Spain, Portugal, Holland, France, Great Britain, all in turn obeyed the law. United Italy has acquired possessions in Africa, United Germany has felt increasingly the call to colonial expansion and Empire. Even the United States have not kept within the limits to which they have applied the Monroe doctrine, and that doctrine itself, in its latter-day phases, is little less than a claim to a Protectorate far beyond the actual boundaries of the great Republic. The younger nations of the Empire are not likely to be exceptions to the rule; and if they, too, must find an outlet in their turn, how ean they find it but by retaining their British citizenship and entering into the heritage side by side with the eitizens at home? Or even if they could find it 
otherwise, what opening would be comparable in greatness and in worth to that which the British Empire offers? The fact that under existing conditions the Self-Governing Dominions have such scope for future history, and that they would lose it were the present supremacy of the Motherland to be wrested from her by foreign rivals, may well, in an increasing degree, make the sentiment of kinship, which is patriotism for the Empire, coincide with a sense of common interests ; and to young peoples, who look to the future, the possibilities of sharing greatness are likely to appeal with more potency than any dread of incurring liabilities. Meanwhile every citizen from the sphere of settlement who serves the Empire in the sphere of rule is a missionary in the cause of holding the Empire together; and the more openings that are found in the Imperial Services for the white sons of the Empire from beyond the seas, the greater will the number of such missionaries be, and the more it will be brought home to the younger peoples that it is worth while to stay in the British Empire. 


\section{INIDEX}

A.

Adeliticle, 16.

Africa, Northern, 34, 97 \& 1:,6.

Atriea, Tropical, i1), 100.

Afriea, Went. Ste West Aricat.

Agricolit, 60.

Algerial, 6.5.

Ameriean Colonies, Old, $i, 1: 7$, 168.

Anglo-Saxon federation, 110 11.

Appearances, importasen ot, 12430 .

Arueducts, 58, 62-3.

Arar (Saone), io.

Arnold's Reman Prorincial alministration, 65, 7., 91, 98: $114,127,12, \quad 1312,134$ atul $n, 135-6$.

Artesian bores, 66-7.

Asili, $68 n^{2}, 74,97,100,137$.

Assoluan Dam, $6 t$.

Athens, $104 n^{2}, 152-3$.

Angustus, 51, 59-9, 63, 73-4, 79. $102,133-4$.

Australia and Australians, 1. f, $15-19,34,40,44,47-9,66,70$, ง $0,92,103,106,12 \cdot 3,1157$, $15 \%$.

\section{l3.}

Bacon, Franej-, 33, 91, 96, 132?, 154.

Barbatos, 70, 114.

bermulis, 146.

Hoers, 13, 15 .

Borneo, 164.

boyce, sir R., fi.

Bristol, 76.

Britain, lioman Provinee of, 23, $34,37,60,115,140$.

British chatrateristics-

Assimilating qualitis, watut of, $127-30,162$.

Catpateity tor ruling, 60, 12x, 1 is 162,165 .
Constructivene-s, 149, 151, 1:4, $163,165,1702$.

Continuity of puliey. Want of, $4.5,875,160) \div$.

Individual initiative, $19,72$. $76-7,-3,-7,84-90,11213,116$ 166.

Instinct of olyortunisu, 171-2, 170 .

Liberal policy, 16:3, 16:, 170, Se. British Finpire -

Diversily in, 17, 42, (1)-6, 1001 , $116,1+1,145<173$.

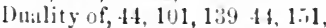
15 .).

Extent of, 61, 66, 140-1.

Family amalogy in, 2:3 31, 122.

Religion a tores in making, 7 . space an plement in, 1011 , $13-20,4: 3,5 \div$.

'lrate a torce in making. (i2. $76-7,22-9,154-5,161-2, \alpha c$.

British Colmmbia, 92, 119.

British tiuiana, 11?.

liritish North America, $37,44,5 f$. 119-20, se.

Britisls Nontl Anurica A.t of 1867,7 .

liruen, sir Dolvid, 67, 70.

burk", bilmumel, 4:.

Bury's Ilistury of the Later Roman limpire, $75 n, 78,102,1: 23$. 150.

l'.

Compagna, Ronnu, 69 aml 1 .

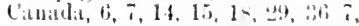

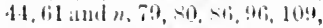
$116,21,14 \%, 145$ i $, 199,132$. $159,16 \div, 169$.

U1'l+1', 3s, s7 2 .

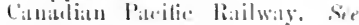
Ratilways in Camalda.

Citnall loeks, is 4.

('แแะls, 49-51, 6:'. 
Canals (continucd) -

Briare, 51.

Caer Dyke, 51.

Canadian, 52-4.

Chenâb, 64 .

Chinese, 49.

Egyptian, 49-50.

Foss Dyke, 51 .

Fossa Mariana, 51.

Georgian Bay, 53.

Irrigation, 49, 64 .

Isthmus of Corinth, 50 .

Languedoc (Canal du Midi), 51.

Manchester Ship Canal, 52.

Moselle-Saone, 50-1.

Nile to Red Sea, 50.

Panama, 49.

Ravenna, 51.

Rhine to Meuse, 51 .

Rideau, 53.

Roman, 50-2.

Sault Ste Marie, 52.

Suez, 49.

Welland, 54.

Xerxes', 50.

Carignan-Salières regiment, 117.

Chamberlain, Mr., 67.

Cicero, 59.

Citizenship, 44, 46, 90-6, 100-1, 107-9, 139, 177-8.

Civil Services, 82, 96.

Civitates Foederatae, 95.

Class distinctions, 91-2, 101-9.

Cobden, Richard, 27.

Colbert, 85, 117.

Coloni, 2 and $n$.

Coloniae (Roman colonies), 2, 4, $11-12,23,37,79,97,132$, 155-6, \&c.

Colonization, military, $14,80,117$, 155. See also under Roman Empire.

Colonization, Roman and British compared, 11-12, 16-17, 21-2, $80, \& \mathrm{c}$.

Colony, 1-5.

Coloured races and colour problem, 43-6, 62, 97-101, 103-4, $107,110-11,127,142,145-7$, $158,162-3,176$.

Commonwealth, 1 .

Communications, 32-54.

Companies, 81, \&c.
Companies (continued)-

Chartered, 81-9.

British East India, 83, 86.

British North Borneo, 86, 87.

British South Africa, 86 .

French, 84-5.

Hudson Bay, 86.

Imperial British East Africa, 86.

Netherlands East India, 13, 85 .

Netherlands West India, 85.

Portuguese, 84.

Royal Niger Company, 86.

Comparison of peoples, importance of, 157-8.

Competitive system, 100.

Cromer, Lord, Ancient and Modern Imperialism, $98 n, 127,128$.

Crown, the, 5, 7, 8, 86-7, 143-4, $152,158$.

Crown, Advisers of the, 144.

Crown Colonies, 5, 44, 135, 138, 148, 152-153.

Relations to Mother Country, 44-6, 152-5, 161-6.

Customs duties. See Tariffs.

Cyrenaica, 97.

D.

Dacia, 89, 115.

Dawson City, 56.

Delos, Confederacy of, 152-3.

Dill's Roman Society from Nero to Marcus Aurelius, $68 n, 103-4$.

Diocletian, 3, 133.

Distance and Empire, 32-49, 164.

Dominion, 1, 3, 5-8.

Dominions, Self-Governing, 5-8, $13,15,17-21,44,46,48,98-9$, $101,110-11,126,138,142$, 144-7, 149, 152-3, \&c.

Relations to Mother Country, $7,10,21-3,26-31,41-3,90$, $122,147-8,152-3,158-61$, $164,166-78$.

Dominium, 3.

Durham, Lord, and his Report, 14, 25-6, 36-7, 53, 79, 88, 110, $118,120,125,149,150,159,170$. Dutch, 13, 15, 51, 84-5, 149, 154, 177.

in South Africa, 13-15, 47, 146, 149, 169. 
r.

kigylt, $34,49-51,56,634,70,71$. $97,136,140$.

biluetricity, 49, 59. Selelentithly.

Emperor, lioman, 134 and $"$, $143-1$.

Empire, 1, 4, - 9, 7:, $89-90$, 124 5, 139. Sie also British Empire, lioman Empire.

Einuites, 102.

$$
\text { li. }
$$

Filkland Islitnds, 116, 14.

Family analogy. Sie british Empire.

Fiji, 145 .

France and the French, 15, 46. $51,-15,116-15,125,157,160$, $17 \%$

Free 'Iracle, $27,11: 121: 3,1745$.

Freelmen, 101, 1045.

Freeman's Mistorical ficogrupley of Eirrope, 115, 133.

French Canatians, 1415,467 , $118,143,146,149,157,169$.

Friedlinder's Romen Life and Manners wmed the Litrly Empire, 57, 73.

Fuller, sir Bampfylile, 64.

ii.

Gaul, 16, 23, 37, 137 .

German Legion in south Afrieat, 80.

Germany, 17\%.

Gibbon's Decline and Fill, 33, $57-8,61 n, 69,94,113-11$.

(iibraltar, 140, 14s.

Governors, 134-5.

(ireece and the (ireeks, $22,65,92$, $115,132,152-3$.

11.

Haldimand, Leneral, 5:3.

Harcourt's livers umel C'unals, is.

Haturan, the, 65.

Heitland's Rounu Republic; 72-4, 81.

Holland. See Datel.

Iluctson Bay, 157.

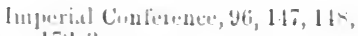
$17: 3$.

(i) nncil, 173.

befence, standing Committere of $17: 3$.

l'reference, 1:2, 1746.

sorvices, 178.

Imperialism, $27,301$.

Inperimm, 4, $5,9,1 \% 4$.

Indentured coolie system, 14.

Inthia and Indians, 4, $2,21,40$, $44,45,60,61-2,64,70,74,77$, $86,-9,96,97,99,100,107,135$, $143,145-54,15,165$.

India, Colunization from, 14:.

Interinetation Act of $1-89,1,4$.

lonian Coufuleracy. Set Delos.

Irrigation, 5s, 63-7.

lally and ltalians, 3, 12, 33, 87, $39,56,71,79,93,17$.

\section{J.}

Jitmaica, 70.

Jowett, Benjatmin, Select pessentes fiom the Thoological Writions: of $77-8$.

Julius C'atesar: $: 10,73$.

li.

Kislgoorlie, sif, fii.

limberly, 56.

Koch, Dis, fit.

1.

l.abour and Lillour Panty, 102 9, 169.

Labour guilds in lioman Empire, 104 and $n^{2}$.

Latin peoples, 1:2 \&, 162.

latverin, 67.

lewis, Sir lieorge Conewall, fioverument of Inepulemies, $32,1: 45,131$.

libyan Desert, 6i.

Iaster, Lord, 67, :I.

livingstone, 1)awil, 7..

Lomion, 36, 35, 40, 7., 7t5. 
M.

Macdonald, Sir John, 6, 120.

Machinery, substitution for handlabour, 56-7.

Maine, Sir Henry, Ancient Law, 92.

Malaria, 68, 70 .

Malaya and Malays, 100, 148, 164.

Malta, 70, 140.

Manson, Sir Patrick, 67, 68.

Maoris, 99, 145.

Marius, 51 .

Marlborough, Duke of, 157.

Mattingly, H., The Imperial Civil Service of Rome, 137.

Mauretania, 34, 97.

Mauritius, 148.

Medical Science, 67-71, 164.

Mediterranean, 33, 34, 50, 136, 145.

Melbourne, 16.

Merivale's History of the Romans under the Empire, 16, 39, 60.

Mines, 55-6.

Mithridates, 74 .

Mommsen's Provinces of the Roman Empire, 50, 63-5, 137.

Monroe Doctrine, 177 .

Montreal, 14, 53.

Mundaring reservoir, 63.

Municipal government derived from the Romans, 95.

Municipia, 97, 132.

Munro's Seigniorial System in Canada, $117 n$.

\section{N.}

Nationality, 108-11, 119-21, 149, $170,172, \& c$.

Native races and problems. See Coloured races.

Naturalization, 94-6.

Naval Defence, 28, 152-3, 170.

Navigation Acts, 121-2.

Negroes, 91, 98, 151, 158.

New Zealand, 7, 15, 18, 49, 99, $145,152$.

Newfoundland, 5, 8, 76, 145-f; $152,157$.

Niger 'Territories, 164 .

Nile, $50,56,64-5$.

Nismes, 62.

Nova Scotia, 146, 157.
0.

Ottawa, 53.

P.

Pacific races, 100, 151.

Parkman, Francis, Old Régime in Canada, 116-17.

Party government, 88, 160, 168-9, 173.

Pasteur, 67.

Patria Potestas, the, 23.

Pelham's Essays on History, 2, 69, notes.

Roman

Periander, 50.

Persians, 33, 40.

Plantation, 1, 2, 4.

Pliny, 59.

Pombal, 84.

Pompey, 69.

Pont du Gard, 62.

Population, 54-7, 78-9, \&c.

Portugal and Portuguese, 84, 177.

Possession, 1.

Protectorates, 95, 142, 152-3.

Provence, 63.

Province, 1, 5, 6.

Provinciae (Roman Provinces), 3, $6,11,12,17,34,37,59,63,69$, 74-5, 79, 82, 93, 131-2, 134-7, $150,154,161$, \&c.

Ptolemies, 50, 140.

Public works, 81, 163.

Publicani, 81-3.

\section{Q.}

Quebec, Town and Province, 14, $37,118$.

R.

Race, 92, 94, 96-101, 103-4, $106-11,115,122,170$. See Coloured races, White races.

Railways, 37-40. in Canada, 119.

Ravenna, 57-8.

Red Sea, 50, 56, 137.

Religion and Empire, 77-8, 96. 
Representative institutions unknown to liomans, $91,93,135$.

liesponsible government, $26-7$, $42,121,123,146,14951$ $159, \mathrm{sec}$

Richelien, $8 \%$.

livals, Romatu, 12,32 1,37 \&, ㅇ․ $5 \div, 60$.

lioman Empire -

Artificial cleation, an, 11316 , $123,134$.

Despotisn, a, 21, 23, 92, 101, $10 \times, 116,123,13: 2,135-6,141$, 153,15960 .

Extent of, 33-1, 61 and 1 , $100,136,140-1$.

Military chancter of, $2,: 3,12$, $32,59-61,73-5,79,92,94$, $108,115-16,123,13 ; 6,13<-9$, $155-6,155$.

'l'owns lasis of, 2, 11-12, 2ٌ1, 69, 75 ind $4,94-5,134$.

'Traders in, 59, 73-5, $81: 3,15 \%$ Unity of, $131-40,1434,150$, 155.

lioman law, 136.

lioman Wall, 61-2.

liomans-

Assimilative power of, 60,116 , $127-8,132,156$.

Capacity for rule, 21, 60, 68, $135,154-5,163$.

Constructive genins of, 50,5 , $62-5,159,170$.

Continuity of policy of, 8\%, 160.

Liberal policy of, 92-5, 115-16, $131,133,163,170-1$.

Military element in, 4, 1:, 19 , 61, 75, 79. And se' tumle' lioman Empire.

Not un alventurous people, 2 , $11,12,16,69,74$.

licligion not at personal fince among, 77-8.

lome, eity of, $33-4,37,57,623$, $75,93-5$.

Romniy Marsh, 65.

Koss, Sir R., 67-8 and $n$.

$$
\text { Si. }
$$

St. Litwrence river, $14,15,53$.

Scientifie inventions, 35, 11,48 , $52-9,63-4,66-71,161$.
Self-government. Seliogponsible government.

Senite und Srniturs, $10^{2}$ and $n^{1}$, $1: 4$.

Senecit's Iniuloyuer, 139.

Sicily, $114,137$.

slaves and slavery, 91-3, 92, 1035,107 .

slatping sickness, 68, 70 .

sunith, Adam, Wealth of Nutions, $1: 0,1: 1-2$.

South, liise of th+ 478,66 .

south $A$ frica, $13-15,1<, 19,28,44$. $47,6^{2}, 87,99,103,145-7,149$, $1 \% 2,169$.

Spatin and spaniards, $39,81,84$ $16^{\circ}, 172$.

Spunish America, 139, 163.

State, 1,6 .

steam and steam communication, $35,37-49,54,59$.

Stephan, lleinrich, $5 \pi$.

stokes' 'imstitution of the Britian colonies in Nonth Americe amel the Hest Imlie's, 3-5.

sillin, 7:3.

Sipurior, latke, $52,53$.

symonds, John Ailingenton, Shotelle's and studies in Itetly and Grewer, 62-:3.

T.

Tacitus, 3., 50 1.

Tillon, 117.

'Titrifls, 112, $1203,137-9,17 t-5$.

'laxes, larming of, 813.

lolergatiliy, 35, 39-10.

'Trule ane Empire. Sie listish limpira, Roman limpire.

'l'ratles Unions, 104, $105-9$.

'I'rajiın, 7:3.

'T'rinilat, 148.

'Tropieal dependencies atnel anministration, 415 , 701 , 91, $99-100,11 \%, \quad 146,1451$, $161-6,176$.

'Tropical diserases, tî- 71 .

U.

United States, 5, 29! 47, 49, 109$11,119-20,157,177$. 
V.

Victoria League, 90.

Virginia, 6-7 and $n$.

W.

Wakefield, Gibbon, 79.

War of Independence, American, 22,157 .

Warde Fowler's Rome, 12, 74, $104 n^{2}$

Water supply, 62-7.

West Africa, 71, 148, 158, 164.

West Indies, 70, 91, 146, 148, $155,158,164$.
Western Australia, 63, 66 .

Whigs, 26-7, 30, 112, 174 .

White races, $44,46-7,62,70,98$ $100,103,107-8,142,145,146$, $149,158,178$.

Y.

Yellow fever, 68, 70.

$\mathrm{Z}$.

Zimmern's Greek Commonwealth, $104 n^{2}$ 

THE LIBRARY

UNIVERSITY OF CALIFORNIA

Santa Barbara

THIS BOOK IS DUE ON THE LAST DATE STAMPED BELOW. 


\section{||||||||||||||||||||||||}

AA 000208280

University of California

SOUTHERN REGIONAL LIBRARY FACILITY

305 De Neve Drive - Parking Lot 17 - Box 951388

LOS ANGELES, CALIFORNIA 90095-1388

Return this material to the library from which it was borrowed. 
